Stratigraphy of the

Outcropping Cretaceous

Rocks of Georgia

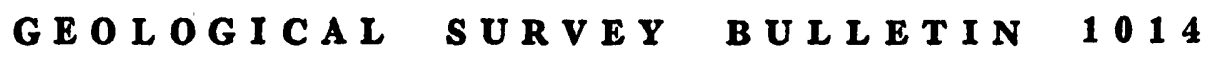

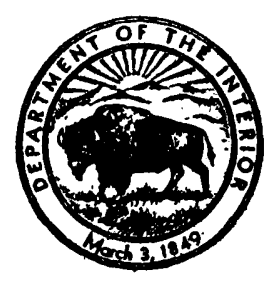




\section{Stratigraphy of the Outcropping Cretaceous Rocks of Georgia}

By D. HOYE EARGLE

G E O L O G I A L S U R V EY B U L L E T I N 1014

A study of the stratigraphy, structure, and geologic history of rocks that crop out in a northeastward-trending belt across the central part of the State

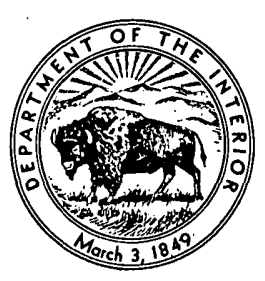




\section{UNITED STATES DEPARTMENT OF THE INTERIOR}

Douglas McKay, Secretary

GEOLOGICAL SURVEY

W. E. Wrather, Director

For sale by the Superintendent of Documents, U. S. Government Printing Office Washington $25, \mathrm{D} . \mathrm{C}$. 


\section{CONTENTS}

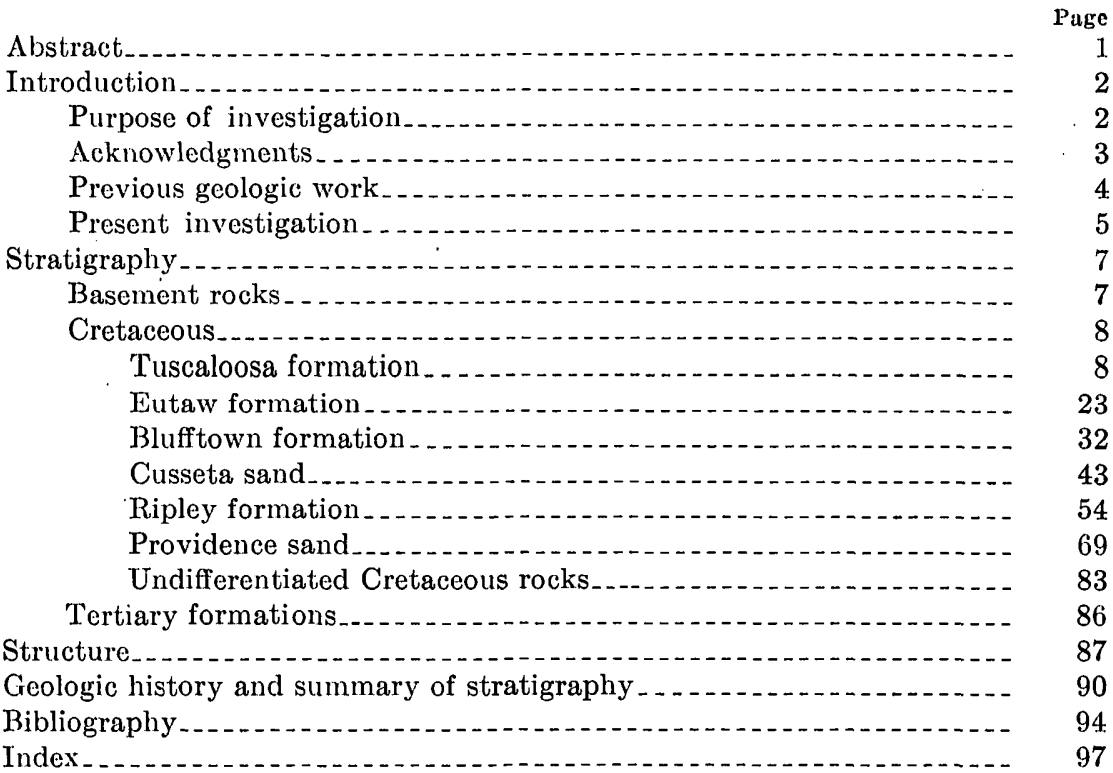

\section{ILLUSTRATIONS}

[Plates in pocket]

PLATE 1. Geologic map of Upper Cretaceous formations of Georgia.

2. Columnar sections of Cretaceous rocks of Georgia west of the Flint River.

3. Structure of Upper Cretaceous formations of western Georgia.

Figure 1. A. Downdip exposure of the contact of the Tuscaloosa and Eutaw formations. B. Updip exposure of the Tuscaloosa

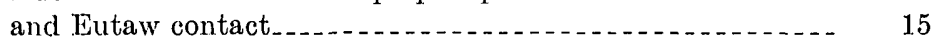

2. Fissile and brittle clay of the Eutaw formation . . . . . . . . 24

3. Clayey sand of the upper part of the Blufftown formation... 35

4. Massive dark-gray silty clay of the upper part of the Blufftown formation

5. Typical marine clay and sand of the Blufftown formation.....

6. Contact between the Blufftown and Cusseta formations at the type locality of the Cusseta sand..............................

7. Typical exposure of basal Cusseta sand east of the type locality -

age

2

2 
FIGURE 8. Contact of the Cusseta sand and the Ripley formation.......

Page

9. Fossiliferous dark-gray clayey sand of the Ripley formation...

10. Updip contact of the Ripley formation and the Providence sand.

11. Lower part of the Providence sand, near the bottom of Provi-

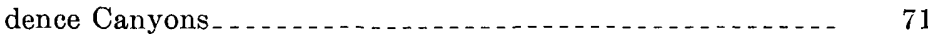

12. Downdip exposure of marine Providence sand . . . . . . . . 73

13. View of a gully on the Graddy farm, Quitman County ....... 75

14. Easternmost head of Providence Canyons_._............ 78

15. A spectacular gully, half a mile east of Providence Church... $\quad 79$

16. Generalized profile and structure section, Muscogee to Ran-

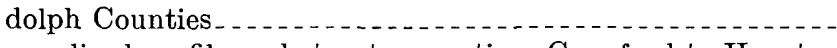

17. Generalized profile and structure section, Crawford to Houston

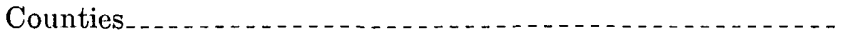




\title{
STRATIGRAPHY OF THE OUTCROPPING CRETACEOUS ROGKS OF GEORGIA
}

\author{
By D. Hoye Eargie
}

\begin{abstract}
Rocks of Upper Cretaceous age crop out in Georgia in a northeastwardtrending belt that narrows from about 68 miles in the Chattahoochee River valley on the west to about 22 miles in the Savannah River valley on the east. Locally in eastern Georgia the Cretaceous rocks are entirely concealed by overlapping Tertiary rocks.

The Upper Cretaceous rocks that crop out in the Chattahoochee River valley have been classified as six distinct lithologic units: in ascending order, the Tuscaloosa formation (the only nonmarine formation of the series), the Eutaw formation, the Blufftown formation, the Cusseta sand, the Ripley formation, and the Providence sand. Toward the east all these formations grade laterally into nearly similar beds of sand and clay. East of the Ocmulgee River these beds have not been differentiated into formational units.

The Tuscaloosa formation consists mostly of sand, generally coarse to gravelly and arkosic, but contains subordinate amounts of mottled clay and silt. In the Chattahoochee River valley the formation is about 250 feet thick, but the upper part is overlapped by the Eutaw formation toward the east so that only about 40 feet of the Tuscaloosa is exposed in Bibb County. East of the Ocmulgee River the Tuscaloosa so closely resembles the overlying Cretaceous rocks that no attempt was made to map it separately during the survey. The basal 30 feet, more or less, of the undifferentiated Cretaceous rocks for many miles east of the Ocmulgee River appears to be equivalent to the Tuscaloosa formation farther west.
\end{abstract}

The Eutaw formation in the Chattahoochee River valley consists of a basal bed containing coarse grains of quartz sand and other detrital materials as well as borings of Halymenites major. The basal sand is overlain by dark-gray soft shale interbedded with fine white sand. The shale contains abundant thin fossil shells. Toward the east the formation apparently becomes nonmarine and consists of pale-tinted sands containing a few thin beds of clay. The formation is about 125 feet thick in the Chattahoochee Valley, but it thins toward the east, possibly owing in part to overlap, to about 77 feet in Marion County. East of the Flint River the Eutaw cannot be differentiated from the overlying Blufftown formation.

The Blufftown formation in the Chattahoochee Valley consists of a basal unit of crossbedded coarse sand about 150 feet thick, overlain by about 260 feet of laminated fossiliferous clay which is for the most part sandy, carbonaceous, and highly micaceous. The clay member in fresh exposures contains abundant soft thin fossil shells and, in some beds, some larger and thicker shells. The clay gives way to sand toward the east by a relatively rapid change of facies. East of the Flint River the Blufftown cannot be differentiated from the underlying 
Eutaw formation or from the overlying Cusseta sand, but as the combined thickness of all 3 formations is less than 400 feet in the Flint River valley, it is obvious that all formations are much thinner than in the Chattahoochee River region.

The Cusseta sand in bluffs along the Chattahoochee River consists of glauconitic coarse to fine sand containing abundant fossil shells and grading upward into glauconitic fine sand and chocolate-brown clay. Only a few miles east of the river in upland exposures it consists of irregularly crossbedded coarse to gravelly sand containing white kaolin balls and has few indications of marine origin. Farther east in Taylor County the formation contains lenses of kaolin, some of which are of minable thickness. The Cusseta sand is about 185 feet thick in the Chattahoochee River region. As far east as the Flint River it appears to maintain about this thickness; farther east it cannot be distinguished from the underlying Blufftown formation.

The Ripley formation rests conformably on the Cusseta sand. In western Georgia it consists of calcareous and clayey, in places marly, fine to coarse sand containing abundant fossil shells. Toward the east its facies changes rapidly, but it is recognizable as a marine formation farther east than any other bed of the Cretaceous. Borings of Halymenites.major and rippled bedding suggesting shallow marine conditions continue at least as far east as the Ocmulgee River. Farther east the Ripley cannot be mapped separately from other Cretaceous formations, although a short distance east of the river some beds of sand suggest correlation with the Ripley because they contain borings of Halymenites major and lie below beds of coarser sand (probably the Providence sand). The Ripley formation is about 1.35 feet thick in the Chattahoochee River valley, but it is not more than 50 feet thick just west of the Ocmulgee River.

The Providence sand in bluffs along the Chattahoochee River is glauconitic fossiliferous coarse to fine sand. A few miles east of the river and up the dip in Stewart County it consists of coarse crossbedded sand containing minor beds of white and variegated clay. The formation maintains this lithologic character toward the east, except that locally between the Flint and Ocmulgee Rivers it contains thicker beds of generally sandy kaolin. East of the Ocmulgee River it cannot be certainly recognized, although there is a possibility that the large commercial kaolin bodies of central Georgia are in beds equivalent to the Providence sand. The formation is about $\mathbf{1 6 5}$ feet thick in the drainage area of the Chattahoochee River and about 125 feet thick in southeastern Marion County. From northwestern Macon County eastward the formation is progressively overlapped by Tertiary sediments.

In general, all the Upper Cretaceous formations dip south-southeastward at 20 to 30 feet to the mile. The higher formations have a slightly more northerly strike than the lower formations; as a result they overlap underlying units toward the east. The Tertiary formations strike almost due northeast and in central and eastern Georgia conceal successively older Cretaceous formations. In eastern Georgia Tertiary strata lie on crystalline rocks on stream divides, and the Cretaceous beds are exposed only in the deeper stream valleys.

\section{INTRODUCTION}

\section{PURPOSE OF INVESTIGATION}

In 1944 the U. S. Geological Survey began, as a part of its wartime program of oil and gas investigations, a study of the outcrop relations of Cretaceous formations that had recently begun to produce oil and 
gas down the dip in southern Mississippi. The first mapping and stratigraphic studies on this project were carried on in western Alabama. The program was later extended eastward to obtain information on facies changes in surface Cretaceous rocks that would help explain distribution of different facies in the subsurface of the East Gulf Coastal Plain.

Much has been learned about the Cretaceous in Mississippi and western Alabama since rocks of this age have become productive of oil and gas. Most of these rocks are marine and many of them (the greater part of the Selma group) are chalk of varying degrees of purity. From 1947 to 1949 the writer traced key beds from the chalk facies of central Alabama eastward into a sand and clay facies in eastern Alabama and Georgia. The field work in Georgia was done between May and November in 1949.

The present investigation was requested by the Georgia Department of Mines, Mining, and Geology to gain information that would aid in interpreting subsurface geology in oil and gas investigations and ground-water studies; it would also aid prospecting for high-grade clay deposits in central Georgia and would provide an additional segment of mapping that could be incorporated in a new edition of the geologic map of Georgia.

\section{ACKNOWLEDGMENTS}

F. Stearns MacNeil lent field maps he had made in an earlier survey of Cenozoic formations of Georgia (MacNeil, 1947). These maps saved much time in accurately locating the Cretaceous and Tertiary contact. Louis I. Ray permitted study of his unpublished geologic maps of the Fort Benning Military Reservation. The author also used extensively a U. S. Geological Survey unpublished administrative report on the stratigraphy of the Cretaceous of central Georgia, prepared during 1943 by I. W. Stephenson and R. M. Thompson. S. A. Herrick and H. E. LeGrand, of the Ground Water Branch, U. S. Geological Survey, who have studied ground-water conditions for a number of years in the Georgia coastal plain, cooperated unreservedly in this study. LeGrand provided copies of unpublished geologic maps of central and eastern Georgia which he had prepared to accompany ground-water reports. Herrick furnished subsurface data concerning wells drilled for water and for oil exploration in western and central Georgia and lent well samples for examination. The advice of Herrick and LeGrand was especially helpful in identifying in the field the basal Tertiary formations in central Georgia where there has been considerable drilling of shallow wells in recent years. LaMoreaux's reports (1946a, b) and the strategic-mineral maps by Thompson (1943) and Warren and Thompson (1943) were used to 
compile the map eastward from the Ocmulgee River. (See index map, pl. 1.)

The work in the Chattahoochee Valley region was greatly facilitated by the generous cooperation of the officers of The Infantry School, Fort Benning, Ga. Especially helpful was Mr. H. F. Naehr, civilian engineer of the Post Engineer's office, who furnished maps of the reservation and made many other arrangements to facilitate the survey. The Post Engineer's office also made a boat available for use in studying the formations along the Chattahoochee River as far south as Blufftown.

The author was assisted in the field by Soli Bapuji, Alfredo Rosenzweig, Laurence E. Shirley, and Charles W. Drennen. Mr. Bapuji, a citizen of India, accompanied the party at his own expense as an observer. Mr. Rosenzweig was an in-service trainee assigned to the party through the auspices of the Division of Exchange of Persons, U. S. State Department. In addition to acting as field assistant, Mr. Drennen mapped the contact of the Coastal Plain sediments and the crystalline rocks in west-central Georgia, and Mr. Shirley compiled the west half of the map, county by county, as the field work was finished. Miss Ruth Atherton did much of the library research in connection with the history of geologic nomenclature in Georgia.

The work was directed by Watson H. Monroe, Chief of Eastern Field Investigations of the Fuels Branch, who planned this project and the others on the Cretaceous of the southeastern States that preceded it.

\section{PREVIOUS GEOLOGIC WORK}

The most detailed stratigraphic work previously done on the outcropping Cretaceous rocks of Georgia was that of Stephenson (1911). C. Wythe Cooke mapped in reconnaissance the Coastal Plain for the State geologic map of 1939. Monroe (1941) was the first to trace beds of the Selma group from western and central Alabama into the Chattahoochee River region. Cooke (1943), in describing the geology of the Coastal Plain of Georgia, summarized the stratigraphy from his own and from Stephenson's earlier work and brought the terminology up to date.

Several workers have recently studied the stratigraphy of various parts of the outcrop area of the Cretaceous rocks of Georgia. Warren and Thompson (1943) mapped the beds of several kaolin-producing areas of east-central Georgia, chiefly in Twiggs, Wilkinson, and Washington Counties, as parts of a strategic-minerals investigation. Stephenson and Thompson in 1943 made a reconnaissance of the clayproducing beds and their equivalents in west-central Georgia. Their findings were incorporated in an administrative report which was extensively used in this survey. In 1945 LaMoreaux (1946a, b) 
studied and summarized the Warren and Thompson maps and mapped the Coastal Plain in Twiggs, Wilkinson, Washington, Jones, Baldwin, and Hancock Counties as part of a ground-water study. In 1946 I eGrand extended LaMoreaux's mapping eastward to the Savannah River and then mapped westward from Twiggs County, covering several counties toward the Chattahoochee River. In $1946 \mathrm{MacNeil}$ (1947) mapped the Tertiary of Georgia, and necessarily included the upper limit of Cretaceous rocks. In 1947 Ray mapped Fort Benning and vicinity, in western Georgia, in a study of military geology. In 1947-49 the writer (1950) mapped the Cretaceous beds of eastern Alabama and traced the formations from central Alabama, where much of the section is chalky, through an area of gradually changing facies, to the sands and clays of the Chattahoochee River region.

\section{PRESENT INVESTIGATION}

When the more easily identified Cretaceous units of eastern Alabama were traced into Georgia it was found that several of the contacts previously mapped in Georgia were not the same as those that had been traced eastward through Alabama. The whole Cretaceous area in western Georgia, therefore, from the Chattahoochee to the Ocmulgee Rivers, was mapped to conform with the stratigraphic units mapped in Alabama (pl. 1). The differences between those stratigraphic units of Ray and those traced through eastern Alabama by the writer are shown in the columnar section of rocks exposed in the Chattahoochee River valley. (See pl. 2.)

'The fact that a terminology different from that of some earlier workers has been assigned certain of the beds reflects in part a different philosophy. In earlier work, facies was considered most important, and most formations were named and mapped on that basis. The name "Tuscaloosa formation," for example, was applied to all apparently nonmarine pale-tinted generally coarse-grained sediments that contain lenses of variegated clay. In the current work the cyclic nature of the sediments has been emphasized. Most formations traced from central Alabama, where breaks in the sedimentation are definitely marked, are composed of one or more cycles of deposition. Units of these cycles were traced considerable distances to the east even though the facies had changed from marine to nonmarine.

Most cycles in Cretaceous rocks of the Coastal Plain begin with coarse sand or gravel, progress upward through fine sand and clay and even chalky clay or chalk, and end with the beginning of another deposit of coarse sediment. Many cycles are only partial, the normal deposition having been arrested and a new cycle begun. East of the Chattahoochee Valley much of the sediment is coarse and, except for the Ripley formation which continues with distinct lithologic 
character at least to the Ocmulgee River, most cyclic deposits consist of nondistinctive beds of pale sand and white clay. A few lithologic units and their topographic expressions are continuous, however, and with the aid of structure contours on traceable beds the formations were traced for long distances in an easterly direction.

No attempt was made to map the units east of the Ocmulgee River because of the difficulties of subdividing the Cretaceous. As the beds there seem to be the equivalent of most of the Upper Cretaceous sequence of the Chattahoochee Valley, they were mapped as undifferentiated Cretaceous rocks. Reconnaissance investigations showed the former mapping of the limits of the Cretaceous strata between the Ocmulgee and Savannah Rivers (although these strata were previously termed the Tuscaloosa formation) to be satisfactory, so the maps of LaMoreaux and LeGrand are used in somewhat generalized form. The Cretaceous and Tertiary contact of MacNeil is used with local modifications.

The structure of the Upper Cretaceous formations was determined by contouring several traceable horizons within and bounding the Cretaceous in the area between the Chattahoochee and Ocmulgee Rivers. The structure contours, based on altimeter readings, are shown on plate 3. These contour lines indicate the approximate strike and dip of each horizon traced. The thickness of each formation may be inferred by comparison of the projected top and base of each formation. The contour lines also show the overlapping of some of the higher Cretaceous and overlying Tertiary beds.

Stephenson, Cooke, and others have described many of the local details of the geology of the Cretaceous of Georgia. The present report describes chiefly those localities that have been recently exposed, those that the writer considers the principal key exposures, and those on which he places a different stratigraphic interpretation from that of earlier workers.

The great variations in color of the rocks and their weathered products in the Southeastern States make it extremely difficult to describe the rocks in terms of standard colors such as proposed by the Rock-color Chart Committee (Goddard, chairman, and others, 1948). 'The weathered rocks and the soils of this warm, humid climate are commonly mottled and variegated with red, yellow, purple, and brown hues. The varying intensity of weathering has produced so many shades of color, especially in the impure clays, that one cannot with accuracy and brevity describe them. This depth and degree of weathering varies not only with type of material but also with topographic position. Consequently only generalized descriptive color terms as used in former descriptions of the rocks of this region are used in this report. 
The investigation has shown that the predominantly chalky Selma group of central and western Alabama becomes more sandy and less marine eastward until in central Georgia the entire group apparently consists of a heterogeneous mixture of fine to coarse sand containing lenses of kaolin. The underlying Tuscaloosa and Eutaw formations also grade eastward into similar sand and clay, so that in eastern Georgia it is impracticable and perhaps impossible to separate mappable components of the Upper Cretaceous series. The investigation has shown conclusively, however, that the strata formerly called Tuscaloosa in central and eastern Georgia actually are equivalent to most of the Upper Cretaceous sequence exposed in the Chattahoochee River valley. The Tuscaloosa proper is confined to a thin basal unit impracticable to map separately.

Used as bases for field mapping during this survey were the new topographic maps of 10 quadrangles in the western part of the area, published by the U. S. Geological Survey and the Army Map Service, and the county maps of the Georgia Highway Department for the rest of the area. Altitudes and place names have been used generally to facilitate the reader's location of these points on the new maps.

\section{STRATIGRAPHY}

\section{BASEMENT ROCKS}

Throughout Georgia the basal sedimentary beds of the Coastal Plain lie on crystalline rocks of the Piedmont. These basement crystalline rocks comprise igneous as well as metamorphosed sedimentary and igneous rocks of many types and of various ages from pre-Cambrian to Triassic. They include granite and granite gneiss, diorite and diorite gneiss, diabase, hornblende and mica schist, and quartzite.

Most of the crystalline rocks were deeply weathered when the first sediments of the Tuscaloosa formation were deposited on them. The basal conglomeratic beds of the Tuscaloosa reflect the weathered character of the bedrock in that practically all the gravel consists of angular fragments of resistant vein quartz of local origin. Residual veins of similar material can be traced today, cutting the weathered saprolite beneath the basal Coastal Plain beds and, to the north, in the soils of the Piedmont plateau.

Although locally irregular, the contact between the Coastal Plain and the Piedmont rocks is fairly smooth. During the progressive encroachment of the sea during Cretaceous time, residual materials of the disintegrated older rocks were reworked and the coarser materials were concentrated into the basal beds of the Coastal Plain. Some irregularity may have resulted from the trenching of the deeply 
weathered crystalline rocks by streams during early Tuscaloosa time, but most of the irregularity is due to the original relief on the crystalline surface, though slight, brought about by differential weathering and erosion in pre-Tuscaloosa time.

In western Georgia the strike of the surface of the crystalline rocks, or the contact of these rocks and the overlying basal Coastal Plain beds, averages $\mathrm{N}$. $77^{\circ} \mathrm{E}$. (pl. 3). In Bibb County, halfway across the State, it strikes N. $65^{\circ}$ E., but between Macon and Augusta it strikes on an average of about $\mathrm{N} .55^{\circ} \mathrm{E}$. The dip on the contact in the outcrop area is southeastward, 55 or 60 feet to the mile in the Chattahoochee River region, about 100 feet to the mile in southeastern Talbot and in Taylor and Crawford Counties, and about 70 or 80 feet to the mile in Bibb County. East of this county the dip on the contact is apparently less, but no data were obtained during this survey.

\section{CRETACEOUS}

\section{TUSCALOOSA FORMATION}

GENERAL FEATURES

Name.-The name Tuscaloosa formation was assigned by Smith and Johnson (1887, p. 18, 95-117) to the basal Coastal Plain strata exposed in Alabama. The formation was named for the city, the county, and the river of Tuscaloosa - the river is now known only by the English translation, Black Warrior or Warrior River. J. W. W. Spencer (1890) extended the usage of the name into Georgia to designate the outcropping basal Cretaceous strata. Stephenson (1911), on the basis of identification of fossil plants by Edward W. Berry, called these rocks in eastern Alabama and their equivalents in Georgia Lower Cretaceous. Later, Berry (1923) reassigned the fossil plants to the Tuscaloosa of Upper Cretaceous age. In 1926 Cooke correlated the beds east of Flint River that had been assigned to the Lower Cretaceous with the Upper Cretaceous Middendorf formation of South Carolina. Cooke then proposed to call these deposits Tuscaloosa in eastern Alabama and western Georgia and Middendorf in eastern Georgia and South Carolina. At that time Cooke thought the Tuscaloosa and Middendorf might not be equivalent, but by 1936 he had decided they were equivalent, and he then extended the use of the name Tuscaloosa into South Carolina.

Areal extent.-The Tuscaloosa formation crops out in a gradually narrowing east-northeastward-trending belt from the Chattahoochee River near Columbus to the Ocmulgee River near Macon. A thin remnant of the Tuscaloosa can be recognized at the base of the Cretaceous east of the Ocmulgee River, but it is so thin and so difficult to separate from the overlying rocks that in this report it is not differen- 
tiated from the rest of Cretaceous rocks. A thin indistinguishable remnant of Tuscaloosa may be present at the base of the Cretaceous in deep valleys in the eastern part of the State.

The belt of outcrop of the Tuscaloosa formation is about 11 miles wide in the Chattahoochee River valley, about 6 miles wide in the Flint River valley, and about 5 miles wide at the Ocmulgee River. As the base of the Tuscaloosa has a steeper dip than the top in updip areas, the formation is wedge shaped and has a wider outcrop belt in downdip areas than in updip areas. In the updip area the belt of outcrop ranges from a maximum of about 8 miles in Muscogee County to a minimum of less than a mile in Crawford and Bibb Counties.

Lithologic character.-The Tuscaloosa formation consists generally of coarse to gravelly and arkosic sand, and of subordinate beds of mottled clay and silt. Its materials, derived from disintegrated crystalline rocks of the Piedmont Plateau to the north, were apparently only partially decayed before their removal and deposition in the Coastal Plain. In their present position the sandy sediments contain abundant grains of partially altered feldspar and mica grains, and the gravel consists mostly of quartz pebbles. Pyrite nodules are common, and sandy nodules cemented by crystalline barite are less common. Upon weathering, the sand becomes pale shades of gray to yellow, stained by the relatively high iron oxide content. Concretionary ironstone is found commonly as nodules or as layers ramifying the sand. The layers are highly irregular and locally are tubular.

The silts and clays are of deeper colors, generally mottled. Unweathered, they are generally drab shades of olive or greenish gray mottled with red, reddish brown, and purple, with all gradations of coloring between. Weathering tends to deepen the shades of mottling or staining by oxidation of the iron. Siderite spherules about 1 millimeter in diameter are abundant in the silts and clays in some localities and weather to red or brown spots of iron oxide. The clays contain also varying proportions of organic material such as lignitic logs and stems, as well as leaf fragments and other materials which are identifiable with difficulty. At some places the clays of the Tuscaloosa are pisolitic and bauxitic. Generally the pisolites are ferruginous, but white pisolitic clay was found near the top of the Tuscaloosa formation in Crawford County 1 mile southwest of the Middle Georgia Pottery, about 10 miles east-northeast of Roberta.

In eastern Alabama and Georgia the clays and sands of the Tuscaloosa formation are locally semi-indurated and appear as rock masses resistant to erosion where exposed in road cuts, on steeper hill slopes, or in stream bottoms. In many streams the rock forms shoals and waterfalls, but because the induration is not complete, the rock is 
generally highly pitted or cavernous. A little weathering and dehydration seem to make the rock harder, the clays becoming claystones and the sandstones forming hard rock ledges. The cement in this rock is apparently both siliceous and argillaceous. By contrast, induration was not as noted in the Tuscaloosa of western Alabama except where the cementing material was calcareous or ferruginous.

In addition to differing in induration, beds of the Tuscaloosa formation in eastern Alabama and Georgia are arkosic. In western Alabama, where the source of the Tuscaloosa sediments was the Paleozoic sedimentary rocks of the Interior Low Plateaus, the beds contain cherty sands, or glauconite where marine. The gravel in the formation in eastern Alabama and Georgia consists chiefly of quartz pebbles instead of chert as in western Alabama, and the clay of the eastern deposits is generally more deeply mottled than that in western Alabama.

Stratigraphy.-The basal beds of the Tuscaloosa formation of western Georgia consist of coarse arkosic indurated sand having generally angular quartz pebbles scattered throughout or concentrated in lenses. These beds grade upward into, and are interbedded with, semi-indurated sandstone and mottled red, brown, and green clay and silt. This basal lithologic unit of variable character ranges from 30 to 50 feet in thickness.

The beds of variegated silt and clay in this basal unit in the Chattahoochee River valley contain abundant tubular boringlike structures. Unlike the nodular Halymenites borings, these questionable borings have smooth walls. They are crooked and branching and typically end in a hemisphere. They range in diameter from half an inch or less to an inch and ramify through the clay in a vermiculate pattern. In most exposures they are filled with reddish-brown clay, in contrast to the greenish-gray or only slightly reddish-brown-mottled clay mass in which they are found. Weathering tends to make the whole mass reddish brown, mottled with various shades, but the borings are generally more ferruginous than their matrix. Similar questionable borings have been observed near the base of the Tuscaloosa formation in numerous localities from northern Macon County, Ala., to eastern Talbot County, Ga.

Mottled clays and enclosing sands at Decatur Bluff in the northwestern part of Macon County, Ala., are similar to these basal sediments of the Tuscaloosa formation in Georgia and occupy a corresponding stratigraphic position. There, a high bank of the Tallapoosa River exposing about 100 feet of strata was described by Langdon in Smith, Johnson, and Langdon (1894, p. 342, 435, 436). In these beds Stephenson (1911, p. 342) found a mold of a shell of Unio sp. associated with poorly preserved leaf remains. These beds co- 
relate, in turn, with the marine Eoline formation near the base of the Tuscaloosa group of western Alabama, as mapped by Monroe, Conant, and Eargle (1946). If these correlations are correct, then the clays with borings near the base of the Coastal Plain beds in Georgia are the eastern shallow-water, or nonmarine, equivalents of the Eoline formation of western Alabama.

Overlying the mottled silts and clays of the basal Tuscaloosa of western Georgia is an upper unit of relatively uniform masses of gravelly sand that contains a few beds of gray clay, commonly variegated with intense purple or purplish-red clay. The contact between the basal and upper units of the Tuscaloosa seems to be irregular and may represent a depositional break, but east of Talbot County no distinctive or traceable contacts can be recognized in the narrowing outcrop of the Tuscaloosa.

Thickness.-The Tuscaloosa formation averages a little more than 250 feet in thickness in the Chattahoochee River valley. In Phenix City and Girard, Ala., just across the river from Columbus, Ga., the Tuscaloosa is about 265 feet thick.

To the east, however, several factors affect its thickness. The dip on the base is notably more steep than on its top; therefore, it increases in thickness in a downdip direction. In Talbot and Taylor Counties, for example, where the dip on the base is about 80 to 100 feet per mile, the dip on the top is only about 40 feet. Another factor is the slight overlap of the Tuscaloosa by the Eutaw formation to the east. In the vicinity of Macon only about 25 feet of the Tuscaloosa is exposed on the higher hills. In the eastern part of the State Tertiary formations overlap all the Cretaceous; the equivalent of the Tuscaloosa, if exposed at all, would be found far down the dip in the lower parts of the deeper creek valleys.

\section{IOCAI DETAILS}

Muscogee County.-Wide terraces of the Chattahoochee River cover most of the outcrop area of the Tuscaloosa formation in and south of the city of Columbus, but several local streams and large creeks that cut through the Quaternary sediments afford excellent exposures of the basal Tuscaloosa beds and show the contact with the underlying crystalline rocks. North and east of Columbus, however, up the dip and on higher land where terrace materials are patchy, excellent exposures of the basal Tuscaloosa are found. In addition, recently rejuvenated secondary streams furnish good exposures of fresh strata in stream beds.

One of the best of the fresh exposures of the contact between the Tuscaloosa formation and the crystalline rock was found in the bed of Cooper Creek about 3 miles east of Columbus and 1,000 feet upstream from the U. S. Highway 180 bridge beside Parkhill Cemetery. 
Section in bed of Cooper Creek beside Parkhill Cemetery, 3 miles east of Columbus

Tuscaloosa formation:

Clay, blue-gray, sticky, soft, carbonaceous

Sand, clayey, buff and gray, mottled; upper surface lignitic. Grades into bed below

Sand, clayey, ferruginous; contains small pebbly ferruginous concretions. Sharply overlies bed below

Unconformity.

Residuum (highly weathered saprolite) :

Clay and coarse sand, light-yellow and lavender, mottled, tough, resistant; forms shoals in bed of stream for 500 feet

About 500 feet upstream soft saprolite of the crystalline rock is found in the banks of the stream. About half a mile north of this outcrop, on the valley side east of Cooper Creek, arkosic sand of the Tuscaloosa lies abruptly on variegated sandy clay (granite residuum) containing lavender ferruginous nodules near the top. The highly weathered residuum grades downward into saprolite about 15 feet below the contact with the Tuscaloosa. The contact here is about 310 feet above sea level; in the bed of the creek at Parkhill Cemetery, nearly a mile down the dip, it is about 270 feet.

Reddish-brown clay that grades downward into gray micaceous silty clay, with borings, forms the stream bed in a city park that faces Columbus High School, about 2 miles northeast of the Columbus City Hall. A quarter of a mile north, near St. Elmo School, the bed of the stream is variegated kaolinitic sandy clay, and half a mile farther north the bottom of the valley is soft saprolite of granite gneiss and pegmatite. These exposures show that an inlier of crystalline rocks is surrounded by basal beds of the Tuscaloosa formation. Borings in the clay in front of the high school are smooth and terminate in nodulelike hemispheres.

Stephenson $(1911$, p. 78) reports the contact between the Tuscaloosa formation and the crystalline rock to be in the bed of the Chattahoochee River about 5 feet above low water at the west end of the Central of Georgia Railway Co. bridge about half a mile west of the city hall and courthouse. This is the lowest known outcrop of that contact in this region and is about 185 feet above sea level.

Some of the better exposures of the contact between the Tuscaloosa and the crystalline rock are on the Midland and Upatoi quadrangles in cuts along U. S. Highway 80, 10 miles or more east of Columbus. In this area the highway traverses a number of hills capped with sandstone of the Tuscaloosa and valleys cut into the crystalline rocks. In most places, beneath the Tuscaloosa sediments, a residuum of extremely weathered mottled saprolite, as much as 10 feet thick and generally purple and reddish brown, grades downward into saprolite of granite gneiss. In some places this residuum has been reworked 
by pre-Tuscaloosa colluvial processes, or it is the thin remnant of a previous sedimentary deposit or of a soil.

Generally, however, the zone of intensely weathered material grades downward within 5 feet into recognizable saprolite that has discernible rock structure. Such an exposure is found in cuts on U. S. Highway 80 a quarter of a mile east of the crossing of the highway by Schatulga Road (southwest part of Midland quadrangle). Here, gravelly sand of the Tuscaloosa lies directly on purple clay that grades downward into saprolite. A better exposure is $1 \frac{1}{2}$ miles farther east on U. S. Highway 80, 300 yards west of the point where Tenth Armored Division Road (on the south) and Lynch Road (on the north) cross the highway.

\section{Section on U. S. Highway 80, 900 yards west of intersection with Tenth Armored Division Road to south and Lynch Road to north}

Tuscaloosa formation :

Feet

Conglomerate, fine quartz and clay-ball gravel and arkosic sand. From top of cut

Clay, silty, light-greenish-gray; conspicuous reddish-brown borings.

Irregular base. About.

Sand, mottled soft, kaolinitic, chloritic. To bottom of cut

4

In the road ditch, highly irregular sandy crystalline barite concretions as much as 6 inches long are found in the lower bed of sand. Crystalline rock is found about 20 feet lower farther to the west.

Fresh exposures of typical Tuscaloosa sediments higher than the contact with the crystalline rock may be seen at numerous places in Columbus and in Phenix and Girard on the Alabama side of the Chattahoochee River.

In the bed of Bull Creek southeast of Columbus are several significant exposures of the Tuscaloosa formation. One is in this creek, behind a grammar school, and extends from beneath the bridge of State Highway 103 (Buena Vista Road) to the mouth of the nearby tributary, Lindsey Creek. There the rock is indurated coarse sand and silt, irregularly interbedded with drab purple and reddish-brown mottled clay containing abundant small buff siderite spherules about 1 millimeter or less in diameter. Across the road from the school in an excavated bank 40 feet above the bed of the creek is the contact between this indurated material, chiefly mottled clay, and overlying gravelly arkosic coarse sand. The altitude of this contact is about 265 feet. A similar contact, perhaps the same horizon, is found half a mile downstream to the southwest in the bank of the creek beside a lumber yard, at an altitude of 213 feet. Here, 3 feet of arkosic coarse sand sharply overlies 4 feet of brittle variegated purplish-red and bluish-gray sandy clay.

Drab purplish-red and greenish-gray mottled silt and clay overlying gray micaceous sand is exposed immediately downstream from the

$339546-55-2$ 
bridge of U. S. Highway 27 (Columbus-Fort Benning road) over Bull Creek. About 200 yards to the southwest, Stephenson (1911, p. 81) reports the top of the crystalline rocks to be 15 feet above sea level in a well 245 feet deep.

Weathered sediments of the upper part of the Tuscaloosa are exposed in many of the roadcuts southeast and east of Bull Creek where these roads ascend the rolling hills from Columbus toward Fort Benning Military Reservation. Along the Buena Vista road (State Highway 103) and secondary roads to the north are exposures of arkosic pale-red sand and thinner beds of mottled clay. High hills beginning about 5 miles east of Columbus are capped by outliers of the Eutaw formation. Here the contact of these beds with purplishred clays and very-pale-red-weathering sands of the Tuscaloosa can be seen. The same horizon can be studied in good exposures on Steam Mill Road, St. Marys Road, and on Columbus Avenue, and in cuts along the Central of Georgia Railway and the Seaboard Air Line Railroad, 5 miles southeast of Columbus (fig. 1). In the last-mentioned place 12 feet of red crossbedded coarse sand of the Eutaw formation overlies 12 to 15 feet of pale-red clayey coarse sand of the Tuscaloosa, which, in turn, overlies 2 to 3 feet of variegated sandy clay grading downward into sand.

On Schatulga Road, south of Bull Creek (southwest corner of the Midland quadrangle and northwest corner of the Ochillee quadrangle) a nearly complete section of the Tuscaloosa is partially exposed for more than a mile from Bull Creek south to the crest of the hill.

\section{Section on Schatulga Road south of Bull Creek}

Eutaw formation:

Sand, red, crossbedded; contains borings of Halymenites major. Altitude of base about 500 feet. About_.

Tuscaloosa formation :

Sand, gravelly ; poorly exposed in hills on which the Muscogee County Poor Farm is located. Altitude of base about 425 feet. About_-.-

Sand, clayey, and purple-mottled gray clay; poorly exposed. Altitude of base about 370 feet. About

Covered. About

Sand, coarse, gravelly, arkosic, crossbedded; pebbles as much as 1 inch in diameter; upper 3 feet clayey, light gray, light tan weathering; firm but friable. From top of cut

Clay, silty, reddish-brown and greenish-gray ; contains smooth-walled borings. Grades abruptly into bed below.

Sand, arkosic, indurated, crossbedded; forms hard sandstone ledges 6 to 10 feet below top of stratum; especially hard near slope surface_

Clay, silty, reddish-brown and gray; contains borings. Grades into bed below

Sand, clayey, brown, mpttled with gray ; grades downward into coarse loose to slightly indurated arkosic sand. Extends to bottom of valley, whose approximate altitude here is 300 feet 
Chattahoochee County.-The Tuscaloosa formation occupies the bottom of Upatoi Creek for its entire length along the boundary of Chattahoochee and Muscogee Counties. In the Chattahoochee River and in the nearby lower part of Upatoi Creek, the contact between the Eutaw and the Tuscaloosa is low in the valley wall. At Broken
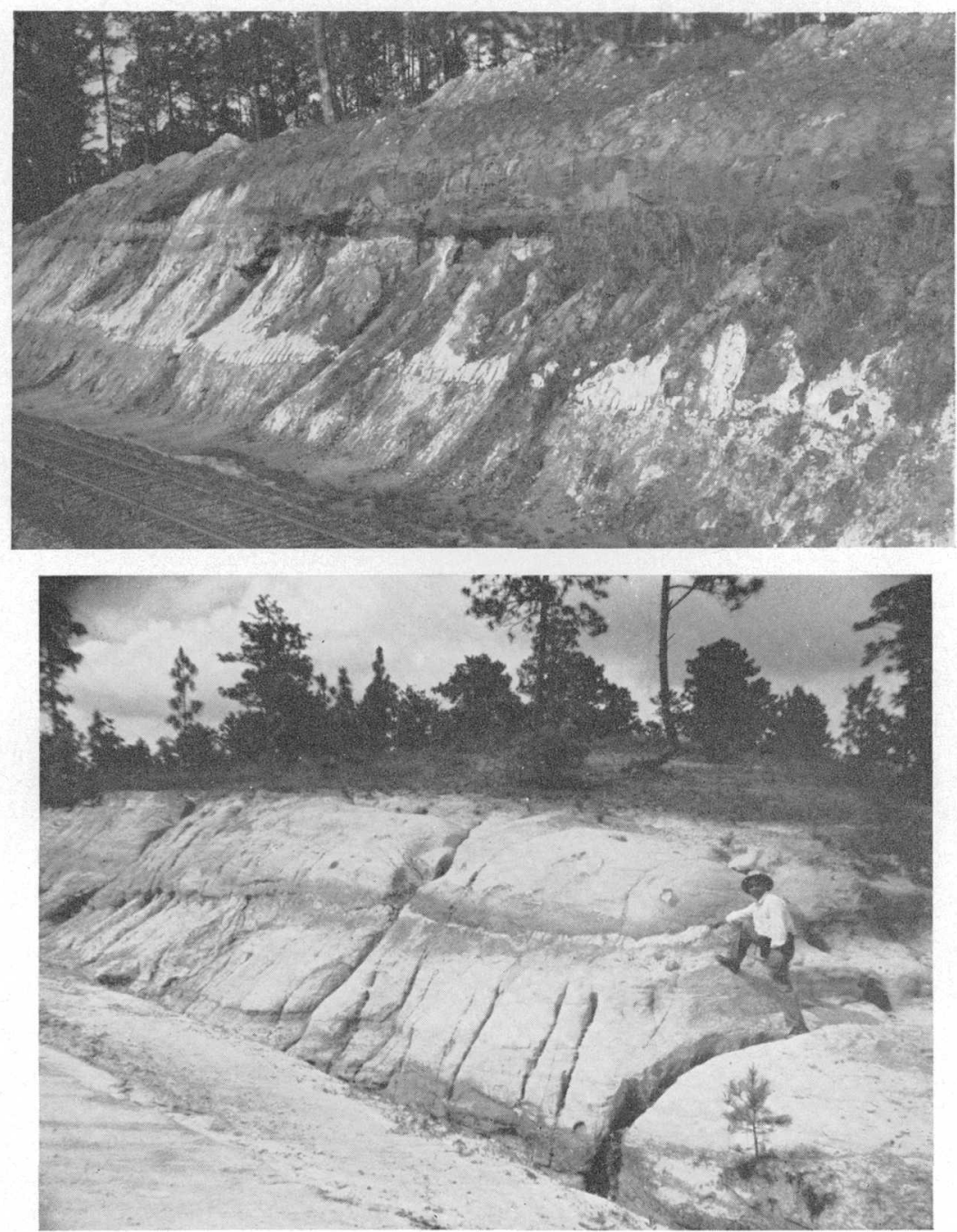

Figure 1.-Upper. Downdip exposure of the contact of the Tuscaloosa and Eutaw formations. The basal sand of the marine Eutaw formation at the top of the cut weathers dark red. The upper bed of the Tuscaloosa formation, nearly white sandy clay about 4 feet thick, overlies pale-gray coarse sand. Railroad cut 5 miles southeast of the Muscogee County courthouse, Columbus. Lower. Updip exposure of the contact of the Tuscaloosa and Eutaw formations. The basal bed of the Eutaw, here a pale coarse sand, locally contains Halymenites borings. The Tuscaloosa consists of pale-gray loose sand having a thin bed of white clay at the top. The man is pointing to the contact with the overlying Eutaw. On Steam Mill Road $5^{1 / 2}$ miles east of Columbus. 
Arrow Bend the contact, about 180 feet above sea level, is at water level during medium stages of the river. Stephenson (1911, p. 118119) has described this section, and Cooke (1943, p. 16) has repeated the fossil lists. Stephenson has described also the section at McBrides Bridge on Upatoi Creek (on the road called Red Arrow Road on military maps), and Berry (1919) has described a collection of fossil plants from here.

The contact between the Eutaw and the Tuscaloosa is well exposed in cuts on U. S. Highway 27, just south of Upatoi Creek. On Hourglass and Underwood Roads, on the uplands southeast of Upatoi Creek, about 11 miles east of Columbus, are other good exposures of this contact. Hard sandstone near the top of the Tuscaloosa forms shoals in Bonham Creek at the bridge on Hourglass Road. Another excellent section of the contact between the Eutaw and the Tuscaloosa is on Underwood Road, a quarter of a mile south of Cooks Mill Pond, three-fourths of a mile south of the bridge of State Highway 103 over Upatoi Creek. .

\section{Section a quarter of a mile south of Coolss Mill Pond (Ochillee quadrangle)}

Eutaw formation:

Feet

Clay, ferruginous; white concretionary crusts at base. Caps hill_--

Sand, very coarse, and fine gravel, crossbedded; abundant borings of

Halymenites major 5 feet below top; contains silicified wood and feldspar grains. About.

Sand, coarse, crossbedded; upper 2 feet clayey and lavender; contains fine gravel, mostly quartz but some feldspar, and small borings, probably Halymenites sp. Altitude of base, 325 feet.-_-_-_-

Unconformity.

Tuscaloosa formation:

Clay, gray, mottled with maroon, massive

Sand, coarse, slightly clayey, pale-reddish-purple, mottled. Exposed to bottom of hill. About.

Talbot County.-In the southern part of Talbot County, the Tuscaloosa formation consists of outliers in a belt 2 to 4 miles wide. The weathered sands of the Eutaw formation are much lighter in color in this area than in Muscogee County and are therefore less easily distinguished from the Tuscaloosa. The basal beds of the Tuscaloosa here contain little gravel, since much of the sediment apparently was deposited in estuaries or on flat, wide alluvial plains that encroached on land surfaced with a deeply weathered saprolite of crystalline rocks. Most of the materials of pebble size at the base of the formation consist of broken and angular fragments of quartz-vein rock concentrated by weak currents. This is in strong contrast to highterrace remnants 650 to 680 feet above sea level, 2 to 4 miles south of Talbotton along U. S. Highway 80, where 20 to 30 feet of mottled coarse and subangular to subrounded gravel and cobbles caps a long 
ridge. This coarse terrace material consists of quartzite boulders that can be traced to Pine Mountain and other hills more than 12 miles to the north and represents material deposited by a comparatively large, swift stream flowing south from that region, perhaps during late Tertiary or early Quaternary time. This outlier, a little more than a square mile in area, almost covers an outlier of basal Tuscaloosa. Several other terrace deposits are west of the Flint River at a comparable height.

A few exposures of basal Tuscaloosa show gravel and cobbles. Such an exposure which shows clearly the contact of the Tuscaloosa formation and the underlying crystalline rocks is the following:

Section on U. S. Highway 80, 0.9 mile north of Geneva

Feet

Soil, sand

Tuscaloosa formation:

Sand, coarse, and fine gravel, tan-weathering, regularly bedded

Clay, sandy, locally gravelly, purplish-red and gray, mottled ; contains pisolites, some are white throughout and others have white shells and are ferruginous with moderate-reddish-brown and yellowishorange streaks inside; intensely weathered. Grades into bed below_

Sand and gravel; locally an indurated basal conglomerate with vein quartz and quartzite gravel and cobbles as much as 6 inches long. Altitude of base (by altimeter) 502 feet. About

Unconformity.

Crystalline rocks (saprolite of dioritic rocks).

South of Geneva on State Highway 41 toward Buena Vista are several exposures of pale crossbedded gravelly sand that sharply overlies light-gray, in part purple-mottled, clay and sand. All are in the Tuscaloosa formation. This contact gradually rises to the north toward Geneva from the valley of Juniper Creek, which is the south boundary of Talbot County. Similar exposures are found along the county road from Geneva to Buena Vista, one of which is the following:

Section on Marion-I'albot County line, south of bridge over Black Creet on the county road from Geneva to Buena Vista

Eutaw formation: $\quad$ Feet

Sand, coarse; overlies white and yellow clayey sand. About_-_-_-- 25

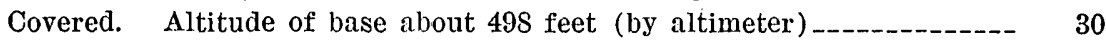

Tuscaloosa formation:

Clay, sandy, poorly exposed; forms seep zone on slope

Sandstone, granular, dark-yellowish-orange, somewhat mottled with reddish brown

Claystone, very-light-gray, mottled with pale reddish brown to moderate reddish brown, semi-indurated; contains coarse sand in places. Exposed to dale bottom. About

Twenty-eight feet downhill from the above section a 3-foot bed of clay, weathering deep reddish brown, rests on granular and pebbly 
sandstone, which is very light gray mottled in places with reddish to dark yellowish orange. This grades downward into a clayey coarse semi-indurated sandstone.

On this same road and in cuts on the old highway along the southeast edge of the village of Geneva is the following section:

Section on northwest-facing hill on old road half a mile southeast of Geneva

Eutaw formation:

Feet

Sand and fine gravel, light-reddish-brown and gray, mottled. Lies irregularly and sharply on bed below. Altitude of base (by altimeter) 648 feet. Exposed, more than

Unconformity.

Tuscaloosa formation:

Clay, silty, very-pale-gray (almost white) to gray, mottled with pink; contains sand lenses; fissile where weathered (not parallel to bedling)

Covered. About_.

Sand, gravelly, very-pale-yellowish- to reddish-brown, crossbedded. About

Clay and sand, more intensely mottled than clay at top of formation. About

In cuts on State Highway 96, immediately north of this locality and beginning about 20 feet below the base of the section described above, are good exposures of lower Tuscaloosa strata.

Section in cuts on State Highuay 96 east of Geneva, 0.3 mile east of junction with U. S. Highway 80

Tuscaloosa formation :

Sand and fine gravel, pale-gray, crossbedded ; covered with loose sandy soil. More than 10

Clay, sandy, pale-yellowish-brown. Sharp basal contact____-__- 6

Sand, gravelly, pale-gray, mottled with yellowish brown at top and purplish and reddish brown (moderate to dark) below. About_----

The easternmost observed exposure of the clay, with borings, near the base of the Tuscaloosa is $31 / 2$ miles northeast of Junction City in a road cut at the west edge of an outlier of that formation, in a region of deeply weathered mica schist containing many quartz veins. The outcrop is a mile east of the Baldwinville crossroads. The following section was logged by C. W. Drennen:

\section{Section 1 mile east of the crossroads at Baldwinville, $31 / 2$ miles northeast of Junction City}

Tuscaloosa formation:

Feet

Sand, coarse, crossbedded; contains small clay balls or pebbles; one

feldspar pebble 2 inches long

Clay, silty, lenticular; many smooth borings. Grades into bed below -- $\quad 10$

Conglomerate, clayey, sandy, ferruginous.___._- 1-3

Unconformity.

Crystalline rocks (saprolite of mica schist). 
Marion County.-The longest and most continuous exposures of the formations from the lower part of the Blufftown well down into the Tuscaloosa formation were made by cuts along the recently improved State Highway 41 (Geneva-Buena Vista) immediately south of the Talbot-Marion County line, on the steep north-facing slope leading down to Juniper Creek. The following section exposes the contact between the Eutaw and the Tuscaloosa:

Section on State Highway 4,1, beginning about half a mile south of Juniper Crcck

Lutaw formation:

Feet

Sand, coarse to medium, pale-yellowish-brown; contains a few thin white kaolin lenses and questionable Halymenites borings; basal 2 feet a very hard, very coarse, pale-yellow, slightly purplishblotched arkosic sand and gravel. Irregular contact at base, with average altitude of 462 feet (by altimeter). About_--------_----

Tuscaloosa formation:

Clay and clayey sand, gray mottled with drab red and purplish red, indurated; grades downward into softer clay that forms a landslide area. About

Covered. About

Sand, coarse, and clay-ball conglomerate, drab, gravelly at base. Base at approximate altitude of 404 feet. Exposed in first cut south of Juniper Creek

Clay, gray, lenticular; grades downward into gravelly sand. Exposed to about 10 feet above bottom of Juniper Creek

Taylor County. - The Tuscaloosa formation crops out in a narrow belt along the north edge of Taylor County and occupies the valley bottoms of Patsiliga Creek and of its tributary, Timms Creek, for most of their: lengths. The formation is less than 80 feet thick along this outcrop area, but, with a southerly dip of about 50 feet to the mile on its top and nearly 100 feet to the mile on its base, its thickness increases notably toward the south. In the northeast corner of the county the formation is found in creek valleys but is partially covered with extensive terraces of the Flint River.

One of the better outcrops of the upper part of the Tuscaloosa extends about 1,000 feet west of U. S. Highway 19 on a hill on an eastwest county road about a mile south of Little Patsiliga Creek and about 8 miles north of Butler. Here, 25 feet of purple-mottled palered silty and sandy clay of the Tuscaloosa formation is overlain abruptly by 11 feet of crossbedded coarse sand having a somewhat redder color and traces of questionable Halymenites borings. The 11-foot bed is presumed to be of the Eutaw formation. It is, in turn, overlain by 7 feet of gravelly red sand of a high terrace of late Tertiary or early Quaternary age.

On U. S. Highway 19 about a quarter of a mile south of Timms Creek, on a steep north slope, is the following section: 
Section in cuts on U. S. Highuay 19, a quarter of a mile south of Timms Creek

Feet

Soil and colluvial sand, brown to gray

Eutaw formation (?) :

Sand, fine to coarse, slightly clayey, light-brownish-red, massive.

Maximum thickness exposed

Sand, generally fine, light-reddish-brown; contains a few coarse grains and fine gravel ; grades downward into the same material, but mottled with yellowish brown

Unconformity.

Tuscaloosa formation:

Clay, kaolinitic, pale-gray, mottled with light reddish brown

Sand, fine, to fine gravel, light-reddish-brown, crossbedded; contains pale-gray clay lenses as much as 1 foot thick, with some of the clay and sand lenses interbedded in thin beds 2 to 4 inches thick. Exposed

Several good exposures of pale sandy clay and gravelly sand of the Tuscaloosa are found in the western part of the county in the valley of Patsiliga Creek and its tributaries, down the dip from higher outliers and projections of the Tuscaloosa formation on hills to the north. Some of these beds are overlain abruptly by red gravelly sand of the Eutaw formation. In the eastern part of the county pale-gray to white purple-mottled clay and purplish-yellow sand of the Tuscaloosa are overlain with pale-reddish-brown ferruginous coarse sand of the Eutaw on the lower slopes of many of the stream valleys. Along the Flint River most of the outcrop area is covered with extensive terraces.

Crawford County.-The highway from Macon to Reynolds through Roberta and Knoxville crosses the contact between the Tuscaloosa formation and the crystalline rock no fewer than 20 times, chiefly along the ragged north edge of the Coastal Plain where basal beds of the Tuscaloosa formation cap hills or project northward on interstream divides. Cuts on this highway expose several complete sections of the thin updip Tuscaloosa.

A series of cuts on State Highway 42, a mile east of Knoxville, has excellent exposures of the Tuscaloosa formation in contact with beds of the Eutaw formation (?) above and crystalline rocks below.

Section east of Culpepper Creek, 1 mile east of Knoxville on State Highway 42

Eutaw formation (?) :

Feet

Sand, coarse, and fine gravel, very-pale-red, crossbedded; contains rounded pebbles as much as $1 \mathrm{inch}$ in diameter. Base at approximate altitude of 545 feet

$10+$

Unconformity (?).

'Tuscaloosa formation:

Clay, drab-gray, mottled with tan. Grades into bed below

Sand, very coarse, and fine gravel, very-pale-gray. Irregular base_- 8-9

Clay, very-light-gray, mottled with purplish red; contains ferruginous nodules 
In the next cut downhill, a few hundred feet west, is very coarse arkosic crossbedded sand with very few scattered angular to subrounded pebbles, generally less than 1 inch long, lying abruptly and irregularly on weathered schist at an altitude of 506 feet (by altimeter).

On a north-facing hillside on a county road $2 \frac{1}{2}$ to 3 miles north of Knoxville is a section that extends from probable Tertiary rocks down into weathered crystalline saprolite. Northeast of there Tertiary strata overlap most of the Cretaceous up the dip on high upland interstream areas.

Section, along a county road. 2112 to 3 miles north of Kinoxville, on a north-facing hillsirle

Tertiary rocks (?) :

Feet

Sand, coarse, clayey, deep-reddish-brown, massive, somewhat ferruginous; contains scatiered subrounded pebbles as much as 1. inch long. Base at approximate altitude of 710 feet. From top of hill_Unconformity (?).

Eutaw formation (?):

Sand, very coarse, very-pale-red; contains lenses of fine gravel composed of subrounded quartz and feldspar pebbles; generally finer below a break 22 feet from the top. Lower $1 \frac{11}{2}$ feet has stringers of subrounded quartz pebbles as much as 1 inch long

Unconformity (?).

Tuscaloosa formation:

Clay, pale-gray, mottled with tan and slightly purplish red._._...--

Gravel, bedded ; grades downward into gravelly sand 10 feet below top and this grades downward into clayey sand that weathers very pale red. Base is not exposed, but saprolite of crystalline rock is exposed in valley to north. About

In the eastern part of the county in the valleys of Echeconnee Creek and its western tributaries, Deep and Whitewater Creeks, are several significant exposures. Given below is one near the Middle Georgia Pottery.

Section in cuts on conty road 1 mile southeast of Middle Georgia Pottery, $1 \%$ miles south of Marshalls Mill on Echeconnee Creek and about 10 miles custnortheast of Roberta

Soil, sandy

Eutaw formation (?):

Sand and fine gravel, light-reddish-brown to pale-purplish-red, mottled with yellow, crossbedded; more gravelly and firm near base below a clay lens as much as $2 \frac{1}{2}$ feet thick

Sand, clayey, and coarse sand, dark-purplish-red and light-gray, mottled; weathers pale yellowish brown; grades downward into faintly crossbedded fine-gravel to granular-sand lenses; some kaolin (weath-

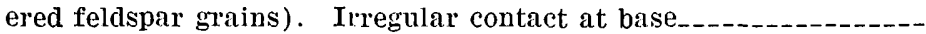

Unconformity (?).

'luscaloosa formation:

Clay, pale-purple to dark-red and white, mottled ferruginous, pisolitic; grades downward into clayey fine to coarse sand at 6 to 8 feet below top 
In the eastern corner of the county in the vicinity of Jacksons Mill on Whitewater Creek, and in cuts on a county road just west of Echeconnee Creek, are good downdip exposures of the top of the Tuscaloosa formation and the beds that overlie it. In a bluff south of the mill and on a road up the steep hill, indurated very coarse clayey sand of the Eutaw formation (?), containing clay balls and nodules of pyrite, as much as 2 inches in diameter, lies on drab-gray, in part purple- and lavender-mottled, sandy clay and clayey sand of the Tuscaloosa formation.

Bibb County.-Exposures of the Tuscaloosa formation similar to those in Crawford County are found in Bibb County along U. S. Highway 80 and secondary roads and in Macon along city streets and railway cuts. In this region the contact between the Eutaw (?) and the Tuscaloosa frequently marks an abrupt change in slope, steeper on the gravelly sand of the Eutaw than on the clays of the Tuscaloosa. Upland slopes on the basal Tuscaloosa differ little from those on the weathered crystalline rocks: the Tuscaloosa, which is only slightly more resistant to weathering than the saprolite of the crystalline rocks, has slightly steeper slopes. Usually, however, valleys in less weathered crystalline rocks have steeper walls and are deeper, and the drainage network is more dense than in the permeable Coastal Plain strata.

Most of the higher hills in Macon, where the bedrock is well exposed, are of the Eutaw formation ( $?)$, but in several places there are exposures of Tuscaloosa. In the Central of Georgia Railway cuts near Stanislaus Circle, just north of the Pionono Avenue viaduct, in northwest Macon, mottled light-red gravelly sand of the Eutaw (?) lies on very pale clayey sand of the Tuscaloosa. In cuts on Neal Avenue in northern Macon near a radio tower, gray sand mottled with purplish red overlies pale-red gravelly sand, both of the Tuscaloosa formation.

On Hill Street just west of Jones Street, west of Rose Hill Cemetery, is a good exposure of clayey sand, mottled with shades of pale red, of the Eutaw (?) and its contact with the Tuscaloosa. In southwestern Macon on Pionono Road light-red gravelly sand of the Eutaw formation (?) lies on pale-red to mottled clayey sand of the Tuscaloosa. On Rocky Creek Road just east of Pionono Road, more than 20 feet of pale clayey sand of the Eutaw (?) lies on about 3 feet of white clay of the Tuscaloosa about 17 feet above the flood plain of Rocky Creek.

Across the Ocmulgee River on Clinton Street, on the highway to Gray, a thin but well-exposed section of Tuscaloosa strata is found in highway cuts. Here, on the hill just south of Georgia Baptist Col- 
lege, is a capping of gravelly sand of the Eutaw formation (?), but farther downhill is about 25 feet of sand and clay of the Tuscaloosa lying on crystalline schists.

\section{EUTAW FORMATION}

\section{GENERAL FEATURES}

Name.-The Eutaw formation was named by Hilgard (1860, p. 62) for the town of Eutaw in western Alabama, the county seat of Greene County. He called the Eutaw a group and included in it rocks between the Paleozoic basement rocks and his Tombigbee sand group. Smith and Johnson (1887, p. 86-95) redefined the formation to include only the beds above the Tuscaloosa formation and below the - Selma chalk. 'They included Hilgard's Tombigbee sand in the Eutaw. Langdon (1891) extended the usage of the name into Georgia but did not include the Tombigbee sand in his Eutaw formation. Stephenson (1911, p. 112) accepted Langdon's definition of the Eutaw but added to it about 120 feet of the overlying sand which Langdon had included in his Ripley formation. Stephenson and Monroe (1938, p. 1642, 1644) redefined the Eutaw formation of eastern Alabama by reviving the name Blufftown formation for the upper part of the Eutaw formation (the Tombigbee sand nember, as defined by Stephenson, 1911, pl. 5) and restricting the name Eutaw to the strata between the Tuscaloosa and Blufftown. Cooke (1943, p. 13) extended this usage into Georgia.

Areal extent.-The Eutaw formation, the lowest formation of Cretaceous age definitely of marine origin, crops out along a narrow belt from the Chattahooche River to the Flint River. East of the Flint River it forms the base of a sequence of rocks so similar lithologically that the Eutaw and the overlying rocks up to the base of the Ripley formation cannot be differentiated. Therefore, the Eutaw formation as a distinct and mappable unit cannot be traced east of the Flint River, and the northeasternmost point at which beds of Eutaw age crop out continuously is not known. Strata immediately above the Tuscaloosa formation from the Flint to the Ocmulgee Rivers, however, have been tentatively assigned to the Eutaw.

The belt of the outcrop of the Eutaw narrows from about 7 miles in the Chattahoochee River valley to about 2 miles in the Flint River valley. The outcrop on the upland between these valleys is about a mile wide except where outliers of the Eutaw cap a series of hills north of the main body of the formation, as in Muscogee and Taylor Counties. These outliers extend the area in which rocks of the Eutaw formation are found several miles to the north. 
Lithologic character.- The Eutaw formation is distinctly marine in the Chattahoochee River drainage area, but from northwestern Marion County eastward the formation loses its definitely marine characteristics. Borings of the supposedly marine organism Halymenites major are found as far east as the Marion-Chattahoochee County line and are in a rock type that continues indefinitely eastward.

Down the dip in the Chattahoochee Valley the formation consists of two conformable units: a basal sand, generally coarse and containing Halymenites borings, and an upper dark-gray shale interbedded with fine white sand (fig. 2). The shale contains a profusion

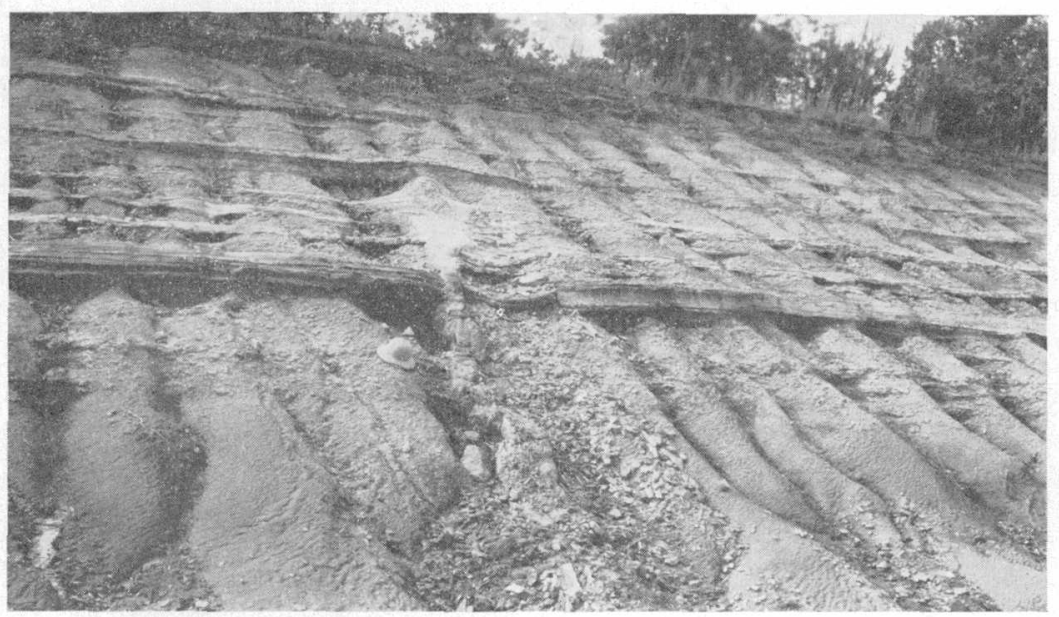

Figure 2.-Fissile and brittle dark-gray clay containing thin beds of white sand typica] of the upper part of the Eutaw formation in the Chattahoochee River valley. A sandstone "dike" is in the center of the picture. Note a slight sag in the sand beds to the right of the "dike" just below where the "dike" ends abruptly. Cut north of U. S. Highway 241, 0.6 miles southwest of Uchee Creek, Russell County, Ala., about 6 miles west of the Chattahoochee River.

of thin shells of mollusks and other fossils; it is firm, compact, and fairly resistant to erosion, although slippery when wet. Tests on the clay from this formation in Alabama show that it is montmorillonitic and that some of it has much of the quality of bentonite.

Toward the east and north, the shale and fine sand give way to coarse sand in a remarkably abrupt change of facies. Within 10 miles or less of the Chattahoochee River all except the uppermost few feet is sand, weathering pale reddish brown, which has been confused with the underlying Tuscaloosa. The structural maps (pl. 3) showing contours on the horizons immediately above and below the Eutaw have been helpful in determining the boundary where the outcrops are 
in question, but there are also distinctive lithologic differences. In general, the sand of the Eutaw formation weathers to a somewhat deeper shade of red or reddish brown than the Tuscaloosa. In addition, the Eutaw generally contains white kaolinitic clay balls and lenses, and its clays are not as intensely mottled with purplish red as those of the Tuscaloosa. The sands of the Tuscaloosa are also generally more gravelly throughout than the sands of the Eutaw. Because the basal sand of the Eutaw also contains fine gravel, the two are frequently difficult to distinguish at their contact. Generally, however, the top of the Tuscaloosa contains a bed of intensely mottled clay several inches to several feet thick, and the basal Eutaw, consisting of sand and fine gravel, irregularly overlies this bed of clay.

Beds presumed to be of the Eutaw formation have been distinguished from the Tuscaloosa as far east as the Ocmulgee River in Bibb County. East of the Ocmulgee the two formations become less distinguishable, and considerable evidence exists that the Eutaw and overlying formations completely overlap the Tuscaloosa in updip areas. The rocks of eastern Georgia, which may include beds of Eutaw age, are further discussed under the heading "Undifferentiated Cretaceous rocks."

Thickness.-The Eutaw formation is about 125 feet thick in the Chattahoochee River valley. In Russell County, Ala., a few miles west of the river, the basal sand ranges from 10 to 60 feet in thickness and the overlying shale from 65 to 115 feet. Up the dip the sand is thicker and the shale is correspondingly thinner. East of the Chattahoochee, in the Harmony Church area of Fort Benning, the Eutaw is about 100 feet thick. In northern Marion County, south of Juniper Creek, where most of the Eutaw formation has been exposed in new cuts for a quarter of a mile along State Highway 41, the thickness is about 85 feet. The formation continues to thin toward the east, but as it cannot be distinguished from the overlying Blufftown formation east of the Flint River, the exact thickness of its correlative in central and eastern Georgia is not known.

\section{IOCAL DETAILS}

Muscogee County.-The high hills of the southern part of the county, elongate to the north and south, are capped with outliers of the Eutaw formation. A few have a thin, small remnant of sand of the Blufftown formation on top and thus possess a complete section of the Eutaw formation. Two such hills are on either side of U.S. Highway 27 through Fort Benning-one north, the other south, of the Benning Hills residential district. The Blufftown is not well exposed on either 
hill, however, and its identification there was based mainly on soils and topography. On a high hill a mile north of the Sand Hill area military outpost, on an extension of Columbus Avenue to the southeast, about 20 feet of massive red coarse sand of the Blufftown overlies clayey fine sand of the Eutaw, and about 135 feet down the hill the basal sand of the Eutaw formation, 17 feet thick, overlies pale clayey coarse sand of the Tuscaloosa. Half a mile west, in a cut bank on the east side of the Central of Georgia Railway, 12 feet of basal sand of the Eutaw, red and crossbedded, overlies 15 feet of pale clayey coarse sand of the Tuscaloosa (fig. 1A). Just west of this exposure, on the old Columbus-Cusseta highway, the basal sand of the Eutaw formation consists of 10 feet of white compact sand overlying 2 feet of clayey coarse sand which contains ironstone and fossil prints and grades downward into coarse loose sand.

A nearly complete section of the Eutaw formation is found along U. S. Highway 27 southeast of Columbus, beginning at the base of the formation near the traffic circle from which the main road to Fort Benning branches from the highway. Variegated clays of the Tuscaloosa formation are found in a gullied highway ditch at the traffic circle, but about 20 feet up the hill is clay shale that contains abundant prints of thin-shelled mollusks. This material continues from one cut to another up the hill to the vicinity of Benning Homes where, just east of the highway, is sandy soil presumably derived from the Blufftown formation. The clay contains occasional lenses of white to pale-gray fine sand from 1 to several inches thick.

Excellent collections of fossils from near the base of the Eutaw can be obtained from exposed bluffs north of Upatoi Creek, south of the Post Cemetery at Fort Benning, in the southwest corner of the county. These exposures were formed a few years ago by landsliding caused by the cutting of a ditch for a sewer line. Shells of Ostrea cretacea, Exogyra upatoiensis (type locality is a few miles east in the same creek valley), and Anomia argentairia are especially abundant, and a number of other fossils are present.

Other excellent exposures of the Eutaw formation in the vicinity of Fort Benning are along St. Marys and Moye Roads. Just south of the intersection of these roads, nearly a mile north of the eastern limits of the Sand Hill area, are excellent exposures of the conformable contact of the bentonitic and fossiliferous fine sands, clays, and silts, with the coarse crossbedded Habymienites-bored basal sand of the Eutaw. The contact here is sharp and marked by an ironstone layer. A short distance north of the intersection, and a few feet 
lower, in cuts west of the Moye Road, the coarse basal sand of the Eutaw irregularly overlies purplish-red massive sandy clay of the Tuscaloosa.

On St. Marys Road 11/2 miles west of the above intersection is a high hill capped with coarse red sand and ironstone of the Blufftown formation; the contact between the two is at an altitude of about 500 feet. A third of a mile west and about 100 feet lower is the contact between the Eutaw and the Tuscaloosa formations. This contact is well exposed also along Steam Mill Road and Buena Vista Road (State Highway 103).

To the north and east of Fort Benning the coarse sand of the Eutaw increases markedly in thickness at the expense of the clays and silts. In the southern part of the county the basal sand is only a few feet thick but in high outliers in the central and eastern parts of the county it is at least 40 feet thick, perhaps more, as the top of the sand is generally not well exposed. Some of the best exposures of this thick lower sand of the Eutaw are along northward-trending Schatulaga and Moye Roads near eastward-trending Buena Vista Road. A sandpit north of Buena Vista Road, 0.2 mile west of its intersection with Moye Road, shows 40 feet of very-pale-reddishbrown crossbedded coarse to fine sand containing a few bentonitic layers and balls and layers abounding in borings of Halymenites. Although the sand somewhat resembles that of the Tuscaloosa to the west, especially in central and western Alabama, the marine borings reveal that it is of the Eutaw. Downhill in nearby cuts the palepurplish-red and white mottled massive beds of the Tuscaloosa show the contrasting nature of the sediments of the two formations in this region.

Chattahoochee County.-In all except the northeast corner of the county, the outcrop of the Eutaw formation is relatively far down the dip and topographically low. In this county the larger part of the outcrop of the formation is in the banks and valley walls of the Chattahoochee River, Upatoi Creek, and their tributaries, and consists largely of fossiliferous clays and silts and a relatively small percentage of sand. In the northeast the formation is on the higher hills where it consists largely of sand. In the vicinity of Fort Benning it has been covered generally by alluvial deposits of Pleistocene age, but a late Pleistocene-to-Recent rejuvenation of the Chattahoochee has caused that stream and nearby reaches of its tributaries to cut through the alluvium and expose the Eutaw. This downcutting is apparently still progressing, and rapids, shoals, and steep bluffs appear along the course of the river. "Rocks," "narrows," and "passes" 
are local geographic terms inherited from the days of river transportation and reflect the character of the river and its banks. The almost straight reach southeast from the broad bend at Lawson Field, Fort Benning, is in a narrow channel. Uchee Rapids in this reach were cut in the firm and fairly resistant, although slippery, clay of the Eutaw formation. Bordering this reach on the southwest (Alabama) side of the river is the rugged Slick Bluff rising more than 200 feet above the river. Veatch and Stephenson (1911, p. 120-121) have described the landsliding, as well as the lithologic features, of these bluffs. The greenish-gray clays contain a few thin beds of sand and, in places, sand "dikes." According to McCallie (1903), the "dikes" were formed shortly after the clays were laid down. He attributed them to slippage during eathquake movements, which squeezed sand, from beds that had not hardened, into fractures. Similar "dikes" were observed by the writer in clays of the Eutaw formation in Russell County, Ala., on newly exposed cuts on U. S. Highway 241, half a mile southwest of Uchee Creek (fig. 2).

The basal beds of the Eutaw are well exposed at Broken Arrow Bend on the Chattahoochee River, 1 mile west of the Fort Benning post office. Beds that contain abundant shells of Ostrea cretacea occuir near the Post Cemetery, 2 miles northeast of the Fort Benning post office, about 30 feet above the base of the formation. The contact between the Eutaw and the Tuscaloosa, near the water level at the time of this survey, is about 180 feet above sea level, the lowest altitude at which this contact has been found on the surface. Stephenson (1911, p. 117-118 and pl. 8a) describes the basal coarse sand of the Eutaw formation here as being from 2 to 13 feet thick and containing lignite, petrified wood, and leaves in a black clay 8 inches thick. Fossiliferous laminated calcareous sand extends 15 feet above the coarse sand and contains shells of Ostrea cretacea.

One of the most significant exposures of the Eutaw, especially of the basal 30 or 40 feet, and of the contact with the Tuscaloosa beds below, is in cuts south of the bridge over Upatoi Creek on the military road just east of U. S. Highway 27. This is very near the site of a section described by Stephenson (1911, p. 126) and redescribed by Cooke (1943, p. 15), a quarter of a mile below the bridge of the Columbus-Cusseta road. A part of the coarse sand of bed 2 of Cooke's section is here assigned to the Eutaw because of the presence of Halymenites borings and because the contact with the underlying Tuscaloosa is now plainly exposed. The section redescribed is as follows: 
Scction on hill south of Upatoi Creek, in a cut on the east side of the military road that parallels U. S. Highuay 27, about 1. mile southeast of Sand Hill area of Fort Benning

Wutaw formation:

Feet

Sand, very fine, clayey, gray, micaceous, carbonaceous, hackly ; somewhat fissile on weathered surface; weathers to buff or tan ; contains flattened lignite logs as much as 30 inches wide and abundant prints of thin shells of mollusks; more clayey toward base, generally, but in lower 7 feet are several layers of fine purer sand averaging about 6 inches in thickness. Exposed from top of cut

Sand, coarse, clayey; contains feldspar grains as much as 1 centimeter in iliameter, some subangular quartz grains as much as nearly I centimeter in diameter, and abundant shell prints; generally more ferruginous than beds above and below. Upper contact is sharp, but base is undulating and grades into bed below

Sand, coarse, white to tan, loose, strongly and steeply crossbedded; abundant borings of Halymenites major near top; contains clay balls and feldspar and quartz grains generally less than 1 centimeter in diameter; some very thin clay beds in the crossbedding. Basal 6 to $S$ feet is subrounded quartz gravel with pebbles as much as 1 centimeter in diameter; base is a highly irregular ferruginous conglomerate 3 to 10 inches thick

'l'uscaloosa formation:

Sand, clayey in upper foot or more, yellow to gray ; grades downward into coarse sand, white to pale-yellow-stained, with quartz and some mica and feldspar granules as much as 5 millimeters in diameter

Clay, fairly sandy, light-gray, stiff, massive; yellow-stained at top; irregular in thickness. Grades into bed below

Sand, coarse, white, crossbedded, loose, micaceous. Exposed to about 5 feet below level of old bridge and about 15 feet above bottom of Upatoi Creek

Three miles east of this locality about 50 feet of clay and sandstone of the Eutaw formation, containing many shells and prints of mollusks and cephalopods, forms shoals in the bed of Ochillee Creek near the old Ochillee Station. The section was originally described by Stephenson (1911, p. 129) and redescribed by Cooke (1943, p. 16). During the present survey about 15 feet of assorted clay and pale coarse sand of the Tuscaloosa formation was found immediately downstream from the shoals, although the contact between the Eutaw and Tuscaloosa has been obscured by landsliding. About half a mile south and 97 feet (by altimeter) above the contact between the Eutaw and the Tuscaloosa formations in the bed of Ochillee Creek, the contact between the Blufftown and Eutaw is exposed in cuts on First Division Road. The Eutaw is, therefore, about 100 feet thick in this vicinity.

In downdip areas clays of the upper part of the Eutaw formation are overlain sharply by coarse irregularly crossbedded sands of the $399546-55-3$ 
Blufftown formation. In the northeastern part of the county, however, the relations between the Eutaw and the Blufftown formations are not clear, and little distinction can be made between their sedimentary rocks. In that area the Eutaw is mostly coarse sand with a few thin beds of carbonaceous clay, and the basal Blufftown is coarse sand generally without distinctive beds of clay. Deep weathering of the sands has produced a mantle of sandy soil that has crept down hillsides, obscuring bedrock and obliterating exposures of contacts. These large rolling uplands and steeper valley walls form the westernmost sandhills, a distinctive topographic and geographic feature typical of the upper Coastal Plain of several States from here northeastward. The soils of deep sand favor underground drainage, so that all except the most intense rainfalls soak into the loose sand. Accordingly, strong flows of ground water emerge as springs in the valley 100 to several hundred feet below the uplands. Streams of the sandhills are remarkable for their clarity, purity, and regularity of flow. Because of the high rate of infiltration of rainfall into the soil, ferruginous matter, aluminous clays, and other compounds have been leached from the soil and upper layers of bedrock and are generally redeposited at lower levels nearby. This leaching has resulted in numerous shallow depressions and intervening sandy mounds on rolling uplands which have been mistaken for dune topography. The author believes that the amount of blowing sand has been negligible in this area and that the country has never been bare enough of vegetation to allow extensive dunes to form on the uplands. L. L. Smith (1931) has shown that it is possible for such depressions to form entirely by leaching processes. A large area of such topography and deep sandy soil is in northeastern Chattahoochee County in Fort Benning Military Reservation.

Marion County.-One of the most significant exposures in the interpretation of the Cretaceous of western Georgia is on a county road 0.3 mile east of the Chattahoochee-Marion County line (east-central part of the Buena Vista NW quadrangle). In road cuts and gully walls, pale sand underlying mottled clay suggests the lithologic character of the Tuscaloosa farther west but contains distinct borings of Halymenites major. This exposure, therefore, shows that although the Eutaw formation resembles the Tuscaloosa it is nevertheless marine and has distinguishing features this far east. Structurally, too, it could hardly be considered Tuscaloosa, because it is about 100 feet higher than the expected top of the Tuscaloosa formation as indicated by projecting contours from better exposed localities to the west. Overlying the Eutaw is an extensive section of pale coarse sand of the Blufftown formation. The following section was recorded: 
Section 0.7 to 0.3 mile southeast of Pine Knot Creek, east of the Chattahoochce-Marion County line

Blufftown formation :

Feet

Sand, very coarse; contains rounded fine pebbles of quartz at base, and much tubular ironstone. Altitude of base, about 540 feet._.--

Clay and coarse sand; contains coarse-sand and clayey-sand lenses. About

Covered; exposures 11/2 miles south show silty carbonaceous clay containing sand lenses in this interval. About

Sand, fine to coarse, coarse sand at base. Average altitude of base, 434 feet. About.

Unconformity.

\section{Eutaw formation:}

Clay, pale-purple and gray, mottled. About

Sand, clayey, very hard, pale gray grading downward into pale red; contains fine gravel. About

Sand, very coarse, crossbedded; contains distinct borings of Halymenites major 4 feet above a silicified $\log 27$ feet long and as much as 2.6 feet in diameter broken into 6 ssections 3 to 7 feet long; log is in very friable sand in gullied road ditch and has partially fallen into gully.

Taylor County.-The Eutaw formation crops out in Taylor County in a narrow band through the north-central part of the county. Generally the contact with the underlying Tuscaloosa formation can be recognized in the valley of Patsiliga Creek, but north of this creek the Eutaw, capping the long, high ridges between the drainage lines of Timms and Little Patsiliga Creeks, becomes increasingly difficult to distinguish from the overlying and underlying formations. The previously described exposure of the probable basal Eutaw and uppermost Tuscaloosa, a quarter of a mile south of Timms Creek on U. S. Highway 19, is typical of this contact in the area. Another good exposure is about a half a mile south of Suggs (Old Anthony) Mill, about $51 / 2$ miles east-northeast of Butler on a tributary of Little Patsiliga Creek; 15 feet of pale-brown gravelly sand of probable Blufftown age lies on massive silty and sandy gray clay that grades downward into sand and gravel of the Eutaw formation. Downhill to the north variegated clay of the Tuscaloosa is exposed.

Crawford and Bibb Counties.-Although the Tuscaloosa formation east of the Flint River is overlain by material similar to that west of the river, the Eutaw formation (?) cannot be distinguished definitely from the overlying Blufftown. The section tentatively assigned to the Eutaw is coarse sand with a minor amount of white, in places slightly purple-mottled, clay. Two miles south of Roberta on State Highway 7 a gravel and sandpit east of the highway shows the color of relatively unweathered material of the Eutaw formation (?), in contrast to the weathered colors. In this pit tan to white sand containing fine gravel and clay balls overlies very-pale-lavender 
clayey crossbedded sand. In a weathered exposure nearby, this latter bed is distinctly mottled with tan.

. In the southwestern part of Macon, sand and gravel of probable Eutaw age are well exposed in pits three blocks south of Anthony Avenue on a westward extension of Key Street. The sand is pale reddish brown, conspicuously crossbedded, and contains scattered pebbles and gravel lenses of quartz pebbles as much as 1 inch in diameter.

\section{BLUFFTOWN FORMATION}

GENERAL FEATURES

Name.-The Blufftown formation was named by Veatch (1909, p. $86,88-89)$, who defined it as the basal subdivision of the Ripley formation, overlain by the Cusseta sand and underlain by the Eutaw formation. The history of the terminology applied to the beds of the Blufftown is intimately associated with that of the Eutaw.

The lower part of the Eutaw exposed on Upatoi Creek (in western Georgia) contains Exogyra upatoiensis, Ostrea cretacea, and abundant other fossils, though farther west in Alabama and Mississippi there are scarcely any fossils in the lower part of the Eutaw. On the other hand, the Tombigbee sand member, at the top of the Eutaw, contains many fossils, including Exogyra ponderosa. Stephenson (1911, p. 143 ) assumed that the E. upatoiensis fauna was older than any other Cretaceous fauna in the East Gulf Coastal Plain. As a result, he called the fossiliferous Blufftown formation the Tombigbee sand member of the Eutaw formation, because the Blufftown contains a sand-facies fauna similar to the fauna of the Tombigbee sand farther west. Consequently Stephenson $(1911$, p. 135, 145) included the lower part, or perhaps all, of the Blufftown in the Eutaw and called it the Tombigbee sand member. Stephenson (1914, p. 25) later found Exogyra upatoiensis in the Tombigbee sand near Montgomery, Ala. In 1938 Stephenson and Monroe (1938, p. 1648) showed convincingly that the Blufftown formation grades westward into the lower part of the Selma chalk and the Eutaw grades westward into the main body of the Eutaw formation, probably into the upper part. Thus the name Blufftown formation was revived and now designates the strata of early Selma age between the Eutaw formation and the Cusseta sand.

The thick basal sand of the Blufftown formation, originally included by Stephenson (1911, p. 114, 131-140) in the Tombigbee sand member of the Eutaw formation, lies immediately on dark shales of the Eutaw formation in a sequence of beds similar to those in central and western Alabama. Later, Stephenson and Thompson (1943, unpublished report) and Cooke (1943, p. 18-19) assigned this sand to the Blufftown, but recently Ray (unpublished report), in his study of the geology of Fort Benning, has placed it again in the Eutaw. 
Areal extent.-The Bluftitown formation grades laterally into the Mooreville chalk and the basal part of the Demopolis chalk in eastern Alabama (Eargle, 1950). In Georgia the formation crops out in a belt from the Chattahoochee River valley east-northeastward to the Flint River; east of the Flint River it becomes indistinguishable from the underlying Eutaw formation and the overlying Cusseta sand. The writer: knows of no way to distinguish beds of Blufftown agge in eastern Georgia. The belt of outcrop is unusually wide along the Chattahoochee River because the river flows roughly parallel to the strike of the formation for 16 miles from Chimney Bluft to a point a few miles southwest of Omaha. In western Chattahoochee County and northcentral Stewart County the formation has a width in the lowland of about 8 miles. In the Flint River valley the width of the belt of outcrop is only about $11 / 2$ miles. This narrowing of the belt is due in part to thinning of the formation toward the east but may also indicate some overlap by the Cusseta sand. Too, beds of fine sand in the upper: part of the Blufftown become coarse in an easterly direction from eastem Chattahoochee County and thus become difficult to distinguish from the Cusseta sand.

Lithologic character.-In the Chattahoochee River valley the Blufftown formation consists of a basal unit of crossbedded coarse sand, about 150 feet thick, overlain by laminated more or less sandy carbonaceous highly micaceous fossiliferous clay, about 260 feet thick. Toward the east the upper clay member rapidly grades laterally into unfossiliferous coarse sand that is difficult to distinguish from either the basal sand member or the overlying Cusseta sand. In central Georgia between the Flint and Ocmulgee Rivers the outcrop of the Eutaw, the Blufftown, and the Cusseta formations forms a wide belt of rather featureless sandhills characterized by a heavy mantle of leached sand with very few exposures of unweathered material.

The basal sand forms the conspicuous ridge across central Russell County, Ala., that Monroe termed the Sand Fort Cuesta (1941, p. 35). It produces the high sandhills of the Harmony Church area south of Upatoi Creek in Fort Benning Military Reservation. Up the dip, the high, rolling sandhills of the northeastern part of the reservation and the extensive sandhills of northern Marion County are underlain partly by this sand.

Ledges of the basal sand cemented by iron oxide form most of the landmarks such as' Moores Rocks, Beton Rocks, and Codys Rocks along the almost straight reach of the Chattahoochee River below Uchee Creek southeast of Fort Benning. The top of this basal sand is exposed in Chimney Bluff at the first sharp bend on the Chattahoochee River southeast of Fort Benning. The contact with the overlying laminated clays is uneven. For the next several miles down the valley 
the river channel is confined to steep banks of this sand in which are numerous ledges and concretionary masses of resistant calcareous sandstone.

From Big Bend in southwest Chattahoochee County to the Blufftown bluffs in northwestern Stewart County most of the bank exposures are in laminated clay that contains numerous fossiliferous ledges. Locally the beds are very sandy, as at Snake Shoals, 1 mile northwest of the Blufftown bluffs, where molds of large ammonites are embedded in calcareous sandstone ledges, and numerous spherical concretions project from banks of clayey sand. Toward the top of the bluffis near the site of old Blufftown, northwestern Stewart County, the type locality of the formation, fossiliferous silty clay containing thin beds of very fine sand grades upward into fine sand.

One mile west of the town of Cusseta the upper 25 feet or less of the Blufftown formation consists almost entirely of very micaceous fine sand extensively bored by Halymenites major. Near the town of Cusseta the contact of fine sand of the Blufftown with the overlying coarse sand of the Cusseta can be seen in several places. About 21/2 miles east of Cusseta, coarse sands appear in the upper Blufftown. Farther east the coarse sands occur at increasingly lower positions in the section, so that the entire Blufftown formation and the overlying Cusseta sand becomes nearly indistinguishable through most of Marion and Taylor Counties.

At several places in Taylor County, however, coarse sand and ferruginous conglomerate lie on fissile carbonaceous clay at what appears to be the contact of the Cusseta sand and the Blufftown formation. The clays, containing plant fossils only, resemble the clays of the Blufftown in the Chattahoochee River valley. They probably represent a nearshore or lagoonal depositional environment rather than a definitely marine one. In this study they are correlated with the clays of the Blufftown although the two areas are separated by many miles of high ridges of Cusseta sand in Marion and western Taylor Counties. A few inliers of the Blufftown type of dark-gray fissile clay in Marion County tend to support this correlation. The Blufftown clays are believed to extend to the northern slopes of these sandhills, but they are not exposed because of deep weathering and the development of a thick residual sand chiefly by leaching. Their approximate position is indicated by a flat steplike bench a mile or more wide on the north-facing cuesta. This bench is not prominent but can be traced for a number of miles through northern Marion County to central Taylor County.

Between the Flint and Ocmulgee Rivers the Eutaw, Blufftown, and Cusseta formations are lithologically indistinguishable and are not differentiated on the geologic map. 
Thickness.-Beds of the Blufftown, the thickest of all outcropping Cretaceous formations in western Georgia, total about 410 feet in thickness in the Chattahoochee River valley. In that area the basal sand is about 150 feet thick and the overlying predominantly clay section is 260 feet thick. As the Blufftown cannot readily be distin. guished from the underlying Eutaw formation or overlying Cusseta sand in central Georgia, and as the combined thickness of all 3 formations is only 300 to 400 feet in this area, the eastern extension of the

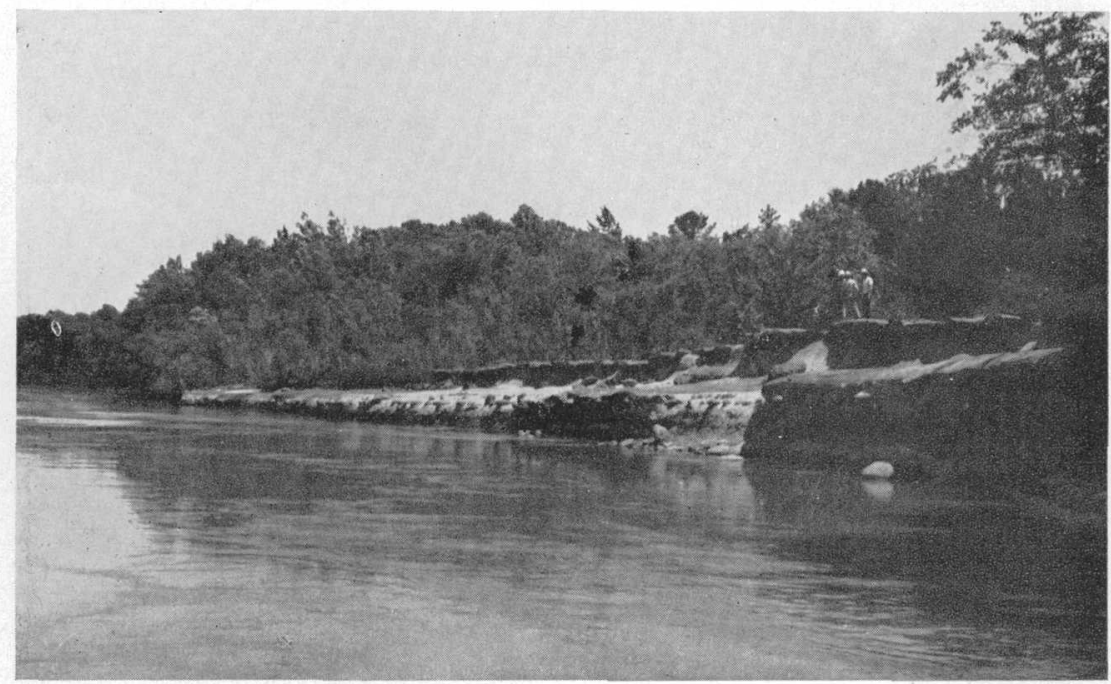

Figure 3.-Clayey sand of the upper part of the Blufftown formation containing discontinuous layers of calcareous concretions and ammonites. Alabama side of the Chattahoochee River near Snake Shoals, 1 mile upstream from the type locality of the Blufftown formation, in the northwestern corner of Stewart County, Ga.

Blufftown must be much thinner than in the Chattahoochee River area unless, as seems unlikely, the other 2 are very thin, absent, or cut out by overlap.

\section{LOCAL DETAILS}

Stewart County.-Down the Chattahoochee River from the mouth of Hichitee Creek, where the Stewart-Chattahoochee County line meets the river, the rejuvenated river has cut vertical banks in the massive clay of the Blufftown formation. In high bluffs in the northwestern part of Stewart County, below the site of the old Banks Landing, elliptical concretions are found in the sandy clays. Downstream from this point, on the outside of a wide bend projecting toward Alabama at Snake Shoals, discontinuous ledges of calcareous sand containing ammonites and elliptical concretions cap near-vertical banks of clayey sands (fig. 3). Sir Charles Lyell, on his second trip to the 
United States in 1846, saw in Columbus a collection of fossils from this site and identified them as Cretaceous (1849, p. 33).

East of these shoals, and downstream, are-bluffs over 200 feet high consisting of very fossiliferous gray clay that grades upward into clayey sand. These high banks constitute the type locality of the formation, 0.2 mile west of the old home that was once the post office of Blufftown. The whole settlement had been abandoned before the time of this survey, but the house is shown on the Julia quadrangle at the end of a secondary road a mile southwest of the Upper Bradley Place. Herrick (personal communication) has recently studied the fossils and stratigraphy of these bluffs.

Beneath the bridge leading into the Upper Bradley Place a very fossiliferous dark-gray micaceous clay containing fine sand represents a part of the same section that is exposed in the bluffs at the type locality and is more accessible than the bluffs. Forty feet higher is a 60 -foot bed of fine-grained sand that weathers red, above which is clay containing fine sand. This sandy clay, in turn, grades upward into fine sand and thin beds of clay on which, east of the bluffs, coarse sand of the Cusseta lies. Some other published sections of the bluffs of the type locality designate the upper beds of fine sand as Cusseta (Cooke, 1943, p. 22). The basal Cusseta, however, is generally coarse sand and can be traced upstream from classic localities, where the unconformity is well exposed and unmistakable, and is marked with unusually coarse sand, waterworn shells of large fossils, logs of silicified and lignitized wood, and other debris.

The beds found in the bluffs just downstream from Florence, Ga., are now believed to be of the Blufftown formation, although 30 feet of the section there, consisting of micaceous very clayey fine sand, has previously been assigned to the Cusseta sand (Cooke, 1943, p. 25).

Chattahoochee and Muscogee Counties.-The Blufftown formation occupies most of Chattahoochee County, although north of Upatoi Creek, in the southern part of Muscogee County, only a few hills are high enough to retain outliers of the formation. It makes up the greater part of the rolling sandhills that characterize Fort Benning Military Reservation. In the western part of Chattahoochee County, thick coarse to gravelly sand of the basal member overlies, perhaps unconformably, clays of the Eutaw formation. In the channel walls of the Chattahoochee River about $51 / 2$ miles southeast of Fort Benning headquarters and $11 / 2$ miles south of the mouth of Uchee Creek on the Alabama side, this basal bed is 3 feet thick and is a hard generally fine-grained white sandstone containing a few coarse grains of quartz and some round pebbles of clay and lignite. Fossil shells are rarely seen in the basal sand of the Blufftown. 
An almost continuous section is well exposed for several miles in the deeply cut walls of the Chattahoochee River from Chimney Bluff, opposite the first sharp bend in the river southeast of Fort Benning, to the southwestern corner of the county. The section at Chimney Bluff includes a large part of the Blufftown formation as interpreted during this survey. The upper and larger part of the bluff, down to within about 12 or 15 feet of water level, is dark-gray silty clay and fine sand that locally is very fossiliferous. At the base of the clayey section is a 6 -foot layer of dark tough clay whose base forms

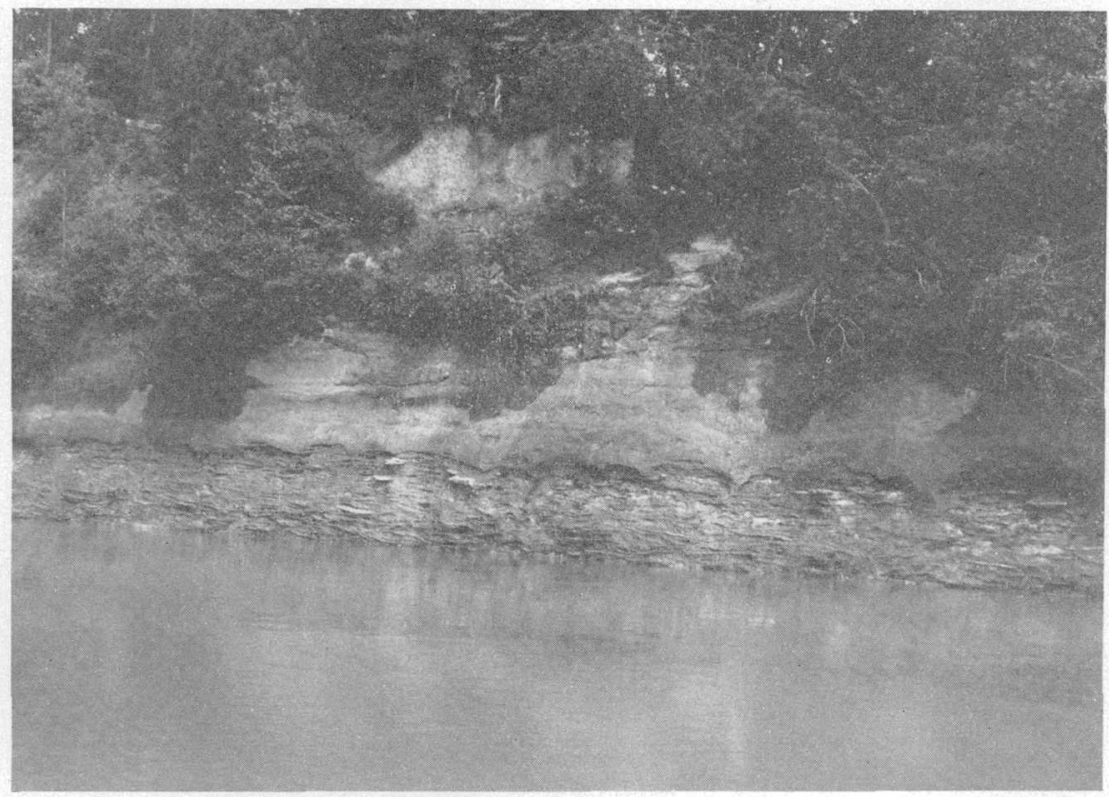

Figure 4.-Massive dark-gray silty clay of the upper part of the Blufftown formation lying irregularly on laminated erossbedded sand of the basal member. Left bank of the Chattahoochee River at Race Passes, 1 mile east of Big Bend and 1 mile southwest of Chimney Bluff, southwestern part of Chattahoochee County.

scallops that project downward into loose sand below at fairly regular intervals of about 15 to 25 feet. This loose sand contains subordinate clay laminae and is the upper part of the basal sand of the formation (fig. 4).

This contact of upper clay and lower sand of the Blufftown formation persists through Race Passes, a narrow reach of the river in which the swift current is confined for half a mile or more between vertical walls that start about a mile downstream from Chimney Bluff. As the river almost parallels the strike of the formation here, the contact persists to and beyond Big Bend, a horseshoe bend whose convex side projects toward Alabama. From Planters' Landing, a 
mile upstream from the southwest corner of the county, the vertical channel walls are composed of tough clay. Downstream from here the bluffs continue past the mouth of Hichitee Creek into Stewart County.

Up the dip in Chattahoochee County, the basal sand of the Blufftown is exposed at a number of places along 1st Division Road east of Fort Benning headquarters. In several places near the crest of this upland, red coarse sand, with borings, irregularly overlies very fine laminated micaceous clayey sand containing some thin clay beds. All this is of the Blufftown formation, the base of which is believed to be more than 50 feet below and overlain by terrace gravel in the eastern part of the headquarters area of the fort.

Several good exposures of the basal sand may be seen along U. S. Highway 27 through the Harmony Church area of Fort Benning. The basal contact of the Blufftown extends through several cut banks half a mile to a mile northwest of the overpass of 1st Division Road over U. S. Highway 27. The best exposure seen, however, is in a bank along Marne Road at the underpass under U. S. Highway 27, 1.2 miles northwest of Harmony Church area. Here coarse sand containing fine gravel overlies laminated clay and sand of the Eutaw formation. The contact is faulted at this point, possibly due only to surficial movement.

The base of the Blufftown becomes increasingly difficult to locate toward the eastern part of the Fort Benning reservation, owing chiefly to the deep weathering and downhill creep of the loose sand over the underlying clayey beds of the Eutaw. In addition, the Lutaw, except for the uppermost few feet, also becomes mostly sand, and its contact with the Blufftown becomes obscure even where well exposed. A distinct contact, however, is found where ferruginous conglomerate and sandstone of the Blufftown overlies fine sand of the Eutaw in a cut on U. S. Highway 103, about a mile southeast of Pine Knot Creek.

Along the numerous trails and roads of the fort are extensive areas of Blufftown clay and sand. The thick basal sand of the Blufftown formation, forming the high hills on which the Harmony Church area is located, dips gently southward and is capped with dark-gray silty clay. In the southern part of the area of outcrop of Blufftown this clay constitutes the soil of most of the county; it is difficult to build roads on or even to traverse in wet weather. Along the north-facing billside on Jamestown Road south of Weems Pond about 130 feet of this clay can be seen below the contact of the coarse sand of the Cusseta sand (for a described section here, see Stephenson, 1911, p. 140 ; Cooke, 1943, p. 19). 
A good exposure of the contact of the clayey upper member and the sandy lower member of the Blufftewn is in a sandpit east of U. S. Highway 27, 31/2 miles south of the Harmony Church area and 1 mile southeast of where Hourglass Road, the southernmost viaduct of Fort Benning military roads over the highway, crosses it. The following section was measured there:

Section 31/2 miles southeast of Harmony Church area, 1 mile southeast of a viaduct over $U$. S. Highway 27, in a sandpit east of the highuay

Soil, red, sandy and silty. About

Blufftown formation (upper member) :

Sand, fine; contains some thin clay laminae; slightly faulted along joint planes; ironstone concentrated along joint planes and fault lines, the most conspicuous of which are parallel, 2 to 3 feet apart, and trend southeastward; banded weathering within the jointed blocks. Grades downward into more clayey material in lower 4 feet. Maximum.

Clay, fissile, and fine sand, hackly surface, micaceous, carbonaceous; contains borings. Sharp basal contact, altitude approximately 360 feet.

Blufftown formation (lower member) :

Sand and granular conglomerate, upper part ferruginous ; quartz sand grains as much as one-fourth inch in diameter; grades downward into fine crossbedded sand. Exposed, about.

In cuts a quarter of a mile south of the foregoing section, and 10 to 40 feet stratigraphically higher, beds of the gray clayey sand and sandy clay are tilted and apparently faulted.

One of the better exposures of a thick section of the marine clay of the upper part of the Blufftown, well suited for collecting fossils typical of these beds, is a deep cut on the west side of U. S. Highway 27 about a mile southeast of the section described above, about $21 / 3$ miles northwest of the town of Cusseta (fig. 5). In this cut the laminated and fissile clay shale grades upward into a very fine sand having only a low clay content. Shells typical of the lower part of the Selma group, such as Exogyra ponderosa, Anomia argentaria and Gryphaea sp., are abundant. About a mile west of Cusseta, very fine micaceous sand having prints of fossils grades downward into dark-gray sandy clay in cuts on the east side of the highway. South of the sharp bend where the highway leading to Cusseta swings from southeast to east, where the soil has been stripped along a projected highway realinement, the uppermost sand of the Blufftown is crowded with borings of Halymenites major. These borings are believed to indicate the shallowing of water near the end of Blufftown time, before the unconformable deposition of the overlying Cusseta sand.

Fast of Cusseta, coarse sand is found in the upper part of the Blufftown formation. On Box Springs Road leading north from State 
Highway 26 to the former Christopher Station on the Central of Georgia Railway, crossbedded very coarse sand overlies fine sand of the upper part of the Blufftown at an altitude of about 440 feet, 40 feet below the base of the Cusseta sand. Both of the beds of sand contain borings. In the vicinity of Ida Vesper, just south of the railroad, cuts along State Highway 26 show considerable coarse sand in the upper Blufitown, and the contact with the Cusseta sand is inconspicuous. Below the cuts, near the abandoned railroad station, is dark-gray clay of the Blufftown.

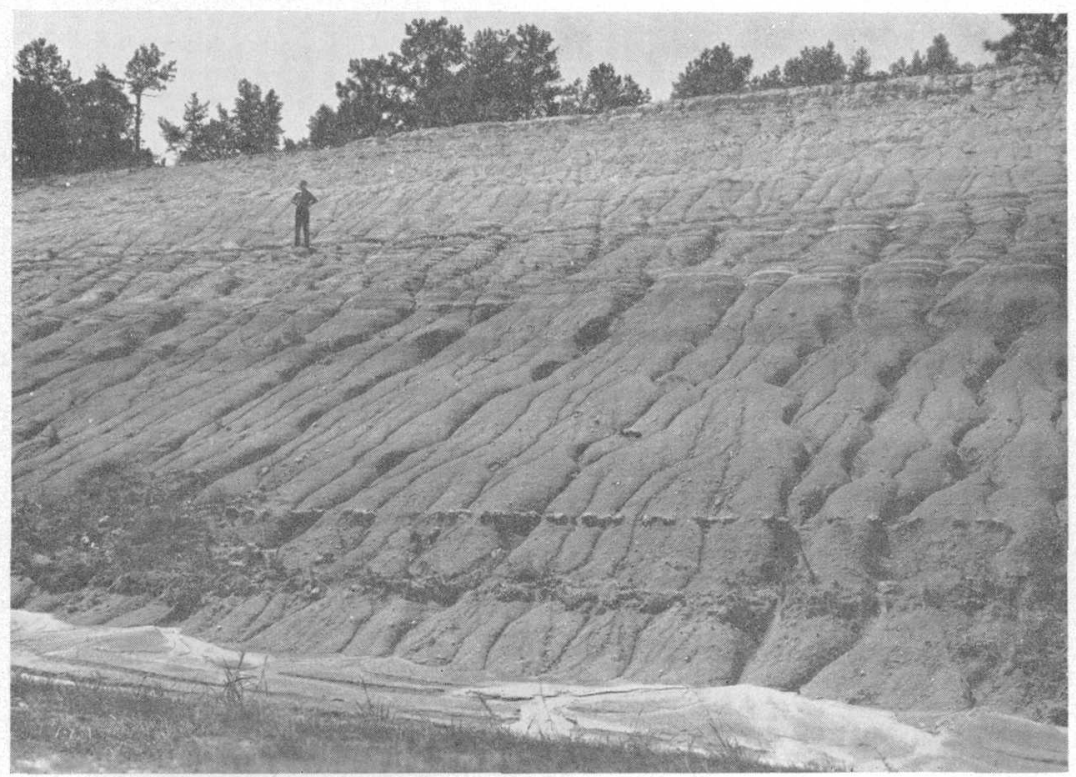

Figure 5.-Typical marine clay and sand of the Blufftown formation. Laminated darkgray fossiliferous marine clay grades upward into fine sand bleached by weathering and soil-forming processes. West side of cut, U. S. Highway 27, 2.3 miles northwest of Cusseta, Chattahoochee County.

Marion County.-The Blufftown formation forms a band along the north edge of the county, mainly on the south valley wall of Juniper Creek and other tributaries of Upatoi Creek. It forms a long projection up Pine Knot Creek in the northwestern part of the county and also a probable inlier in the headwaters of Shoal Creek in the northeast-central part of the county. Its outcrop extends almost up to the highest part of the sandhill area across the northern part of the county. The boundaries are not well marked as the formation is composed mostly of sand. The top of the formation, however, apparently contains a large enough body of clay or clayey sand to produce a bench about a hundred feet or more below the general level of the upland of Cusseta sand. Highway cuts and gullies are hardly 
deep enough to cut through the deep residual sand that blankets the upland. This residual sand creeps down the valley sides, smooths the topography, and forms everywhere a loose mantle of soil, in places as much as 30 to 50 feet thick.

A few exposures show the nature of the parts of the Blufftown. One exposure reported by Cooke (1943, p. 43) and Stephenson and Thompson (1943, unpublished report) is in a pit of clayey road material south of one of the headwaters of Pine Knot Creek, a mile southeast of Parker's Mill, and 500 feet west of the county road, where prints of thin-shelled fossils, chiefly pelecypods, are abundant in clayey fine sand of the Blufftown. This clayey sand is overlain sharply by coarse sand containing fine quartz gravel, probably the basal beds of the Cusseta sand.

On State Highway 41 beds of the basal Blufftown and sections of the Eutaw and Tuscaloosa formations are well exposed. Above the beds of the Eutaw is a sequence of irregularly crossbedded very coarse sand and some pale-purple highly indurated clay with what appear to be borings. This material is probably equivalent to the dark clays of the Bluffitown farther west which have been indurated and bleached by the weathering that has affected most of the carbonaceous clays in the Blufftown, Eutaw, and Tuscaloosa formations in this area.

Taylor and Talbot Counties.--The soils and topographic features produced by the Blufftown formation in Marion County extend into Taylor County and into a small area in southeastern Talbot County. The Blufftown is the source of the material being mined by the Brown Sand Co. at Brownsand, in the southeastern part of Talbot County, and at another pit a mile northwest of Howard in Taylor County. In this area the clays of the Blufftown, as in Marion County, form a distinct bench below the sandhill upland occupied chiefly by the sand of the Cusseta. The outcrop of the Blufftown forms a narrow band across the north-central part of Taylor County, where it is poorly exposed generally. Some of the better exposures of the contact between the Cusseta and the Blufftown, however, and some of the best evidence of the presence of the Blufftown east of western Marion County, are in downdip areas in the deeper creek valleys of Taylor County south of Butler and southwest of Reynolds.

In 35-foot deep pits of the Brown Sand Co. a mile northwest of Howard, slightly ferruginous basal sands of the Blufftown are dug with dragline, dried in rotary kilns, and loaded directly into gondolas or boxcars. The sand is fine to coarse, loose, and finely crossbedded. The extensive mines at Brownsand in the southeastern corner of Talbot County, 21/2 miles southeast of Junction City, are in similar sand that is probably of the basal 100 feet or less of the Blufftown forma- 
tion. White clay lenses near the bottom of this deposit may limit the mining of the sand.

A possible contact of the overlying Cusseta sand with the Blufftown formation is in a sandpit at the crest of a hill along State Highway 96, 4 miles west of Butler and 1 mile west of Mizell. Here, about 3 to 5 feet of somewhat ferruginous fine conglomerate of the Cusseta irregularly overlies very irregularly crossbedded fine to coarse sand of the Bluffitown containing lenses of fissile clay that weathers purplish red. This exposure is at the west edge of the high upland on which Butler is located.

The best observed exposure of the contact of the overlying Cusseta sand with clay of the Blufftown is on a county road leading southwest from Butler toward Charing.

Section on south slope of valley of Whitenater Creck about $5 \frac{1 / 2}{2}$ miles southwcst of Butler in cuts on road toward Charing

Cusseta sand :

Feet

Sand, very coarse to granular, colluvially reworked; contains large boulders of ironstone and granular conglomerate. Sharp basal contact. From top of hill, about

Unconformity.

Blufftown formation :

Clay and sand interbedded; clay weathers yellow (exposed in road-

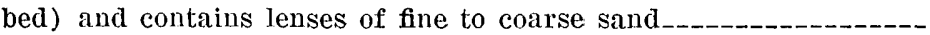

Clay, dark-gray, layered, fissile; weathers ash gray_-_._-_-_-_-_.--

Sand, coarse, ferruginous

Clay, medium-light-gray to medium-gray ; weathers light gray _._._.

Sand, coarse to fine, very-pale orange, crossbedded, ferruginous, generally very micaceous; weathers generally dark yellowish orange to grayish orange; contains a few thin clay beds and white feldspar grains and enough mica to form a crust over weathered surface

At this exposure pseudobedded colluvium from the Cusseta sand up the hill covers the clay outcrops to depths of 12 feet, and material in place is exposed only in the deeper road cuts.

A downdip exposure of the Cusseta and Blufftown contact is on State Highway 137, 1 mile northeast of the Marion-Taylor County line. Here, intermittently exposed downward for about 100 feet from the top of the hill, coarse sand of the Cusseta containing some lenses of white clay overlies 5 feet of ash-gray to white clay of the Blufftown. The base of the Cusseta is a layer of ferruginous conglomerate with quartz granules and pebbles as much as 1 inch long.

In the eastern part of the county are several good exposures of the Cusseta and Blufftown contact. One is $21 / 2$ miles west of Reynolds: two-tenths of a mile northwest of Leona Station on the Central of Georgia Railway, in a ditch on a county road, where several feet of weathered Cusseta sand overlies about 5 feet of fissile white to gray 
silty clay of the Blufitown. The Cusseta sand is slightly disturbed by colluvial reworking and consists of coarse granular ferruginous sand. The clay of the Blufftown lies irregularly on 10 feet of fine crossbedded sand containing fine mica.

An exposure of dark-gray clay of the Blufftown formation underlies terrace deposits and Cusseta (?) sand, 11/2 miles southwest of Reynolds, where L. E. Shirley measured the following section:

Section 1 1 $1 \frac{2}{2}$ miles southwest of Reynolds on a north-facing slope

Quaternary (terrace deposit) :

Feet

Gravel; pebbles up to 2 inches long; overlain by red coarse sand and granular conglomerate S-10 Cusseta (?) sand :

Sand, coarse, light-red to brown ; few small clay flakes and balls_. $0-4$ Unconformity (?).

Blufftown formation:

Clay, sandy, gray, mottled with red; contains ironstone

Clay, light-gray, mottled with red (probably weathered dark-gray clay)

Ironstone ; contains coarse sand

Clay, buff to light-gray; contains ironstone throughout; grades into unweathered material farther back in hill

Clay, silty, chocolate-brown to dark-gray, laminated; some carbonaceous matter and lignite fragments

\section{CUSSETA SAND}

\section{GENERAI FEATURES}

Name.-In 1909 Veatch (p. 86-89) proposed the formational name Cusseta sand for nonmarine beds of Ripley age between his Renfroes marl and his Blufftown formation. The type locality is in railroad cuts near Cusseta, Chattahoochee County, Ga. Stephenson in 1911 p. 152, 161-163) repeated this description of the Cusseta sand but called the Cusseta the basal member of the Ripley formation underlain by the Tombigbee sand member of the Eutaw formation, thus excluding the Blufftown formation. Stephenson and Monroe (1938, p. 1642, 1649-1650) gave the Cusseta sand formational rank because of a disconformity between it and the underlying Blufftown formation (which name they revived) and because of marked lithologic difference from the overlying Ripley formation. In Alabama the Blufftown, Ripley, and Providence are now considered formations in the Selma group and the Cusseta is there considered a member of the Ripley formation because the boundary with the overlying beds is not distinct. In Georgia, however, the Cusseta is a mappable lithologic unit that can be differentiated from the overlying fossiliferous beds of the Ripley formation. The use of the term Selma group has not been extencled. into Georgia. 
Areal extent.-The Cusseta sand can be traced as a lithologic unit from the Chattahoochee River valley northeastward to the Flint River valley. The contact of the Cusseta sand with the overlying Ripley formation can be traced east of the Flint River to the Ocmulgee River valley, but the base of the Cusseta cannot be so traced. In the Chattahoochee Valley the outcrop belt of the Cusseta sand is 3 miles or more wide and maintains that width northeastward as far as it is identifiable.

Lithologic character.-The Cusseta sand lies unconformably on fine sand and clay of the Blufftown formation. Near the Chattahoochee River the basal part of the Cusseta consists of coarse highly glauconitic sand containing waterworn shells, fragments of lignite, and other detrital materials. In higher parts of the formation the sand contains beds of laminated chocolate-colored marine clay; the sands are coarse, glauconitic, and irregularly and steeply crossbedded. In many places they contain borings of Halymenites major. Down the dip in the deeper creek valleys and in the flood-plain area of the Chattahoochee River, much of the sand is fine, very micaceous, and glauconitic. The upper contact is apparently conformable with the Ripley formation, the base of which is another coarse sand, crossbedded and with borings, that represents the beginning of a new cycle of deposition. This contact is recognized farther east than any other contact in the Cretaceous of Georgia, chiefly because the Ripley maintains its marine characteristics as far east as the Ocmulgee River, whereas the immediately underlying and overlying formations apparently became continental in that direction.

Up the dip the Cusseta is chiefly coarse sand having minor lenses of massive clay that weathers white. It forms the high rolling sandhills around Cusseta, the type area, and to the east where it is a part of the extensive sandhill belt. The basal beds up the dip are coarse sand and gravel without the fossils and other detrital matter found at that position down the dip in the Chattahoochee River valley.

Several miles east of Cusseta the basal contact is somewhat obscure because some of the beds of sand in the upper part of the Blufftown formation are also coarse. Generally, however, the upper Blufftown has dark-gray carbonaceous fissile clay interbedded with the sand, and the Cusseta sand has a coarse granular irregularly bedded conglomerate at its base. By means of these criteria the base of the Cusseta has been traced across the high sandhills of Marion and Taylor Counties. The base of the Cusseta sand has a more northerly strike than does the top of the Tuscaloosa formation from Taylor County eastward, and somewhere east of the Ocmulgee River it may overlap the lower formations at least in part (pl. 3).

Like the underlying formations, the Cusseta sand changes in lithologic character toward the east. In southern Chattahoochee and 
northern Stewart Counties irregular beds of chocolate-colored clay, interbedded with sand that locally contains Halymenites borings and that has little resistance to erosion, are equivalent to the glauconitic sands and thick beds of montmorillonitic clay exposed down the dip in the Chattahoochee River valley. In the north half of Marion County the clay beds are white and kaolinitic, and at least 2 are fairly persistent, 1 near the top of the formation and 1 near the bottom. The coarse sand also contains white kaolinitic clay balls, scattered and in layers, and has conspicuous deltaic crossbedding. In western Taylor County, deep gullies that notch the rim of the high cuesta just east of Mauk expose loose pale Cusseta sand beneath firm dark-red clayey sand of the Ripley. In weathered exposures the Cusseta is a very-pale-reddish-brown sand that contains characteristic white clay balls and thin clay lenses.

Farther east, near the center of Taylor County, the white clay lenses are commercial sources of sedimentary kaolin. The westernmost kaolin mine in Georgia at the time of this survey was in the Cusseta sand, $21 / 2$ miles west of Butler, Taylor County. The minable clay bed varies from 3 to 6 feet in thickness. The clay is pale gray in the mine face, dries to white, and contains some fine to coarse quartz sand. Some of the sand below the minable bed is clayey and carbonaceous and weathers to variegated colors-pale purple and red and very pale gray. Regionally the clay beds are lenticular. Along U. S. Highway 19 south of Butler, 21/2 miles southeast of the mines west of Butler, the clay bed is only 2 feet thick and is too sandy to be commercial.

East of Butler, the Cusseta varies little. It is possibly the same throughout Crawford County, too, but there it has not been separated in the mapping from the underlying Blufftown formation. In central Crawford County, Tertiary strata overlap the higher Cretaceous beds and probably lie on clays and sands of the Cusseta. An excellent exposure of the Tertiary sediments resting on probable Cusseta sand is in lime pits on the southwest slope of Rich Hill, 6 miles east-southeast of Roberta, where about 25 feet of unweathered soft Ocala limestone rests on 4 feet of coarse sand of Tertiary age, and this in turn rests on 11. feet of very-light-gray massive blocky-jointed clay that is believed to be Cusseta. Below the clay is 17 feet of very coarse granular sand containing clay balls throughout. Below that is clayey micaceous laminated very fine sand that may belong to the Blufftown formation. In Bibb County some high hills southwest of Macon are capped with loose sand of the Cusseta, whose age was corroborated by the discovery of a capping on the highest hills of marine red sand, with borings, of Ripley age. East of Macon it was not possible to separate beds of Cusseta age from the overlying strata of Ripley age. 
Thickness.-The Cusseta sand is about 185 feet thick in the Chattahoochee River region. Its thickness cannot be accurately measured farther east but appears to be about the same as far as the Flint River. As the base cannot be recognized east of the Flint River, the thickness in central and eastern Georgia is not known.

\section{IOCAL DETAILS}

Quitman County.-The upper beds of Cusseta sand are found low in the Chattahoochee River valley in the northwest corner of this county. In banks of the river and in tributary ravines about 11/2 miles northeast of the mouth of Cowikee Creek (on the Alabama side) and 0.1 mile below the mouth of Bustahatchee Creek, firm dark-gray micaceous friable clay contains abundant fragile shells of mollusks. In cuts half a mile south of Bustahatchee Creek on the FlorenceGeorgetown road the upper part of the Cusseta is reddish-brown weathered fissile clay. Just south of Bustahatchee Creek in the bed of a small branch beside a county road about three-quarters of a mile southeast of Avreys Store, micaceous fissile dark-gray clay containing thin-shelled mollusks and leaves and fruit of plants is exposed. About 50 feet uphill a coarse sand containing pea-sized gravel lies on clayey fine sand, forming the Cusseta-Ripley contact.

Stewar' County.-The upper beds of the Cusseta sand are exposed at the foot of most of the high uplands in western Stewart County. At Coffinton, an abandoned post office in the southwest corner of the county, the Cusseta sand consists of dark-red-weathering greenish-gray clayey sands that contain glauconite and fine mica. Coarse sand derived from the overlying Ripley formation covers the exposures.

In branches in the valley of Roods Creek, about 4 miles directly east of the Chattahoochee River and along a secondary road, upper beds of the Cusseta appear below a long section of Providence sand and Ripley formation. Here the Cusseta consists of clay, containing silt and fine sand, that weathers dark red and grades downward into fine sand containing glauconite, coarse mica, and clay as much as 65 feet above the bed of Roods Creek. Throughout Stewart County to the northeast the clays of the uppermost Cusseta grade downward into glauconitic sands, which, in turn, grade downward into coarse crossbedded sands.

The basal bed of the Cusseta at several localities along the Chattahoochee River (Stephenson, 1911, p. 155-160; Cooke, 1943, p. 24-26) has been described as a shell marl containing abundant waterworn shells, teeth and bones, fragments of silicified or lignitized wood, and other coarse debris. Such is the material at Woolridge Landing on the Alabama side, 1 mile above the mouth of Roods Creek and at Lower Roods Bend, just below the mouth of Roods Creek. 
A similar exposure was found also in the left bank of the river at the old Thompsons Landing site about 2 miles above the mouth of Roods Creek.

Very glauconitic dark-gray clayey sand in the banks of Roods Creek near the river is evidently in the lower part of the Cusseta, but the basal contact was not found in the creek.

The upstream part of the bluff at Florence, Ga., considered previously to be Cusseta sand (Cooke, 1943, p. 24-25), was reexamined during this survey. Of interest there are a number of molds of ammonites and nacreous fragments of ammonite shells and of Inoceramus sp., in addition to the fossils described by Stephenson (1911, p. 156). One compressed lignite $\log$ about 15 inches wide, amber nodules, and a specimen of Hamuitus sp. about 4 inches long were also found. Most of these were found near the base of a 30 -foot section of dark-gray silty micaceous clay that is especially fossiliferous in the basal 6 inches. All the fossils are fragile. Near the base is also a layer of septarian nodules, calcareous and hard, that contain prismatic calcite internally and are as much as 3 feet long and 1 foot thick but average about, 1 foot long and 6 inches thick. The contact with the underlying material is sharp but appears to be conformable and is at an altitude of about 180 feet above sea level. Beneath this is 4 feet of glauconitic micaceous fine sand, containing thin carbonaceous clay layers, that becomes more clayey toward the base of the exposure. If the upper bed of this section of the river bluff is Cusseta, it is quite different lithologically from most exposures seen, as at most places the basal beds are coarse sand. The lithology, therefore, resembles more the Blufftown than the Cusseta. All the beds dip strongly here, about $2^{\circ}$ to $3^{\circ}$ to the south. Unless these steep dips were reversed or flattened in a short distance downstream, the beds cropping out here would be carried too far below river level to be exposed again at Woolridge Landing and other places nearly 4 miles downstream. No reversal of dip was observed at any place downstream. Thus, the beds at Florence are now considered by the author to be of Blufftown age, considerably below the contact with the Cusseta.

A definite contact between the Cusseta sand and Blufftown formation is 2.6 miles east-northeast of Florence, less than a mile up the dip from Florence. Here, in shallow gullies north of the road and at an average altitude of 276 feet, glauconitic coarse to fine sand of the Cusseta contains borings, clay fillings of fossils; and some indistinct fossil impressions. Underlying this is very fine nonglauconitic white crossbedded sand of the Blufftown, containing thin lenses of bentonitic clay and many borings of Halymenites major. In gullies farther west more than 30 feet of the fine sand of the Blufftown is exposed. The Blufftown contains, in addition, half-inch lenses of 
bentonite and some thicker beds of clay. The thicker beds of clay contain abundant borings of H. major. Northeast of this locality the Cusseta is exposed in the valley sides of Hannahatchee Creek. As the dip of the formation gradually rises to the north, the land of its outcrop becomes more rolling, and the basal beds of the formation cap high hills near Cusseta, Chattahoochee County, the type area of the formation.

Chattahoochee County.-The exposures near Cusseta are typical of the updip facies of the Cusseta sand that caps the high hills in the southwestern part of the county. Sands of updip facies form the broad irregular band of the main outcrop in the eastern part of the county.

In a railroad cut three-fourths of a mile west of Cusseta is exposed an irregular contact of coarse gritty ferruginous arkosic micaceous sand lying on fine crossbedded micaceous purple to yellow-stained sand, containing a small lens of coarse sand near the west end of the cut. The overlying coarse sand is derived from the Cusseta sand but obviously has been reworked by colluvial processes which have cut into the fine sand of the Blufftown formation. About 25 feet of this fine sand is exposed; all of it has been cut out in places and replaced by coarse sand, probably by surficial processes. The fine sand lies on a bed of dark-gray carbonaceous fissile clay containing silt, fine sand, and especially toward its top, abundant molds of small pelecypods. About 8 feet of the clay is exposed.

In a cut on U. S. Highway 27, 0.2 mile south of the intersection with U. S. Highway 280 in Cusseta (in front of the courthouse), was an excellent exposure of the contact of the Cusseta sand and the Blufftown formation (fig. 6). This should be considered as the part of the type section of the Cusseta sand that shows its basal contact, for it shows the relationship undisturbed by surficial influences and was better exposed at the time of this survey than any other exposure of the contact seen near Cusseta.

S'ection in Cusseta on U. S. Highuay 27, 0.2 mile south of intersection with U. S. Highway 280

Cusseta sand :

Feet

Sand, coarse; a few beds of finer sand contain borings and clay laminae; covered with 3 feet of residual sand. Basal contact sharp and irregular at an altitude of about 470 feet. From top of cut.

Unconformity.

Blufftown formation:

Sand, fine, yellow

Clay, gray, fissile, carbonaceous; contains very fine sand. Grades into bed below

Sand, very fine, slightly clayey, gray; contains borings and scattered coarse grains

Sand, fine, white; a few borings at top. Exposed to bottom of gully beside road 
Downhill from this exposure, below a covered interval of about 50 feet, about 15 feet of clayey gray sand, with borings, grades downward into dark carbonaceous sandy clay. In other cuts downhill an additional 35 feet or more of fairly micaceous carbonaceous very fine sand is exposed. In this area most of the upper 100 feet of the Blufftown formation, therefore, is sand having a minor amount of clay.

The contact of the Cusseta sand with the overlying Ripley formation is well exposed in gullied road ditches $4 \frac{1}{2}$ miles southeast of

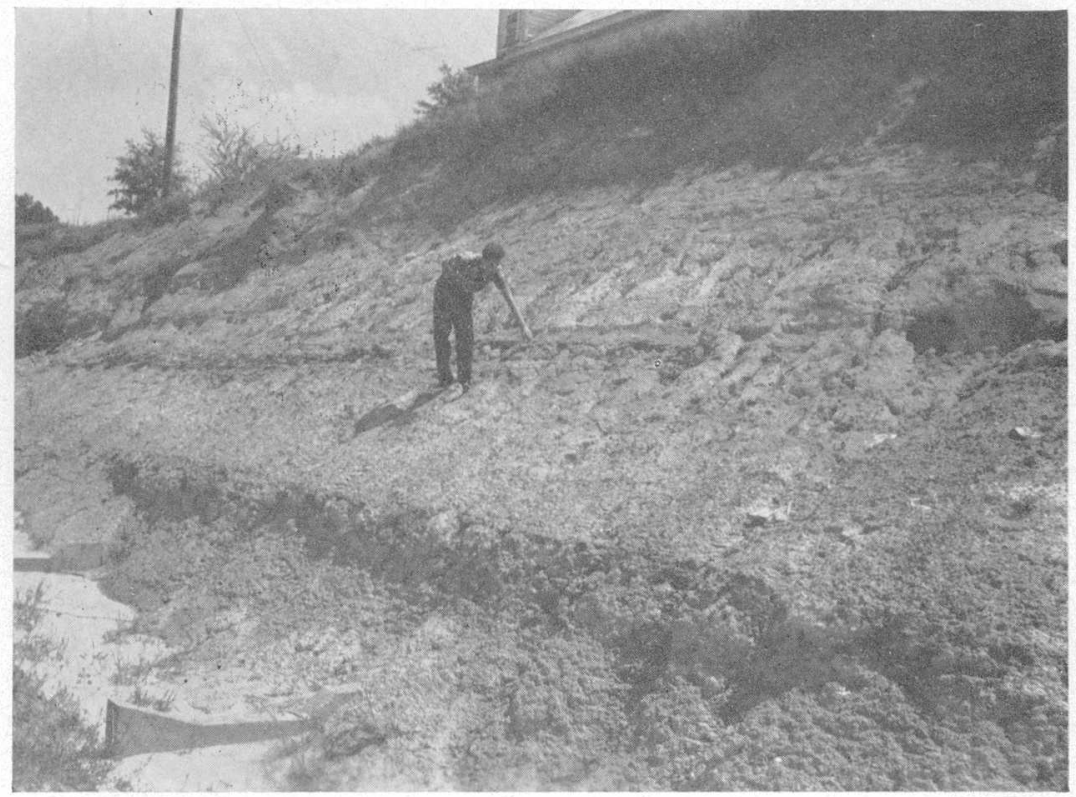

FIgURE 6. - The contact between the Cusseta and the Blufftown at the type locality of the Cusseta sand. The man is pointing to the contact between coarse sand of the Cusseta and fine sand of the Blufftown. Two feet below the contact is the top of a 4 -foot bed of carbonaceous sandy clay, which grades into fine sand at the bottom of the cut. East side of cut, U. S. Highway 27, 1,000 feet south of the courthouse at Cusseta, Chattahoochee County.

Cusseta on a northward-trending road, about 50 yards south of U. S. Highway 280. Here, massive firm arkosic sand, containing fine gravel and borings, of the Ripley lies at an altitude of about 485 feet on loose coarse sand containing fine gravel and beds of laminated chocolate-brown clay.

A longer section is exposed 3.4 airline miles southeast of the courthouse in Cusseta on a county road trending generally southeast, about half a mile west of U. S. Highway 280. On that hill about 15 feet of greenish-gray marl of the Ripley formation grades downward into clayey sand whose base is coarse arkosic red sand; this lies abruptly on laminated clay and fine sand of the Cusseta at an altitude of about 
500 feet. Farther downhill, gullies expose 30 feet of the Cusseta which consists of coarse loose easily erodible sand containing lenses of laminated chocolate-brown clay.

The basal Cusseta sand is well exposed in a cut on State Highway 26, 31/2 miles east of Cusseta, just east of a road that intersects from the southeast (fig. 7). Here, loose crossbedded sand with fine gravel at the base lies irregularly on very micaceous fine sand at an altitude of about 460 feet. North of this highway, in the east end of Fort

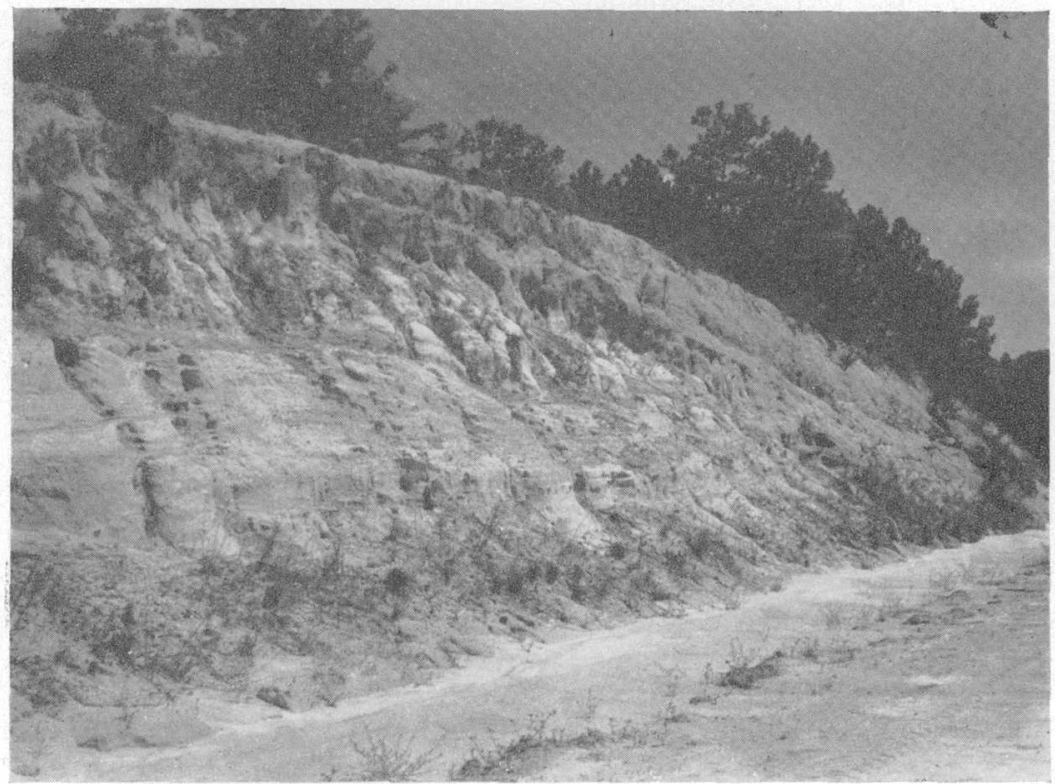

Figure 7.-A typical exposure of basal Cusseta sand east of the type locality. The material ranges from very coarse sand to fine conglomerate and is crossbedded and slightly ferruginous. Far end of cut is covered with colluvial soil. North side of State Highway 26, 31/2 miles east of Cusseta, Chattahoochee County.

Benning Military Reservation, high hills are capped with coarse sand and conglomeratic ironstone.

Marion County.-Throughout the north half of Marion County loose sand of the Cusseta sand is exposed generally downhill from the higher parts of the sandhill plateau, which is capped by resistant red clayey sand of the Ripley formation. This difference between Cusseta and Ripley is especially conspicuous down the dip where the Cusseta occupies only the lower parts of the slopes, as in headwater valleys of Kinchafoonee Creek along State highway 137, northeast of Buena Vista toward Tazewell.

A typical Ripley and Cusseta contact is 1 mile south-southwest of Blueville Pond, 4 miles northwest of Tazewell, where the following section is exposed: 
Ripley formation :

Sand, fine, red, ferruginous; grades downward in the lower 1.5 inches

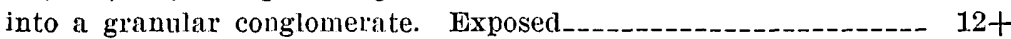
Cusseta sand:

Clay, purple and white, lenticular; weathers to lavender. Ironstone at base

Sand, coarse, crossbedded ; some faint borings

15

The updip outcrop of the main body of the Cusseta sand forms rolling hills covered with deep sandy soil and has a local relief of 200 feet or more. The smooth hills are now covered mostly with blackjack oak, although they once supported a magnificent stand of longleaf or yellow pine. A scattered stand of these valuable trees still remains, and some young trees grow above the scrub oak. On cleared areas and especially along roads the loose soil washes extremely easily and most roads have to be graded constantly to remove the sand. To make the roads more permanently usable, a surfacing of red clayey soil from the outliers of the Ripley formation to the south is spread over them; other wise, most of the lower places in the roads soon become impassable for the average car.

In this county, as in Taylor County, weathered residual sand of the Cusseta, generally colluvially reworked, so merges with the Blufftown formation that little distinction can be made between the two formations, and the boundary is indistinct. Generally this far east the Blufftown contains clay beds thick enough to produce a low bench below the higher hills, which are capped with coarse sand from the Cusseta, and the boundary between the two has been projected for some miles on this basis. However, several good exposures of the contact to the east in Taylor County give further control in that direction.

Taylor County.-The Cusseta sand crops out on the flanks of the high plateau formed on the Ripley formation across the central part of the county. From a few miles west of Butler to Reynolds it forms a high rolling surface only slightly lower than the plateau to the south. which is capped by the Ripley. The Cusseta in this area consists generally of very pale sand weathering reddish brown and containing beds, lenses, and balls of white clay. Half a mile east of the railroad station at Mauk (altitude 7.80 feet), about 12 feet of dark reddishbrown clayey sand of the Ripley formation overlies about 25 feet or more of loose coarse sand containing thin beds and rounded balls of white clay (fig. 8). The Cusseta sand beneath the residuum of the marine Ripley is so easily removed by gullying that the upland rim is notched by gullies at almost every place where water is concentrated into shallow drainage lines. The material of the Ripley is more resistant and forms the sides and heads of the gullies, whereas that of the Cusseta washes downstream and forms long sand trains in the valley bottoms. 
Two and one-half miles east of Mauk, on the farm of David Harbuck, in a gully in pinewoods a quarter of a mile east of a north-trending road, a lens of sedimentary kaolin 23 feet thick is overlain by clayey sand and silt that is easily removed by gullying. The clay is practically free of sand but contains numerous hollow purple and dark-red ferruginous concretions, some with double shells, about the

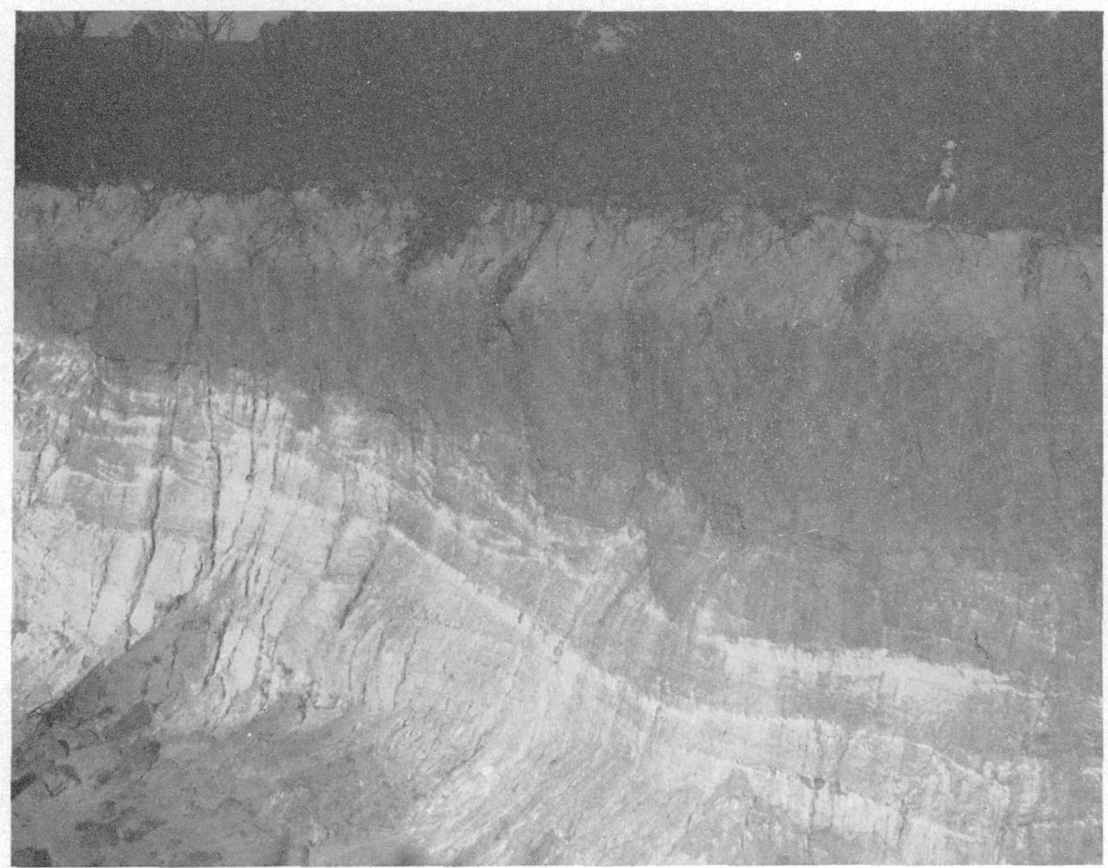

Figure 8.-Contact of the Cusseta sand and the Ripley formation. The darker stratum at the top of the gully is red clayey coarse sand of the Ripley formation, which overlies pale sands and thin beds of white clay of the Cusseta sand. Half a mile east of Mauk, Taylor County.

shape and size of hens' eggs. Compound and irregular concretions are also common. The clay itself is massive, jointed, stained very pale purple or pink, and laminated with thin bands of darker purple that give a pictorial effect.

In the southwestern part of the county in inliers of the Cusseta sand, similar beds of clay are enclosed by loose sand, as at the following site:

Section in abandoned bed of State Highway 13\%, 21/2 miles southwest of Charing

Soil and colluvial sand, mostly from Ripley formation:

Sand. From top of hill, about

Cusseta sand:

Clay, light lavender, massive, blocky, highly jointed, fairly brittle but firm; a few ferruginous spots or concretions on unweathered outcrop

Sand, clayey, pale 
Sedimentary kaolin is mined by the Interstate Mining Corp. from a lenticular bed in the Cusseta sand $21 / 2$ to 3 miles west-southwest of Butler on State Highway 137. This is the westernmost point at which kaolin was produced from the Cretaceous of the State at the time of the survey. The geology of the area and of the mines, which were formerly owned by Golding Sons Co., Trenton, N. J., was described by Richard W. Smith (1929, p. 66-67), but at that time the beds were considered to be of Tuscaloosa age. At the time of this survey, one pit south of Highway 137 was being worked. In it about 3 to 6 feet of clay was of minable quality although some of it was slightly sandy, the sand being coarse to fine subangular quartz grains. The clay is massive, brittle, very light gray, bleaches to white upon drying, and has a conchoidal fracture. It is overlain by several feet of fine to coarse sand whose thickness varies with the topography and is underlain by clay, too sandy to be commercial, that in old workings appears to be carbonaceous and weathers to gray mottled with purple.

These same beds probably are exposed in cuts on U. S. Highway 19, 2.3 miles south of Butler, where the clay is 8 feet thick and covered with gray colluvial sand. Near the top the clay is massive, very pure, and has a conchoidal fracture, but toward the bottom it is sandy. The color ranges from very pale orange to grayish orange pink when moist in the bank, but it is generally very pale orange when dry. About 20 feet downhill is a cut in which a maximum of 3 feet of crossbedded coarse sand irregularly overlies 8 feet of white to pink clay. The clay bed contains some clay-ball lenses as much as 8 inches thick and in places it is interbedded with medium to coarse sand.

About 3 feet of a clay bed is exposed 7.2 miles south of the Butler railroad station on U. S. Highway 19 behind Silas Harris' store at Upton's Mill on Whitewater Creek, and in a gully 300 yards west of the store. Here the clay is massive, fairly pure, weathers to pale red and is overlain by very coarse sand and ironstone.

A quarter of a mile east of Pebble Station on the Central of Georgia Railway, $31 / 2$ miles east of Butler, 10 feet of coarse light-reddish to yellowish-brown sand is broadly crossbedded, semi-indurated by exposure, and contains some layers of loose sand; it overlies sharply and irregularly 6 feet of white silty clay that is slightly mottled with light reddish purple and pink. Slightly farther east in the railroad cut, and downhill in the cut of State Highway 96, coarse light-reddishbrown sand overlies silty white clay containing ironstone. The clay is reddish brown where it is weathered and affected by soil-forming processes near the end of the cut.

Excellent exposures of crossbedded pale-reddish-brown coarse sand of the Cusseta containing white clay balls are found in road cuts and 
gullies south of State Highway 96, three-quarters of a mile west of Leona or 3 miles west of Reynolds.

Crawford County.-The lower part of the Cusseta sand cannot be distinguished from the sand of the Blufftown formation east of the Flint River. Some exposures of the contact between the Ripley and Cusseta, however, and of the beds underlying this contect, were found east of the Flint River. These beds are so similar to the Cusseta west of the Flint River that the author believes them to be definitely of that formation. They are especially well exposed in the southern part of the county north of the Central of Georgia Railway and north of Zenith on the Southern Railway. An excellent and typical exposure is 2 miles southwest of Zenith on an access road just west of the main county road from Zenith to Nakomis. Dark-reddish-brown clayey sand of the Tertiary rests unconformably on Ripley, which consists of lighter red slightly clayey very fine sand, with borings, grading downhill into a granular conglomerate; this lies on light red loose granular very coarse sand of the Cusseta. About 11/2 miles north of Zenith, just west of the Southern Railway, is an abandoned sandpit mostly in the Cusseta sand. It shows about 40 feet of Cusseta consisting of cross-bedded fine gravel and sand containing some mottled clay near the top and a lens of white silty clay grading downward into clayey sand and then into fine sand at the bottom of the pit; at one end of the pit is a thin wedge of partially reworked red sand of the Ripley formation. The whole section is covered by 20 feet, more or less, of colluvially reworked surface sand or soil.

About 21/2 miles north of Zenith on the north side of the Southern Railway, pits of the Atlanta Sand and Supply Co. are in the Cusseta sand. The pits cover about 50 to 60 acres and have a working bank 50 to 75 feet high. A few clay lenses are found in the sand, one measuring 14 feet in thickness and several acres in extent. As the purity of the sand is the principal quality desired in the product, these beds of clay are unwanted and frequently limit the workings. Some are left standing as pillars or "mesas" in the pits.

Bibb County. - Coarse sand of probable Cusseta age, some of it containing fine gravel and overlain by white clay, is exposed on the high ridge between Tobesofkee Creek to the northeast and Echeconnee Creek along the southwest border of the county, beneath outliers of definite Ripley sand containing borings of Halymenites major. The ridge is covered for the most part with a deep residual sand typical of Cusseta sand farther west.

\section{RIPLEY FORMATION}

GENERAL FEATURES

Name.-E. W. Hilgard (1860, p. 3, 83-95) first used the name Ripley to designate the strata in Mississippi between his Rotten Limestone 
(Selma chalk) and his overlying Northern Lignite of Tertiary age (Porters Creek clay). His type locality was at the town of Ripley, Tippah County. Harris (1896, p. 22-25) showed that Hilgard's Ripley included at its top a few feet of limestone that properly should be included in the base of the Midway group of Paleocene age. About 40 feet of sand and clay immediately below the Midway were informally called Owl Creek marl by Hilgard and included in his Ripley group. Stephenson and Monroe (1937, p. 806-809) showed that Hilgard's Owl. Creek is separated from the beds below by an unconformity; they treated it as a formation and showed that it grades southward into the Prairie Bluff chalk. The beds now exposed on the eastern flank of Pontotoc Ridge, several miles east of Ripley, are typical of the Ripley. The name Ripley now includes the part of Hilgard's Ripley group that lies above the Demopolis chalk and below the Owl Creek formation and its equivalent, the Prairie Bluff chalk.

The name Ripley has been used to include correlative deposits in Temmessee, Kentucky, Illinois, and Missouri, and eastward into Alabama and Georgia.

In Alabama the name is used in western Sumter County for chalky sand and clay beds essentially contemporaneous and continuous with the Ripley of Mississippi. Farther east in Alabama successively lower parts of the Demopolis chalk grade laterally into a sand and clay facies that is designated Ripley. In eastern Alabama the Ripley includes all strata between the underlying Blufftown formation and the overlying Prairie Bluff chalk or its correlative, the Providence sand. Coarse sandy beds at the base of the Ripley in eastern Alabama, designated the Cusseta sand member, represent the western feather-edge of the Cusseta sand of Georgia.

In Georgia the name Ripley is applied to the sand and sandy clay that contain fossils in upland areas. The strata, originally described by Veatch (1909, p. 86-89) as Renfroes marl, lie between the Cusseta sand and the Providence sand. Faunally, the Ripley includes the part of the Exogyra costata zone below the Providence sand and possibly the uppermost part of the $E$. ponderosa zone.

Areal extent.-The Ripley formation crops out in a narrow belt from the Chattahoochee River northeastward to the Ocmulgee River. Locally between the Flint and Ocmulgee Rivers it is concealed by overlapping sand of Tertiary age. A few miles east of the Ocmulgee River in Twiggs County, red-weathering sand containing Halymenites borings was found by Stephenson and Thompson (1943, unpublished report) at approximately the stratigraphic position of the Ripley. A A short distance east of that point the Ripley beds become indistinguishable from the other Cretaceous formations.

Lithologic character.--Throughout Quitman and Stewart Counties a little over 100 feet of fine marine sand that is generally massive. 
clayey, calcareous, and highly fossiliferous, and that closely resembles the Ripley formation of Alabama, lies between the Cusseta sand and the Providence sand. The calcareous clays or marls, especially, abound in thick-shelled fossils that are more resistant to weathering than those in noncalcareous beds.

Lying sharply, but perhaps conformably, on the underlying Cusseta sand, the Ripley is traceable eastward to the Ocmulgee River, in spite of facies changes. West of Flint River it is chiefly a clayey fine to coarse sand, producing red clayey soils that are firm and resistant to gullying. Eastward from Marion County the basal beds of this unit consist of clayey coarse sand that forms the dip slope of a high cuesta that extends northeastward through Taylor County. These basal beds of the Ripley underlie the high gently sloping plateau in the vicinity of Mauk and give rise to excellent agricultural land, in contrast to the rolling hills of infertile, deep sandy soil produced by the Cusseta sand. The highest part of the upland near Mauk averages 800 feet above sea level, whereas the nearest stream bottoms to the north are 300 to 400 feet lower.

A nearly flat upland of similarly fertile red soil just south of Butler is at an altitude of 650 feet or less and down the dip in relation to the plateau at Mauk. Because of the soil color this upland has been misinterpreted by earlier workers as being capped by an outlier of 'Tertiary beds. The structural maps (pl. 3) show that the presence of Tertiary residuum here is unlikely, although the extreme degree of weathering of the rocks in this region makes definite determination on the basis of lithology difficult.

Near the top of the formation a distinctive bed of highly fossiliferous and calcareous very fine sand and clay, or marl, crops out over a wide area in western Georgia. It can be well seen below the Providence sand in the bottoms of the Providence Canyons and other deep gullies of Quitman and Stewart Counties and on the high north-facing cuesta that trends northeastward through Stewart County. In most places only prints of shells remain, but a number of unweathered exposures contain abundant shells of species typical of the Ripley formation of Tennessee, Mississippi, and Alabama. Fossil prints have been found by Zapp (Cooke, 1943, p. 34) as far east as the east bank of the Flint River in northern Macon County. No fossils except borings of Halymenites major have been found east of that point.

Marine beds of the Ripley are partially overlapped by Tertiary rocks in eastern Crawford County. In southern Crawford County 60 feet or more of the Ripley crops out beneath the overlapping 'Tertiary strata. Stephenson (1911, p. 167) has illustrated and described in detail the fine sand of the exposed Ripley in the extensive cuts near Zenith and has shown that in northeastern Peach County 
the Ripley has lenses of clay containing fossilized leaves. The carbonaceous beds are highly fissile and are clay containing very fine sand.

In northern Peach County inliers show the Ripley formation to be a red-weathering clayey very coarse sand that contains abundant Halymenites borings. Except for these inliers and exposures on the southern valley wall of Echeconnee Creek, the Ripley is generally concealed by the overlapping Tertiary strata in eastern Peich and in Houston Counties. In southern Bibb County an outlier nearly 3 miles long on the crest of a high ridge consists of red fine sand containing clay films and Halymenites borings; this grades downward into very coarse sand, with borings, which is exposed in cuts along an old railroad right-of-way, 1 to 2 miles west of Skipperton and 8 miles southwest of Macon.

Near the Ocmulgee River in Twiggs County, Stephenson and Thompson (1943, unpublished report) found Halymenites borings in sand down the dip from some of the clay-producing areas of that county. The exact age of this material and of other material containing questionable borings found by the writer farther east in Twiggs County is not definitely known. However, because of their general stratigraphic position, resemblance to the Ripley formation west of the Ocmulgee River, and the presence of borings, the materials are believed to be of that formation.

Thickness.-The Ripley formation is about 135 feet thick in the Chattahoochee River valley, but farther east its full thickness is not known because of the overlap of Tertiary beds. A maximum of about 50 feet of the basal coarse sand, with borings, is exposed just west of the Ocmulgee River. About 120 feet of fine marine sand, lying below kaolinitic sand in the Tricon Minerals, Inc., H. B. Gilbert well no. 1 in Houston County, about 4 miles south of Perry (fig. 17), is believed to belong to this formation; however, the basal coarse sands, if present in the subsurface, could not be distinguished with certainty from the Cusseta sand.

\section{LOCAL DETAILS}

Quitman County.-The Ripley formation occupies the sides and bottom of the Chattahoochee River valley for most of the distance along the west boundary of the county. One of the best exposures of the upper part of the Ripley and its contact with the overlying Providence sand was seen in the west bank of the Chattahoochee River opposite Georgetown, Ga., in the city of Eufaula, Ala. The contact between the Providence and the Ripley was found at the level of the bridge between the two towns, about 500 feet downstream from the bridge. In this bank, the Perote member at the base of the Providence sand is gray very micaceous silty and clayey very fine sand containing 
numerous weathered thin-shelled mollusks and grades downward into a 3-foot layer of calcareous clayey sandstone containing abundant lignite fragments and shiny black phosphatic grains. This basal bed of the Providence sand overlies, with distinctly contrasting lithologic character, dark-gray clayey fine sand of the Ripley formation. The sand of the Ripley formation contains some mica but not nearly so much as the Providence sand above. In the bottom of a ravine are loose shells of Exogyra costata and large shells of Gryphaea convexa (or large convex specimens of $G$. mutabilis?) that have probably been washed out from the Providence sand. Shells of these species were not found in the upper beds of the Ripley here. The silvery sheen produced by the high mica content of the Providence sand, its softer feel, and its more highly layered character tend to distinguish it from the Ripley in this area.

Another exposure of the same contact, just south of Tolannee Creek along a county road about a mile southeast of the courthouse at Georgetown, is probably the Mercers Mill Creek locality of Stephenson (1911, p. 181-182). Here, dark-gray very fossiliferous and micaceous layered sand of the Perote member of the Providence sand, the beds of which have previously been assigned to the Ripley (Cooke, 1943 , p. 32), sharply overlies massive dark-gray clayey sand of the Ripley formation, the contact being about 20 feet above the valley bottom. In the bed and banks of the creek is a good exposure of the gray clayey sand of the Ripley. The contact between the Providence and Ripley passes beneath the Chattahoochee River just below the mouth of Cool Creek on the Georgia side and Barbour Creek on the Alabama side, about 51/4 miles south-southwest of Georgetown.

The Providence and Ripley contact is exposed on the FlorenceGeorgetown road on a long hill south of Soapstone Creek about 5 miles northeast of Georgetown, about 100 feet below the top of the hill and about 110 feet above the bottom of the valley. The lower part of the Providence consists of fine sand, at the base of which is a 10-foot bed of coarse sand containing fine gravel and some lenses of fine sand. It lies on very micaceous fine sand of the Ripley formation which grades downward into' slightly clayey and micaceous uniformly massive sand. In the lower 40 feet of the hill are unweathered beds of clayey dark-gray sand. This contact is about 100 feet higher than the one just below the Eufaula-Georgetown bridge and is about 4 miles up the dip from it.

Both bounding contacts of the Ripley formation are exposed along a road trending southeastward on a long hill south of Bustahatchee Creek in the northwestern part of the county, though the intervening beds are not continuously exposed. Here gravelly sand of the Ripley rests on clayey fine sand of the topmost Cusseta that grades downward into a dark-gray fissile micaceous fossiliferous clay. About 135 feet 
uphill and half a mile southeast, the basal fine gravel of the Providence sand rests on fine sand of the Ripley.

Clayey fine sand of the upper part of the Ripley formation is exposed below a complete section of Providence sand in the bottom of large gullies in the northern part of the county. Perhaps the largest and deepest gullies seen in the Southeastern States are on the farms of F. J. Graddy and W. E. Graddy, about half a mile west of State Highway 27 at Rocky Mount Church, immediately north of an eastward-trending road. The large well-exposed inlier of the Ripley formation in the valley of Hodchodkee Creek in Stewart County also extends several miles southward into the northeastern part of this county.

Stewart County.-A complete section of Ripley formation is exposed on an unimproved road into Roods Creek valley, 3 miles west of Oak Grove Church and School and 4 miles northwest of Sanford on State Highway 26 (Lumpkin-Georgetown road). 'The approximate section is as follows:

Section on unimproved road, beginning 1 mile north, of 'l'empleton, cemetery (BM 529) and leading into the valley of Roods Creck, \& miles nor thuest of sanford

Providence sand :

Upper member :

peet

Sand, coarse; grades downward into fine gravel and sand and ferruginous conglomerate. Exposed_______. $15+$

Perote member:

Sand, fine, very micaceous, and some clay; fine gravel and ferruginous conglomerate at base

Ripley formation:

Sand, fine, medium-gray, micaceous; wenthers yellowish gray_-__ 1.12 Cusseta sand :

Clay, silty, and fine sand, brown; weathers dark red ; grades downward into clayey fine sand with glauconite and coarse mica. Exposed

The Ripley formation is exposed on the sides of the high cuestin through Stewart County that is capped with residuum of the Claytoin formation (Tertiary) and with the Providence sand. This ridge is the extension into Georgia of the Troy cuesta of Alabama, described by Monroe (1941, p. 42-43). Down the dip to the south the Ripley is exposed chiefly in the bottoms of valleys and in deep gullies formed in recent years. Material of the Ripley is firm and resistant to the extremely active erosion that has produced the gullies in the Providence sand. Because it is clayey and more impervious than the porous sand of the Providence, springs issue where the upper surface of the Ripley intersects the ground surface. The relatively slow but constant erosion by seepage from springs at the base of the loose Providence sand and near the base of relatively steep slopes is certainly one of the factors that produced the spectacular gullies of the Providence 
Canyons type. Only at a few places, where an unusual amount of surface water had been directed into gully heads, was the erosion by scour and plunge or overfalls found to be the chief agent of the erosion of these gullies. The gullies have a very active early period of growth, but when their heads approach the divide, erosion is slow. Further growth of the gullies keeps pace with the slow erosion of the gully bottoms by a fairly constant flow of water issuing from springs on top of the Ripley formation. In the meantime, trees gain a foothold in the gully bottoms and, because of a good supply of moisture, form a luxuriant growth. The older gullies are, therefore, almost hidden by this new growth at a lower level.

The best exposures of the calcareous and fossiliferous sands and clays of the Ripley formation in Georgia are along the steep frontal. slopes of the cuesta capped by the Clayton formation and the Providence sand. On a county road trending generally north-northeast, $51 / 2$ miles northwest of Lumpkin, beneath a complete section of Providence sand is fine clayey sand and calcareous clay, which is the fossiliferous marly phase of the Ripley. The larger part of a 150 foot section of the Ripley is exposed. Buff-colored marl near the base of the Ripley formation contains coarse sand grains and abundant shells of Exogyra cancellata, Ostrea mesenterica (some shells almost like O. falcata), O. plumosa, Anomia argentaria, and many other mollusks.

Banks of a cut on U. S. Highway 27, 3.7 miles north of Lumpkin, afford an excellent place to see the typical Ripley lithology of western (reorgia and to collect typical Ripley fossils (fig. 9). The following is a generalized section of the strata exposed there and a tentative identification of some of the fossils:

Section on U. S. Highway $2 \pi, 3.7$ miles north of Lumplin, in cuts on a long northfacing hillside

Providence sand :

Feet

1. Sand, coarse, crossbedded; weathers light red; contains borings of Halymenites major and has irregular undulating base. From top of hill, about_............

Unconformity.

Ripley formation:

2. Sand, very fine, very-light red, very micaceous, laminated; weathered at top; grades into bed below. About._........-

3. Sand, marly (calcareous clay), very fine, dark-gray very fossiliferous; calcareous ledges especially fossilferous._-_-_-_-_-_-_- $60+$

Most abundant fossils found in bed 3 are Exogyra costata, Ostrea subspatulata, and Anomia argentaria. Other fossils also in abundance, tentatively identified, are Anomia sp., A. cf. A. tellinoides, Cardium sp., Arca sp., Venus sp., Ostrea plumosa, O. falcata, $O$. mesenterica, $O$. cf. $O$. tecticosta (with rounded longitudinal ridge), 
Pholadomya sp. (large), Paranomia scabra, Gryphaea mutabilis, Turritella sp., and T. trilira, and other mollusks. One layer in bed 3, several inches thick, contains very large specimens of Exogyra costata and Ostrea subspatulata, and smaller ones of Gryphaea mu-

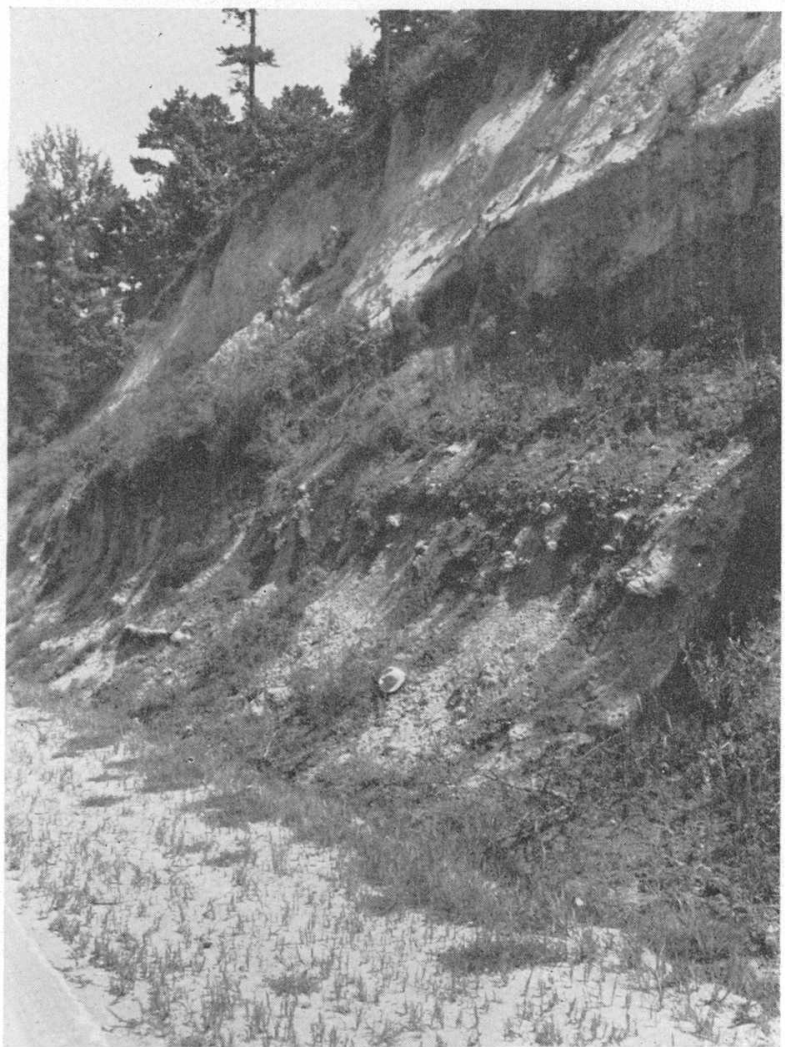

Figure 9.-Fossiliferous dark-gray clayey sand of the Ripley formation. Cut on U. S. Highway 27, 3.7 miles north of Lumpkin, Stewart County.

tabilis and Anomia sp.; most of the others are below this layer.

In bed 3, E. H. Rainwater (Herrick and LaMoreaux, 1944, p. 5859) found the following Foraminifera:

Foraminifera from Ripley formation 3.7 miles north of Lumpkin, Stewart County, Ga.

Fiossil

Frequency

Anomalina pinguis Jennings Common.

Bulimina cf. B. quadrata Plummer

Do.

Cibicides harperi (Sandidge)

Do.

Dentalina alternata (Jones)

Rare.

basiplanata Cushman

Do.

basitorta Cushman

Do.

megalopolitana Reuss

Do.

pauperata D'Orbigny. Common. 
Foraminifera from Rysley formation 3.7 miles north of Lumpkin, Stewart

Fossil County, Ga.-Continued

Frondicularia sp.

Frequency

Gaudryina rudita Sandidge. Common.

Globigerina cretacea D'Orbigny.

Do.

Globigerinella aspera (Ehrenberg)

Do.

Globotruncana cretacea Cushman.

Do.

Globulina gidda D'Orbigny

Heterostomella cf. $H$. americana Cushman

Do.

Jagena globosa (Montague)

Rare.

Loxostoma plaitum (Carsey)

Do.

Marginulina texasensis Cushman

Do.

Nodosaria affinis Reuss

Do.

obscura Reuss

Abundant.

Pullenia americana Cushman. Do.

coryelli White

Rare.

Robulus cf. R. spisso-costatus Cushman

Do.

Do.

Vaginulina cf. V. suturalis Cushman.

Do.

webbervillensis Carsey.

Do.

On a similar north-facing hillside on the road from Pleasant Valley School to Renfroe, about 6 miles northeast of Lumpkin. fine gravelly sand of the Providence overlies, at an elevation of 467 feet (by altimeter), fine sand of the Ripley formation containing very fossiliferous ironstone. The fossils are preserved chiefly as molds and include the following species: I'rigonia sp., Turritella sp., Gyrodes sp., Cardium sp., and other mollusks, and Baculites sp.

One mile north of this locality, on a nose between tributaries of Camp Branch, clayey fine sand of the Ripley overlies hackly micaceous brittle silty gray to dark-gray clay that grades downward into 15 feet of gray hackly silty fine sand. On the basis of the probable thickness of the Ripley, this is very near the base of that formation. A smooth round cobble of milky quartz 5 inches long and 3 inches in diameter was found in a fine-sand matrix about 10 feet above the base of the exposure.

Two miles farther north, in a cut on the same county road, $41 / 2$ miles southwest of Renfroe, about 20 feet of resistant gray clayey coarse sand of the Ripley formation overlies very coarse loose sand of the Cusseta that is interbedded with irregular beds of hackly brittle clay.

Chattahoochee County.-The Ripley formation forms a rolling country of about 150-foot relief in the southeast corner of the county. Some of the higher hills are capped with Providence sand, below which are complete sections of the Ripley. The best exposures of the Ripley found in the county are on the long slope of the hill south of Little Hichitee Creek, along U.' S. Highway 280, north of Renfroe on the Stewart-Chattahoochee County line. In cuts on the county road a quarter of a mile east of the highway in Renfroe, basal beds of the Providence sand are found. Here, coarse sand, with borings, 
of the upper member of the Providence overlies a few feet of clayey fine sand, with borings, of the Perote member. In cuts at the top of the hill on the highway, the basal beds of the Perote member of the Providence sand, consisting of coarse to fine sand, with borings, that weathers light red, overlies gray clayey marl of the Ripley formation. Downhill and a quarter of a mile north of the railroad station at Renfroe, Herrick and LaMoreaux (1944, p. 55) have recorded the following section:

Section one-fourth mile north of Renfroe Station, in cuts on U. S. Highway 280

Top soil :

Feet.

Brown, grading upward into red sandy soil_

Ripley formation:

Gray, weathering tan, glauconitic, fine clayey sand with many small white lime nodules and fossil fragments.

Gray, indurated, nodular limestone layer

Fine, dark to light gray, micaceous, carbonaceous marine, sandy clay with small white, nodular lime concretions

Alternating 4-6 inch gray, indurated, nodular limestone layers and beds 6 feet thick of gray, weathering tan, micaceous fine, carbonaceous, glauconitic, sandy clay containing Exogyra cancellata, Gryphaea sp., Ostrea falcata, Anomia tellinoides, Paranomia scabra (?) and others.

The same exposure has been described by Cooke $(1943$, p. 33), who gave a more complete list of fossils. Most of the fossils, however, were collected by Stephenson $(1911$, p. 188, 189) in cuts along the Seaboard Air Line Railroad 1/4 to 11/4 miles north of Renfroe, east of the highway. In addition to those listed by Stephenson, the following fossils were found during this survey: Ostrea falcata, 0 . mesenterica, Hamulus cf. H. onyx, Porifera (branched), shark teeth, and Halymenites major (thick, calcareous).

In material from these exposures, E. H. Rainwater (Herrick and LaMoreaux, 1944, p. 56), identified the following Foraminifera:

\section{Anomalina nelsoni W. Berry pinguis Jennings}

Bolivinopsis rosula (Ehrenberg)

Bulimina cf. B. quadrata Plummer

Bullopera sp.

Cibicides harperi (Sandidge)

Dentalina alternata (Jones)

basiplanata Cushman

pauperata D'Orbigny

vertebralia (Batsch)

Frondicularia sp.

Gaudryina rudita Sandidge

Globigerina cretacea D'Orbigny

Globigerinella aspera Cushman

Globotruncana cretacea Cushman
Gumbelina striata (Ehrenberg)

Gyroidina depressa (Alth)

Haplophragmoides sp.

Loxostoma plaitum (Carsey)

Marginulina texasensis (Cushman)

Nodosaria affinis Reuss

Pseudoclavulina amorpha (Cushman)

Robulus macrodiscus (Reuss)

navarroensis (Plummer)

pondi Cushman

spisso-costatus Cushman

Siphonina cf. prima Plummer

Textularia ripleyensis Berry

Vaginulina cf. V. suturalis Cushman webbervillensis Carsey 
The basal contact of the Ripley formation is found a mile north in cuts on this same highway. Approximately 180 feet of Ripley is exposed on this hill slope.

Marion County.-The Ripley cuesta trends northeastward across central Marion County and forms rolling land similar to that in southeastern Chattahoochee County. The Ripley formation is resistant to erosion, and it forms, especially on the high extension of the cuesta to the north, a deep-red soil mass that overlies sharply the loose gray Cusseta sand and contrasts markedly with the pale-hued soil of the Cusseta and that of the overlying Providence sand.

Four and three-tenths miles northeast of Buena Vista the following section is exposed in cuts on State Highway 41.

\section{Section on State Highway 41, 4.3 miles north of Buena Vista}

Ripley formation:

Feet

Sand, clayey, fine; weathers red; contains borings; grades downward into fine sand that shows concentric banding (probably weathered concretions)

Clay, hackly, carbonaceous; grades downward into fine sand with a ferruginous conglomerate at base. About

Cusseta sand :

Sand, pebbly, pale-gray, loose. About

One and a half miles northeast of Buena Vista on State Highway 137 is the following section (fig. 10) :

Section 11/2 miles northeast of Buena Vista in cut on State Highway 197

Soil :

Fieet

Sand

Providence sand:

Sand, coarse, light-red, massive. Altitude at base, 628 feet (by altimeter)

Unconformity.

Ripley formation :

Clay and fine sand, grading downward into micaceous sand with borings; about 20 feet below top, formation is somewhat fissile hackly clayey sand. Exposed.

The Ripley and Cusseta contact is near the foot of the hill, about 115 feet below the Providence and Ripley contact. Here the Cusseta is coarse loose very irregularly crossbedded sand containing clay lenses.

Taylor County.-The outliers that cap most of the hills in southern Taylor County are an eastward continuation of the cuesta of the Ripley formation in Marion County. Because of the resistance of the Ripley formation to erosion, some of the highest elevations in the Coastal Plain are along the crest of this ridge. A benchmark at Mauk, near the crest of the cuesta in the western part of the county, is 780 feet above sea level. A high projection of the cuesta to the north, 
near Butler, has been confused with the Clayton formation because of the deep-red color of the weathered marine beds of the Ripley. The cuesta slopes so gently southward, and its undissected remnants form such flat land, that it constitutes some of the most valuable agricul. tural land in the county. Some of the best exposures of the Ripley are found along U. S. Highway 19 from 2 to 12 miles south of Butler.

The contact of the Ripley formation and the underlying Cusseta sand is exposed at the crest of a hill 2.4 miles south of Butler.

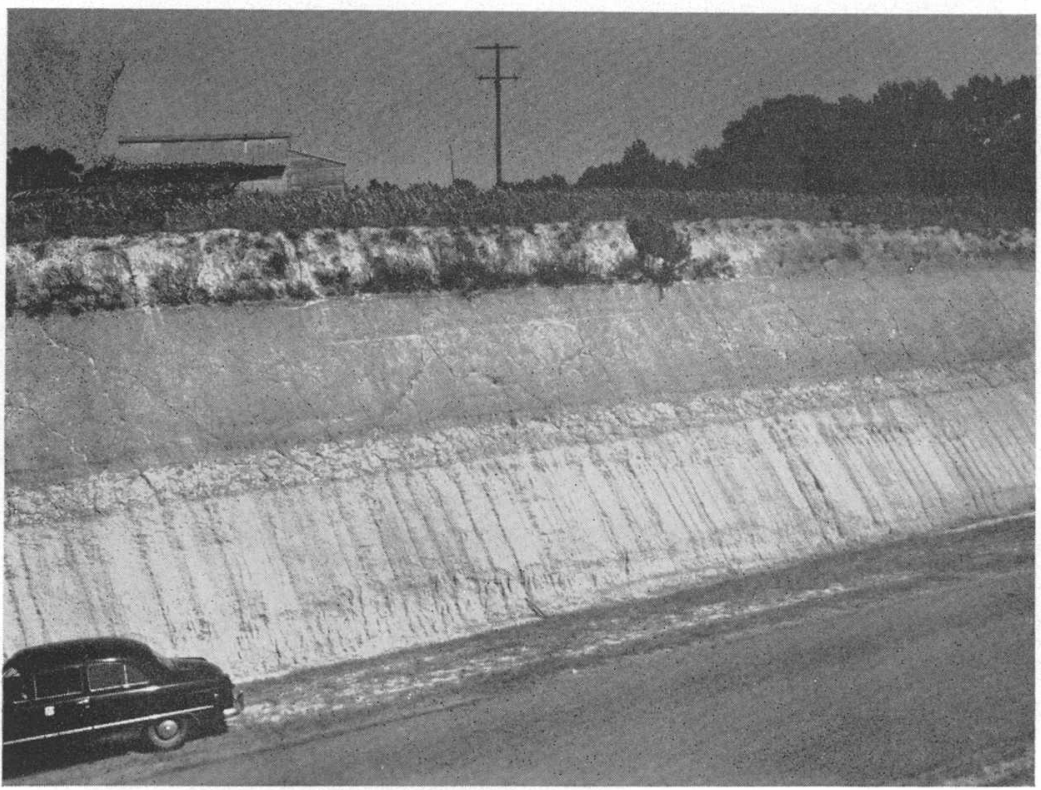

Figure 10.-Updip contact of the Ripley formation and the Providence sand. The Providence sand, covered with deep sandy soil, is slightly darker than the underlying Ripley formation. A 2 -foot bed of sandy clay at the top of the Ripley lies on clayey sand that extends to ditch level. North side of cut, State Highway 137, 11/2 miles northeast of Buena Vista, Marion County.

\section{Section 2.4 miles south of Butler on U. S. Highway 19}

Ripley formation :

Feet

Sand, very coarse, pale- to moderate-reddish-brown, ferruginous, irregularly crossbedded; contains indistinct borings of Halymenites and lenses as much as 1 foot thick of rariegated silty clay with mica flakes that weathers hackly to fissile but has subconchoidal fractures where less deeply weathered. The clay is horizontally banded (parallel to bedding) with moderate orange pink to moderate reddish orange. Sharp basal contact________-_-_-_-_-_

Cusseta sand:

Clay containing coarse sand, variegated, grayish to moderate-pink, spotted with grayish red purple, massive, jointed; conchoidal fracture; weathers along upper surface to pale orange and dark yellowish orange 
Schley and Macon Counties.-The Ripley crops out in the bottoms and on the low slopes of the larger creek valleys in Schley and Macon Counties. In Buck Creek valley across northern Schley County the Ripley formation is present as a large inlier. In the bottom of Whitewater Creek in Macon County, and along its tributaries to the northwest in Taylor County, typical Ripley material is exposed. Fossil prints were found in fine sand that grades upward into dark-gray clay about 20 feet above the bottom of Toteover Creek just south of the bridge on State Highway 128, 101/2 miles north of Oglethorpe. This locality is $31 / 2$ miles west of the place where A. D. Zapp found fossils on the banks of the Flint River, as reported by Cooke (1943, p. 34).

Crawford County.-The Ripley formation in southern Crawford County is a narrow wedge that is gradually overlapped toward the east by Tertiary rocks. Only in the extreme southern part is it overlain by Providence sand. Good exposures are found in the southern point of the county, north of the Central of Georgia Railway, and along the county road from Nakomis to Zenith. Along this road, redweathering clayey fine sand containing numerous borings lies below sand of the Tertiary that weathers deeper red, and rests abruptly on loose granular coarse sand of the Cusseta.

Following is a modified summary of a classic section where beds of the Ripley are overlain by Tertiary rocks and underlain by Cusseta sand, previously described by Stepenson (1911, p. 167) :

Section exposed in railroad cuts from Zenith north for a half mile

Tertiary rocks :

Feet

Sand, deep-red, massive; basal 2 feet is gravelly and contains silicified clay balls ; large irregular masses of ironstone at base. About-----

Unconformity.

Ripley formation :

Sand, fine, soft, irregularly laminated; thin films and very thin beds and lenses of clay grading downward into fine to coarse sand and thick beds of laminated clay. Sand contains very fine mica, is strongly crossbedded, and all lower beds dip strongly southward. Below a coarse sand lens is $\mathbf{1 5}$ feet of soft finely laminated sand. This grades downward into dark-gray carbonaceous clay containing plant remains. Clay layers are mixed with fine sand. Base of coarse sand and fine gravel here overlies irregularly the beds below. Approximately

Cusseta sand:

Clay, white, strongly mottled and spotted with irregularly concentric bands of light pink and purple, finely vermiculate to laminated.

Another thin wedge of Ripley lying beneath sand residual from the Tertiary is exposed 11/2 miles southwest of Union Chapel in the southern part of the county on a northward-trending county road. Beneath colluvial sand weathered from Tertiary strata is 6 feet of fissile clay and fine sand of the Ripley near the point where it wedges out 
below the overlapping Tertiary. About 30 feet of fairly typical but coarse light-red sand of the Ripley lies beneath darker red sand of the Tertiary about $11 / 2$ miles southeast of that locality and a half to 1 mile west of Wesley Chapel. This overlies about 30 feet of coarse sand and interbedded white clay of the Cusseta sand at the foot of the hill. In Crawford County there is a gradation in the Ripley formation in an easterly direction from fine to coarse sand, as well as a complete overlap of the overlying Providence by Tertiary strata.

A section showing a well-exposed contact of the Tertiary, the Ripley, and the Cusseta is in southeastern Crawford County on a northfacing valley slope of Indian Creek (a tributary of Mossy Creek), on a northward-trending county road east of State Highway 49 :

Section on a northward-trending road, east of State Highway 49, on south valley slope of Indian Creek

Residuum of' 'Tertiary rocks (Jackson ?) :

Feet

Clay, sandy, deep-reddish-brown. About

Tertiary rocks (pre-Jackson ?) :

Sand, red; indistinct borings of Halymenites and clay flakes, partially reworked. About

Ripley formation :

Sand, mostly fine, and thin clay beds; contains a bed of thin-bedded, carbonaceous clay, about 3 to 4 feet thick, near base, and coarse sand and granules at base

Cusseta sand:

Sand, coarse, pale-reddish-brown-weathering; contains white clay balls. Partially covered, but 15 feet well exposed at foot of hill. Exposed

Peach County.-A 20-foot wedge of very coarse Providence sand, containing clay balls, thin clay beds, and some fine gravel at its base, overlies fine to medium sand of the Ripley formation in the southwest corner of Peach County, about 0.9 of a mile east of the southernmost point on the Crawford County boundary, on a county road. The Ripley is slightly clayey and silty and contains borings.

Two and three-tenths miles northeast of Fort Valley, along State Highway 49, are good exposures of the coarse sand of the Ripley that contains abundant borings of Halymenites major. These and a number of other exposures in this area were studied by Stephenson and Thompson (1943, unpublished report). The sand ranges from coarse to fine, is light reddish brown, and contains small lenses of clay. It is hard and semi-indurated, not loose like most of the underlying Cusseta sand, nor is it so irregularly crossbedded or as coarse grained. Halymenites borings have not been found in the Cusseta east of Marion County. The Cusseta generally weathers to paler colors than this sand. The few wedges of Providence sand which have not been overlapped by the Tertiary formations indicate that the Providence in 
this area should be considerably higher than these exposures of the Ripley.

Seven-tenths of a mile farther along the same road, but at a lower elevation than the exposures 2.3 miles northeast of Fort Valley, 30 feet of very coarse granular sand contains abundant Halymenites major borings in some beds and clay balls in others. This is believed to be near the base of the Ripley formation.

On State Highway 49, half a mile southwest of Powersville, 41/2 miles southwest of Byron, road cuts show very coarse sand containing white clay balls (reworked pisolites) of Tertiary age, lying abruptly on light-red fine sand of the Ripley formation, clayey in places and soft, grading downward in about 4 feet to coarse loose sand. The exposures extend for about 25 feet or more downhill and show coarse sand containing abundant Halymenites. . A good exposure of the contact between the Tertiary and Ripley is in gullies just east of the road.

A thin wedge of Ripley, where it is not completely overlapped by the Tertiary, is found in the north end of the county 2 miles north of Byron, where the following section is exposed:

Section 2 miles north of Byron, half a mile south of Waltons Mill

Tertiary rocks :

Sand, very coarse, dark-red; contains clay films

Ripley formation :

Sand, very fine, micaceous, clayey____. 12

Covered interval. About._._. 24

Cusseta sand (?) :

Sand, very coarse, clayey, white; contains fine gravel and clay balls. About

Down the hill is exposed more than 100 feet of medium to coarse sand containing white clay beds as much as 12 feet in thickness.

Houston County.-In road cuts about a quarter of a mile southwest of Elberta Station on the Southern Railway, just south of Echeconnee Creek along the north edge of the county, about 15 feet of a coarse red-weathering sand containing Halymenites borings appears beneath the deeper red sand of the Tertiary that blankets the uplands of most of the county. Near the base of the exposure is carbonaceous clay and below it is fine gravel. This exposure is typical of the Ripley formation of counties to the west. It lies directly on very coarse crossbedded sand that contains abundant clay balls. The latter, presumably the Cusseta sand, is well exposed about 300 yards east of the road cuts in a sandpit, where about 35 feet of loose very coarse to gravelly sand contains clay grains (weathered feldspar), clay balls, and a high percentage of mica. Half a mile farther south the following section is exposed in cuts on a road leading southward from State Highway 247 : 
Section on road leading southward from State Highway 247 three-quarters of a mile southeast of Elberta

Ripley formation (?): $\quad$ Feet

Sand, clayey, mostly soil, light-yellowish-brown. Coarse sand and

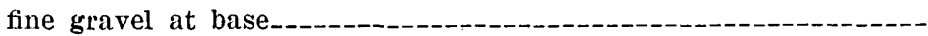

Clay, very pale-pink to lavender, very impure; contains fine sand, mica; has many plant impressions and small masses of plant matter.

Sand, fine to very coarse

From the north-central part of the county south to the vicinity of Perry, firm, brittle white clay, with fine sand, grading downward into clean white very fine sand, lies immediately under the redweathering coarser sands of the Tertiary. These beds are not far beneath the fossiliferous Twiggs clay of Jackson age, as shown in a clay prospect a mile northwest of Claybed. This material, formerly considered of Cretaceous age, is considered by Herrick and LeGrand (personal communication) to be of Tertiary pre-Jackson age.

Bibb County.-On high hills 11/2 miles west of Skipperton, about 9 miles southwest of Macon, between Tobesofkee and Echeconnee Creeks, are exposures of the Ripley formation consisting of coarse red sand containing Halymenites borings and clay balls. Most of the exposures are in cuts along an abandoned railroad right-of-way. From 1 to 2 miles west of this locality, fine red-weathering sand contains films and small clay balls and less distinct Halymenites borings. This sand is typical of the Ripley to the southwest and extends for about 3 miles along the crest of the ridge between the creeks.

East of the Ocmulgee River.-In Twiggs County along U. S. Highway 129 , from $21 / 2$ to 4 miles east of the Ocmulgee River, Stephenson and Thompson (1943, unpublished report) found about half a dozen localities of coarse red sand containing Halymenites borings. These localities are generally downhill from arkosic coarse sand containing white clay that is overlain by deep-red materials weathered from Tertiary sediments. The sand with borings is typical of the Ripley west of the river and is considered an eastward extension of that formation. This sand could not be traced farther east because of the lack of exposures in downhill positions, the strong overlap of the Cretaceous by Tertiary formations, and the eastward change in facies of the Ripley from marine to less distinctly marine.

\section{PROVIDENCE SAND}

\section{GENERAL FEATURES}

Name.-Veatch (1909, p. 86) first described the Providence sand and assigned it to the upper member of his Ripley formation. He included in the Providence sand all Cretaceous sediments above his Renfroes marl. The Providence sand was named for exposures in the 
deep gullies at Providence Church, 7 miles west of Lumpkin, Stewart County, Ga. In 1911, Stephenson (p. 192-200) described it as a member of the Ripley formation. Stephenson and Monroe (1938, p. 1652 ) considered the Providence sand to be a separate formation because of the widespread unconformity that separates it and its western correlatives from the underlying Ripley formation.

Areal extent.-The Providence sand can be traced in a broad belt of outcrop from the Chattahoochee River in Clay and Quitman Counties northeastward to the Flint River valley in Peach and Macon Counties. Farther east it is present as inliers in the deeper stream valleys in Peach and Houston Counties as far east as the Ocmulgee River valley. East of the Ocmulgee River it cannot be distinguished generally from the underlying Cretaceous formations, but coarse sand immediately below the Tertiary rocks in western Twiggs County is probably part of this formation, and, indeed, some of the kaolin deposits may be of this unit.

Lithologic character.-In western Georgia the basal part of the Providence sand is distinctly different from the upper part. The basal part is highly micaceous carbonaceous dark-gray marine silt or very fine sand and is here correlated with the Perote member of the Providence sand of central and eastern Alabama (Eargle, 1950). Typical exposures of the member are in the vicinity of the village of Perote in southern Bullock County, Ala., about 35 miles west of the Chattahoochee River. There the Perote member is highly fossiliferous in contrast to the unfossiliferous coarse sand of the upper member. At the type locality the Perote member constitutes about half the Providence sand, which is about 350 feet thick. Farther east in Alabama the member becomes thinner; immediately east of the Chattahoochee River in Georgia it is only about 35 feet thick, and at Providence Canyons it measures 33 feet (fig. 11). A thin bed, only 15 feet thick, consisting of fine sand with a basal coarse sand, intervenes between the coarse sands of the upper Providence and the Ripley formation in Schley County, but the member has not been recognized farther east. From here eastward it apparently merges with the upper member by a change in facies to a coarse sand.

The upper part of the Providence is distinctly marine down the dip in the valleys of the Chattahoochee River and tributary creeks and consists of some fine- and some coarse-sand beds, as well as lenses of dark-gray clay. The material is firm, in contrast to the loose sand of the updip areas, and contains a number of hard calcareous and nodular layers. Fossils are profuse in some beds. Very fossiliferous beds are at several localities in the valley of Pataula Creek and vicinity in northwestern Clay and in southern Quitman Counties. Up the valley to the northeast, marine clays and fine sand containing abun- 
dant molds of fossils are present in the ditches of almost every road that crosses the main valley of Pataula Creek in Randolph and southeastern Quitman Counties.

From these downdip localities in which only marine beds are exposed at altitudes of about 100 feet above sea level, the Providence slopes gradually upward to the north, and, with a thin capping of

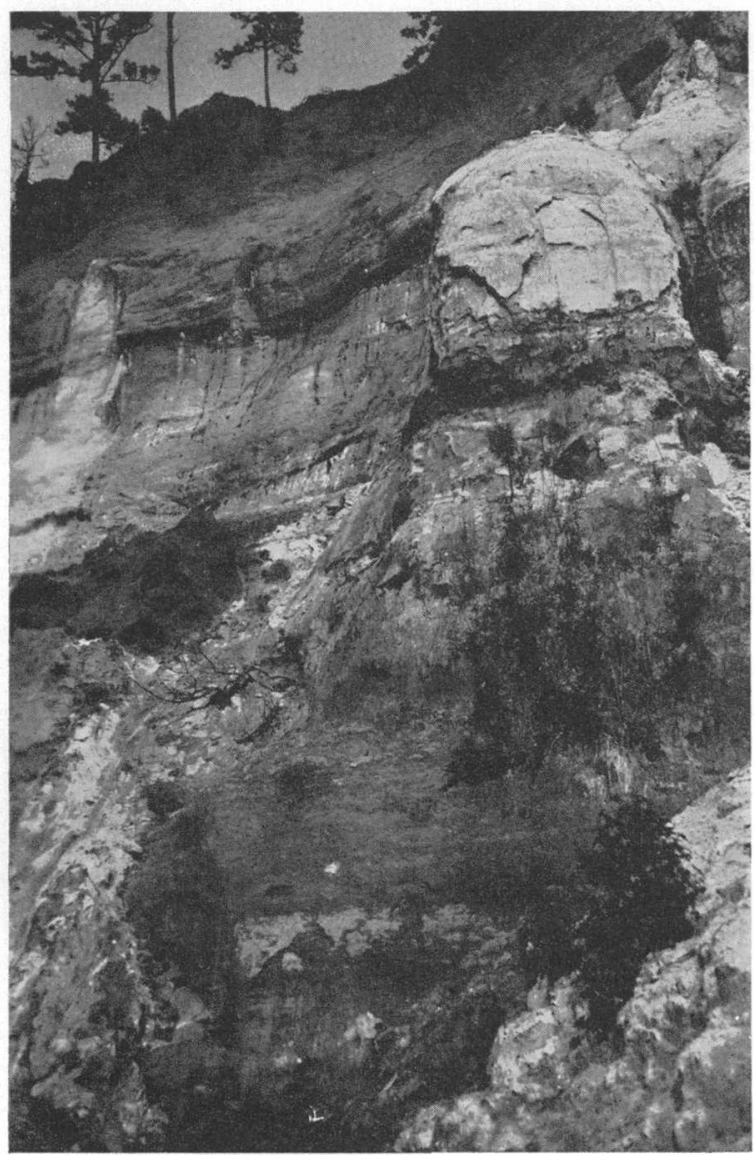

Figure 11. - The lower part of the Providence sand, near the bottom of Providence Canyons, 7 miles west of Lumpkin. The upper, or coarse sand, member of the Providence sand, in the upper one-third of the exposure, lies conformably on carbonaceous and micaceous silt of the lower, or Perote, member in the lower two-thirds.

Tertiary residuum, forms a north-facing cuesta as high as 600 feet above sea level in central Stewart County. The cuesta front reaches a maximum altitude of 650 feet in central Marion County, northern Schley County, and southern Taylor County.

In updip outcrops, the upper member, chiefly of coarse sand, is generally arkosic and contains minor lenses of white to varicolored 
clay. The sandy beds are white to pale variegated purplish red, reddish brown, and yellow. Some layers are pink or purple tinted, depending on the ferruginous content or the kind and percentage of clay. The clay occurs both as thin white lenses, in places mottled with yellow, red, and purple, and as disseminated kaolinized feldspar grains or as balls. The sands are crossbedded, loose, and contain indistinct borings resembling Halymenites. The sands forming the steep front of the high cuesta are highly susceptible to erosion, but once the gullies are trenched their walls stand almost vertical for years. Many of them are more than 100 feet deep and furnish some of the thickest and best exposed sections of bedrock (although soft and exceedingly friable) observable at one station anywhere in the Coastal Plain. Too, they are hardly excelled for their spectacular display of varicolored beds of sediment anywhere except in the badlands of arid climates. Such are the gullies at the type locality of the formation, near Providence Church, 7 miles west of Lumpkin, Stewart County. Even more spectacular ones are found north of Lumpkin and to the south in Quitman County.

East of Schley County most of the Providence is overlapped by Tertiary beds, and only a few outliers of the Providence sand are found north of the Tertiary areas. The lower part of the Providence is exposed in outliers in southeastern Taylor and northern Macon - Counties. In Macon County the upper part is exposed in many places in the valley of the Flint River where the Tertiary has been stripped off, but west of the river in that county extensive terraces cover a large part of these outcrops. Between the Flint and Ocmulgee Rivers the Providence is generally covered by the Tertiary, except in Peach and Houston Counties where deeper stream valleys expose its coarse sand and white clays.

East of the Ocmulgee River, along U. S. Highway 129 on the west edge of Twiggs County, very coarse sand containing white clay balls, believed to be of Providence age and overlying pale-red coarse sand, with borings, that is tentatively assigned to the Ripley formation, is present immediately below beds of Tertiary age (Stephenson and Thompson (1943, unpublished report).

Coarse sands near the top of the Cretaceous section in Twiggs County are questionably referred to as the Providence, as are also extensively mined white clays in Twiggs, Wilkinson, and Washington Counties. These clays may be the eastern equivalents of the thinner lenses of white clay found in inliers in Peach and Houston Counties.

Thickness.-The outcropping Providence sand has a maximum thickness in the Chattahoochee Valley of about 180 feet, of which about 145 feet is coarse sand of the upper member and about 35 feet at the base is fine sand of the Perote member. The thickness of the forma- 
tion decreases toward the east, measuring about 125 feet in southeastern Marion County. Because of an abrupt change in strike of the Tertiary rocks in northwestern Macon County, an overlap by the Tertiary rocks begins there, progressively diminishes the outcrop area of Providence sand toward the east, and precludes significant measurements of the formation on the surface. A thickness of 144 feet was assigned by the author to the Providence sand in Tricon Minerals, Inc., Gilbert no. 1 well, near Perry, Houston County, chiefly on the basis of white clay in unwashed samples of coarse sand from above fine marine sand of the Ripley formation.

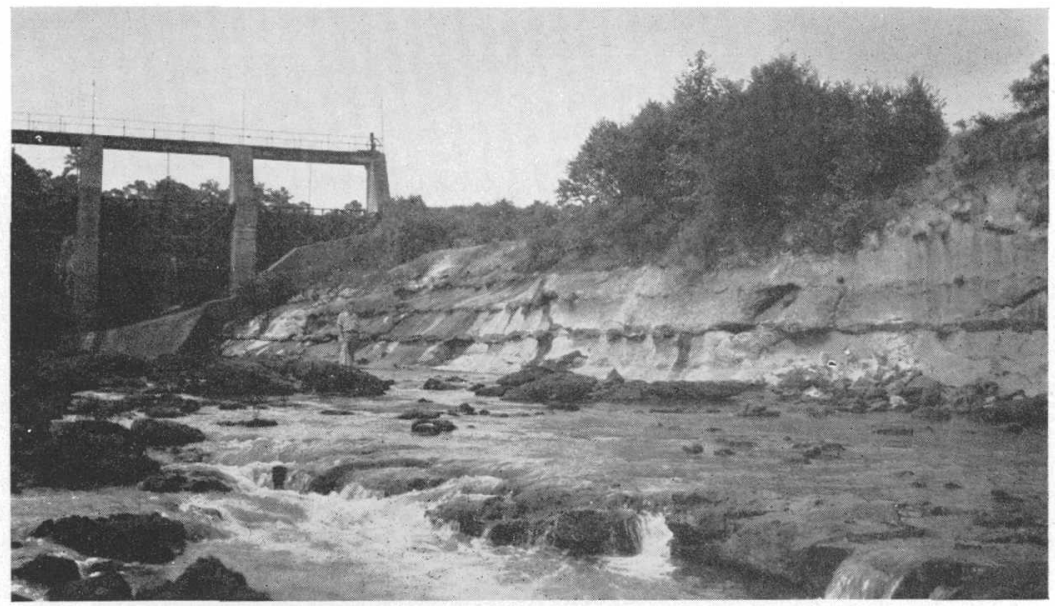

Figure 12.-A downdip exposure of marine fossiliferous beds of the Providence sand. Pataula Creek, below Credilles Mill, east of State Highway 39, northwestern Clay County.

Clay County.- The marine facies of the uppermost beds of the Providence sand is well exposed in the bottom of the valleys of Pataula and Drag Nasty Creeks in the northwestern part of the county. These beds pass under the water level of the Chattahoochee River about 5 miles below the mouth of Pataula Creek (Cooke, 1943, p. 36). Fossils collected from classic localities along this creek and nearby along the Chattahoochee River have been listed by Stephenson (1911, p. 180, 184-186) and Cooke (1943, p. 35-37).

A very accessible site where numerous fossils can be collected is the Credilles Mill locality on Pataula Creek, below the hydroelectric dam and above the bridge of State Highway 39. Among the most abundant fossils are Exogyra costata, Trigonia sp., Turritella trilira, Glycymeris sp., and Cardium sp., but ammonites and other mollusks, as well as echinoids, are present. The fossils are found chiefly in and just above a calcareous coarse sand ledge about 2 feet thick which forms waterfalls in the stream (fig. 12). 
A nearly complete specimen of an ammonite with its nacreous shell still partly preserved was collected from a thin sandstone bed 1 foot higher than the one forming the falls below the dam.

The following Foraminifera were identified from material from this site by E. H. Rainwater (Herrick and LaMoreaux, 1944, p. 61) :

Foramifera from Providence sand, Credilles Mill, Pataula Creek, Clay County, Ga.

Fossil

Anomalina cf. A. clementiana D'Orbigny

Ceratobulimina cretacea Cushman and Harris

Gaudryina sp., small

Guttulina sp., small

Loxostoma plaitum (Carsey)

Siphonina cf. prima Plummer
Frequency Abundant.

Do.

Rare.

Do.

Do.

Do.

Rainwater also observed that an abundant and varied ostracod fauna is present.

On the north bank of Pataula Creek at its junction with the Chattahoochee River calcareous coarse sandstone ledges overlie dark-gray highly micaceous laminated very fossiliferous clay and silt. Nacreous shells of pelecypods and ammonites were found in the lower material. The overlying calcareous coarse sandstone contains the same genera of echinoids as do the hard ledges of the Credilles Mill locality.

Quitman County.-The Providence sand is the surface formation in fully a half of the total area of Quitman County. The downdip marine facies of the formation is found in the southeast third of the county and is especially well exposed in the valley of Pataula Creek and its tributaries.

Southeast of the bridge over Pataula Creek in the southeastern part of the county, in the ditch of the highway from Georgetown to Cuthbert, is a small exposure of very fossiliferous upper Providence sand that is very micaceous, dark gray, and clayey and silty. The abundant fossils, especially gastropods and thin-shelled pelecypods, are delicate but well preserved, and can, if carefully done, be collected for study. Tentatively identified were T'urritella bilira, Anomia argentaria, Liopistha cf. L. protexta, and Trigonia sp. This exposure is 40 feet below the probable Clayton and Providence contact in a poor exposure in a highway cut up the hill to the south.

The updip facies of the Providence sand is exposed on the dissected flanks of the cuesta, which slopes gently southward and forms a large part of the north two-thirds of the county. This cuesta is capped with a residuum of Tertiary formations. On the steep flanks of the dissected cuesta are gullies more than a hundred feet deep that are among the largest in the eastern United States and are similar to those at the type locality of the Providence sand in Stewart County, the adjoining county to the north. Most of the gullies expose a complete section of Providence sand. 
Unusually large gullies on the W. E. Graddy and the F. J. Graddy Farms about half a mile west of Rocky Mount Church afford fine exposures of the Providence sand (fig. 13). They are $71 / 2$ miles northeast of Georgetown, just north of an eastward-trending section of the road that connects Avreys Store on the Florence-Georgetown road, near Bustahatchee Creek, with State Highway 27 near Rocky Mount

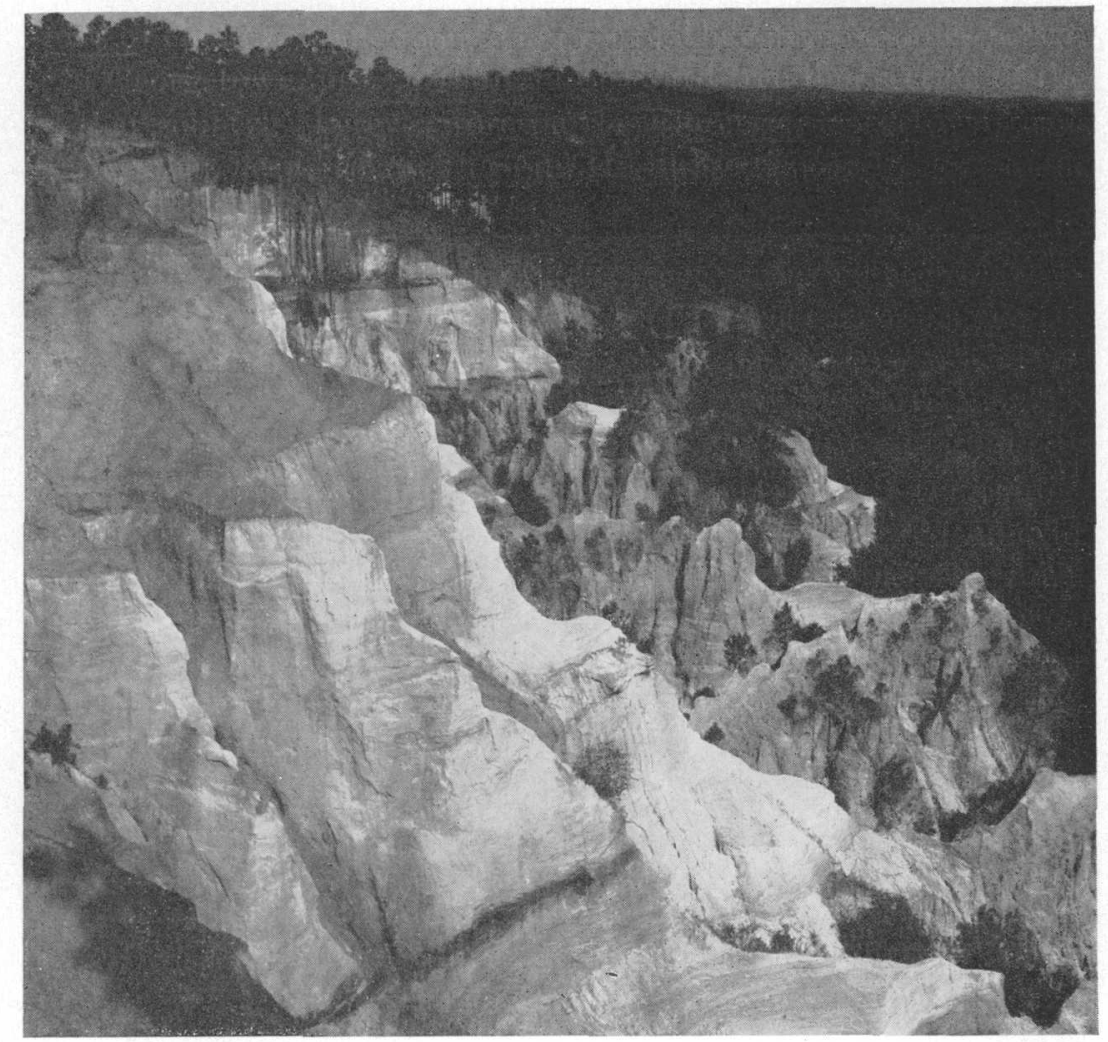

Figure 13.-Exposure of the Providence sand along gullied south wall at the head of a tributary of Bustahatchee Creek. The darker bed at the top is a dark-red residuum of calcareous rocks of the Paleocene Clayton formation. It sharply overlies pale variegated loose sand of the Providence which stands generally vertical and extends to the bottom of the gully. Graddy Farm, 71/2 miles northeast of Georgetown, Quitman County.

Church. Another large gully was reported on the Stout Bennett Farm, $4 \frac{1}{2}$ miles northeast of Georgetown, in the headwaters of Soapstone Creek. The most active gully observed is on the Henry Cooper Farm, 91/4 miles northeast of Georgetown and half a mile west of State Highway 26, at the Stewart County line. Its head has been advancing upslope about 100 feet a year since drainage from a considerable area on the plateau surface was directed into it. 
These canyons advance with amazing rapidity, hundreds of feet in a few decades. while cutting into the steep sides of creek valleys, but as the gully heads approach the divide, their rate of growth diminishes greatly unless considerable runoff water is directed into them from adjoining fields or roadways.

In the vicinity of Hatcher in the southern part of the county are several exposures of Providence sand. The least weathered is $11 / 2$ miles south-southwest of the village, 0.2 of a mile south of Pataula Creek, in a gullied bed of an abandoned road. Here, in gray weathered loose clayey sand is an indurated ledge of calcareous gray clay containing coarse sand and abundant fossils, of which the following were found: Exogyra costata, Cardium sp., Glycymeris sp., Trigonia sp., Turritella sp., and other gastropods, an ammonite, an echinoid, phosphatized bone fragments, and phosphate grains.

Randolph County.-The downdip facies of the Providence sand is found in the valley of Pataula Creek in the northwest corner of this county. About 1.6 miles northwest of Springvale, 35 feet of clayey sand of the Providence underlies highly weathered contorted ferruginous residuum of 'Tertiary strata that had contained a high percentage of carbonate rock. The Providence is slightly clayey very fossiliferous coarse sand containing fine gravel in places. Only the prints of fossils were observed, and they include the following species: Exogyra costata, Turritella trilira, Cardium cf. vaughani, Cardium sp., Linearia cf. metastriata, Gyrodes sp., Tellina sp., Liopistha sp., and many other pelecypods and gastropods.

Stewart County.-The Providence sand, with a thin capping of residuum of Tertiary rocks, underlies the high cuesta that extends through the county from the southwest to the northeast corner. The back slope of the cuesta slopes gently southward but is deeply incised by the headwaters of creeks tributary to the Chattahoochee River, especially Hodchodkee and Pataula Creeks. Also deeply dissecting the cuesta are Roods and Turner Creeks on the west and Hannahatchee Creek on the north. In the headwaters of Turner Creek are the well-known Providence Canyons, constituting the type locality of the Providence sand. These canyons, like those in Quitman County to the south, have had a period of extremely rapid growth in approximately the last 50 years, but their present advance is generally slowing down, and they are becoming revegetated to a remarkable degree. Large trees growing in the bottoms of many of the gullies almost hide the bare walls. Some of the gullies have been planted to kudzu and other vegetation. These treatments have practically halted growth of the gully heads unless concentrated flows of water are diverted into them from roadways and terraced fields. 
The following section is exposed in Providence Canyons in the head of the gully south of Providence Church, the type locality of the Providence sand (figs. 14, 15).

Section in Provilence Canyons, 7 miles west of Lumpkin, Stewart County, south of the road from Lumplin to Florence and south of Providence Church (altitude of road at beginning of section, 637 feet)

Tertiary sediments (residuum from calcareous rocks of the Clayton formation of Paleocene age) :

Clay, sandy, reddish-brown, ferruginous, massive to very irregularly bedded

Unconformity.

Providence sand :

Upper member :

Sand, coarse, broadly crossbedded, kaolinitic; beds range from almost white to pale purple, orange, yellow, and red; slightly deeper shades and finer sands lower in the gullies; some beds laminated, some contain Halymenites major borings, and some contain elliptical kaolinitic clay balls as much as 2 inches long. By altimeter

P'erote member (see fig. 11) :

Clay, yellow, lenticular.

Sand, fine, yellow (stained with iron oxide), very friable; contains mica and kaolin grains

Clay, dark-gray, very carbonaceous (megascopic plant remains common), micaceous, firm; some thinly laminated, very fine, sand streaks containing small clay chips and balls. Grades into bed below

Sand, very fine, light-gray; firm but friable.

Unconformity (?).

Ripley formation:

Sand, fine, dark-gray, slightly indurated, firm; contains fine mica and numerous fossil prints (chiefly mollusk). Exposed to top of alluvial fill in gully bottom

Other large gullies similar to the type south of Providence Church notch the cuesta $21 / 2$ to $41 / 2$ miles north of Lumpkin. The one $21 / 2$ miles north of Lumpkin is especially impressive for its size, depth, and rate of growth at its heads. It is just off a county road east of U. S. Highway 27. Others are 5 miles north-northeast of Lumpkin along the fringes of a narrow projection of the cuesta to the north and southwest of Brooklyn in northeastern Stewart County. A large gully 10 miles southwest of Lumpkin on State Highway 27. half a mile east of Sanford, was shown in an illustration by Stephenson $(1911$, pl. 18, p. 208) and described as being $101 / 2$ miles northeast of Georgetown.

Marion and Webster Counties.-Outcrops of Providence sand overlain in part by Tertiary formations occupy the southeast: $339546-55-6$ 


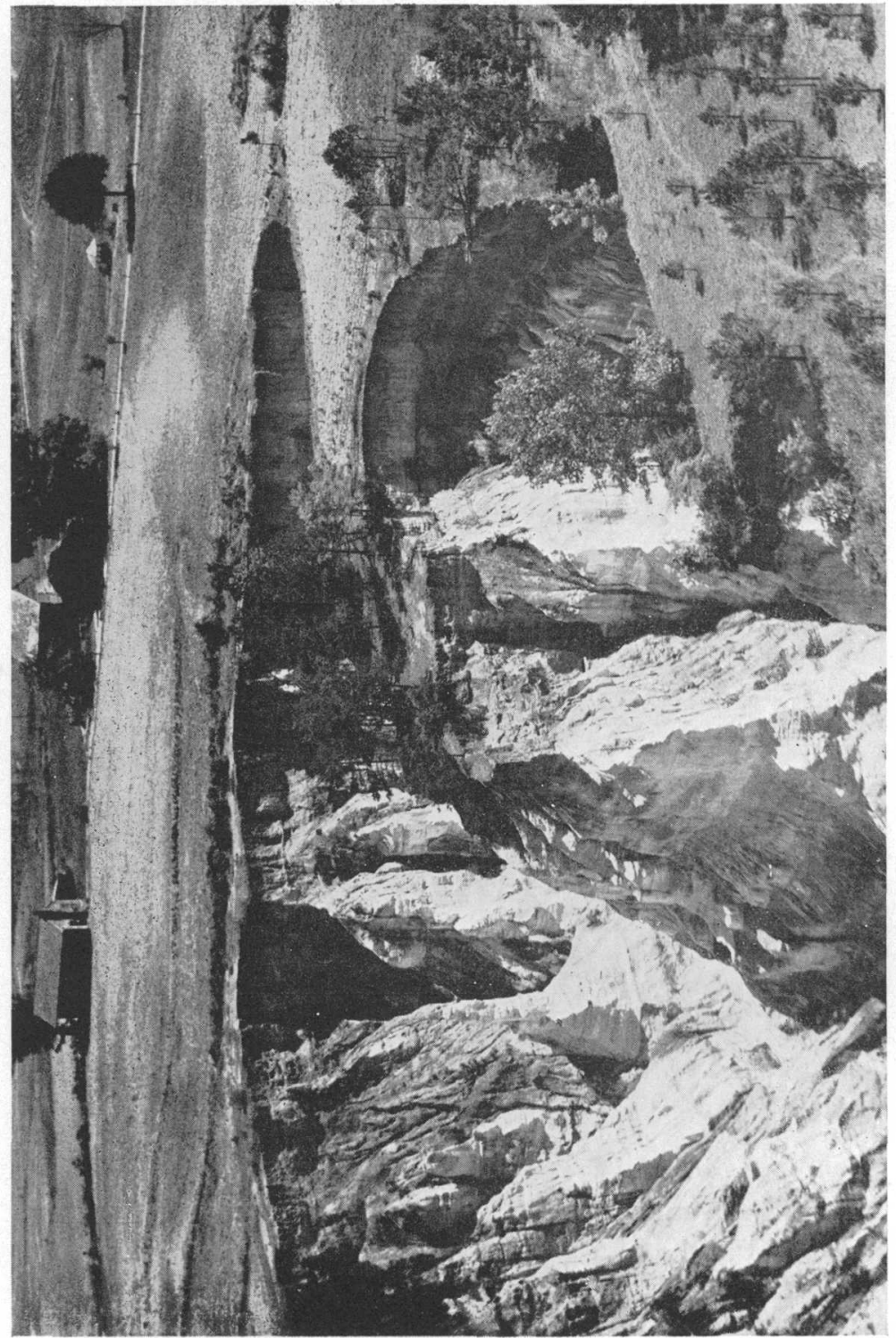

옹음 S ลิ 응 ๘ $\stackrel{3}{\exists} \approx$ \% $A$ 藏这 ० 4 ஏ ขี

क

2.

实

용 흉 范 出茄 要要 胥莺 की

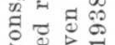

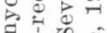
运要 ¿

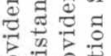
원유 항 당 觉

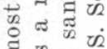
औ. 공 पू ( )

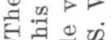
$1+\vec{E}$ +i 国 


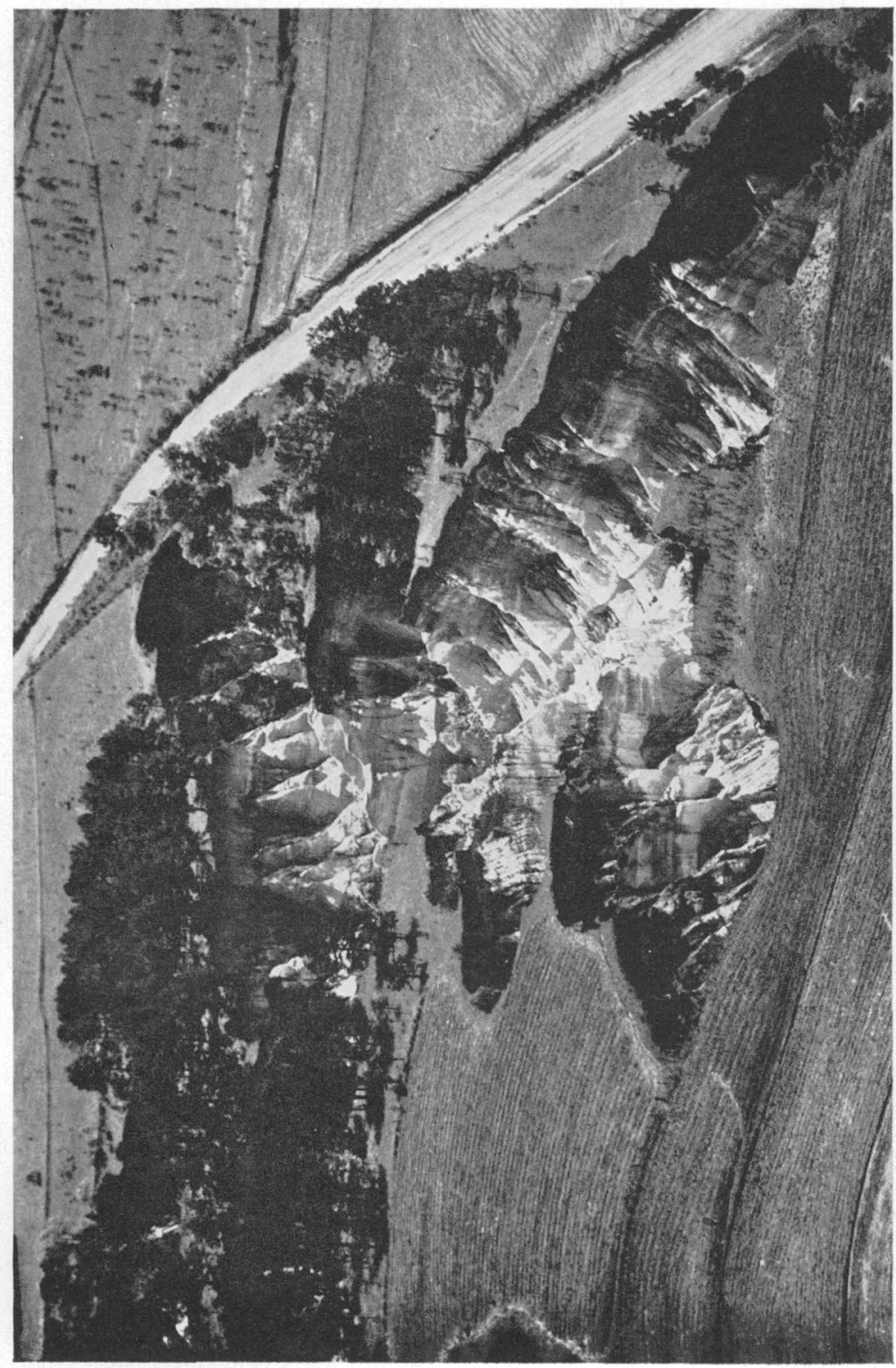

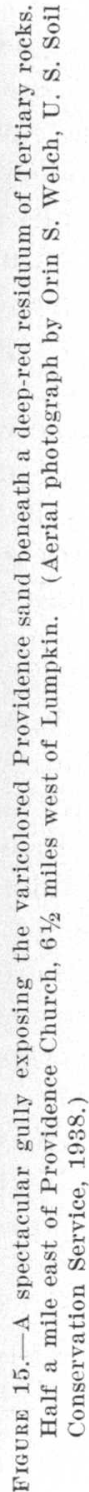


third of Marion County and the north half of Webster County. The Providence projects southward in the valleys of Kinchafoonee and Lanahassee Creeks and dips beneath the flood plain south of their junction in the vicinity of Preston, the county seat of Webster County. In downdip locations in Webster County the Providence is chiefly coarse sand that locally contains abundant Halymenites borings. In the northern part of the county, exposures of the contact with the underlying Ripley formation can be seen on the valley slopes of the headwaters of Kinchafoonee River.

In updip areas in Marion County the outcrop area of the Providence consists of rolling high hills covered with a blanket of loose pale sand. Beneath the soil the bedrock weathers to pale-red sand that contains lenses of white to varigated clay. The clay lenses seem to be concentrated near the top and near the base of the formation. The pale-tinted sediments of the Providence stand out in contrast to the deeply colored, reddish-brown 'Tertiary residuum above the dark-gray (unweathered) to red (weathered) beds of the underlying Ripley formation.

Taylor, Schley, and Macon Counties.-In these counties west of the Flint River, the Providence sand has the same general characteristics as in Marion and Webster Counties except that the downdip outcrops show very few, if any, of the distinctly marine characteristics that they do farther west.

Providence sand caps only the higher hills in the southern part of Taylor County, but it forms the larger part of the northwestern quarter of Macon County, where it occupies most of the valley sides of the creeks tributary to the Flint River. It underlies most of the extensive terrace lands adjoining the Flint River on the west. In downdip outcrops the Providence is a coarse sand that contains clay balls and conspicuous beds of pale variegated clay.

On a hill slope south of Buck Creek, $43 / 4$ miles north-northwest of Ellaville, the county seat of Schley County, the following section is exposed.

\section{Section $43 \% 4$ miles north-northwest of Ellaville}

Providence sand :

Upper member :

Feet

Sand, coarse, light-red; contains clay balls and thin platy ironstone; very coarse sand and fine conglomerate at base. Average altitude at base, $\mathbf{4 1 0}$ feet (by altimeter). From top of hill, about

Perote member:

Sand, coarse, pale-red and gray, fine and irregular crossbedding; contains thin white clay lenses 2 inches thick, tubular ironstone masses, and Halymenites major borings. 
Section $43 \% 4$ miles north-northwest of Ellaville (Continued)

Unconformity.

Feet

Ripley formation:

Clay, dark-gray to black; fine sand and mica in the upper 6 feet; grades downward at about 15 feet into micaceous clayey fine sand. To valley bottom

Eastward from north-central Schley County, the Tertiary formations strike more northeasterly than in the westernmost counties of Georgia and, progressively overlapping the Providence sand in an easterly direction, diminish the exposed areas of that formation.

Counties east of the Flint River.-East of the Flint River, Tertiary sediments overlap most of the Providence sand séction. In northern Macon County only a thin wedge, about 30 feet thick at most, remains uncovered. In Peach and Houston Counties, however, the deeper tributaries of the Ocmulgee River expose the Providence. In that area the formation contains appreciable deposits of white clay with much coarse sand. In downdip areas in Houston County the observable Providence consists chiefly of coarse sand having a few borings. Across the Ocmulgee River in Twiggs County coarse sand beneath high uplands capped by Tertiary sediments is believed to be Providence sand. Below these higher exposures are coarse red-weathering sands that contain Halymenites borings and are probably the equivalent of the Ripley formation west of the Ocmulgee River.

Six of the better exposures of the Providence sand between the Flint and Ocmulgee Rivers are described in the following.

Two miles west-northwest of Marshallville, Macon County, a 30foot section of Providence sand intervenes between coarse sand of the Tertiary and fine sand of the Ripley. Here is crossbedded highly ferruginous very coarse sand to fine gravel containing thin beds of slightly clayey fine sand and Halymenites borings.

Three miles northwest of Marshallville, west of the county road, are large gullies that expose the wedge of Providence sand between Tertiary rocks and the Ripley formation. Here, deep-reddishbrown clayey sand of the 'Tertiary overlies white to light-red coarse sand of the Providence. One thin lens of pale-red-purple massive clay about 2 feet thick lies about 20 feet below the contact of the Tertiary and Cretaceous. In the bottom of the gullies fine sand of the Ripley is exposed, but the Providence and Ripley contact is obscured by colluvium. Large blocks of ferruginous conglomerate are scattered on slopes below the contact. In this area the Providence is about 30 feet thick.

In the southwest corner of Peach County a thin wedge of Providence lies beneath the red-weathering Tertiary deposits and the small inlier of the Ripley in the headwaters of Big Indian Creek. 
On the road from Fort Valley to Nakomis, 4.8 miles west-southwest of Fort Valley and 0.2 of a mile west of Matthews Church and School, light-reddish-brown Tertiary sand containing scattered gravel overlies white clay and sand of the Providence, which grade downward into white clay almost free of sand. About 6 feet of the clay is exposed.

In a sandpit on the same road as the preceding locality and 0.3 of a mile west-southwest of Fort Valley, the Providence sand consists of crossbedded sand that varies from fine and silty to very coarse and that contains rounded pebbles up to 1 centimeter in diameter. The fine sand is laminated, light pink to light yellowish brown, and contains clay balls and borings of Halymenites major. About 20 feet is exposed. Two-tenths of a mile west of the pit this coarse sand, with much fine gravel near the base, overlies irregularly 3 feet of laminated fine to medium sand and clay containing borings, of the Ripley formation.

In a railroad cut 0.2 of a mile east of State Highway 49, 31/2 miles southwest of Fort Valley on the Peach-Macon County line, is an exposure of 5 feet of coarse sand of the Providence containing white, pink, or lavender clay lying below Tertiary formations.

In valleys east of Fort Valley are several inliers of Providence sand consisting generally of white clay, mottled with pale red, and coarse sand. The contact of the Providence with the underlying Ripley formation was observed at one locality 0.7 of a mile south of Ohio Station on the Central of Georgia Railway and $4 \frac{1}{2}$ miles northeast of Fort Valley. Near the foot of the north hill slope leading down to Massey Creek, coarse sand and fine gravel of the Providence overlies soft fine sand and laminated silty clay of the Ripley. This locality was the easternmost point at which the basal contact of the Providence was observed during this survey.

In eastern Peach and in Houston Counties the Providence sand is generally overlapped by the Tertiary sediments. In a few places the streams have cut beneath the sands and residuum of the Tertiary and through the superficial valley fill sufficiently to expose the Providence sand. One of the best examples of this type of exposure is just below the dam of Houston Lake, 5 miles northeast of Perry, Houston County. A thick coarse-grained ferruginous sandstone in the bed of the creek there is almost certainly of Providence age:

Excellent exposures of coarse to fine crossbedded sand containing occasional borings of Halymenites major are in large pits 0.1 of a mile south of Bay Gall Creek, 3 miles south of the railroad station at Warner Robins Air Base (formerly Wellston) in northern Houston County. On the basis of its altitude and general characteristics the sand is assigned to the Providence. Near its base the sand contains 
pebbles as much as 1 inch long, and near its top are lenses of fissile clay weathering pale pink. The fine sands have only a few borings. One lens as much as 3 feet thick is thinly bedded rippled clay and sand. The clay contains considerable comminuted plant material. A few beds are made up mostly of clay balls, some of which are white porous brittle kaolin pebbles as much as 4 inches long. This exposure is considered by the author to be near the base of the Providence sand in a downdip location.

The Providence sand probably would appear beneath the Tertiary in the vicinity of Warner Robins Air Base, but in this vicinity broad terraces of the Ocmulgee River mask bedrock formations. An exposure of mottled varigated brilliantly colored clay, believed to be of the Providence, underlies Tertiary formations west of the airbase in the headwaters of Bay Gall Creek. The following section is exposed east of the creek:

Section $21 / 2$ miles southwest of Elberta Station, 21/2 miles west of Warner Robins

Tertiary sediments:

Jackson age (?) :

Feet

Sand, red, massive; in part colluvially reworked. About____._.- 10

Claiborne age (?) :

Clay and fine sand interlaminated; contains Halymenites major; grades downward into white sand containing borings and clay grains and films; lower few feet of sand is fine to coarse, with basal beds of fine gravel.

Providence sand (?) :

Clay, massive, intricately mottled and banded, pale-purple, red, and very-light-gray; upper part contains abundant borings filled with coarse sand from above; grades downward into very pale-pink to cream or nearly white clay; lower part slightly sandy; basal part is very deeply mottled with deep purplish red and contains several lenses of fine sand. Exposed, about.--

White clay grading downward into fine to very fine sand, exposed beneath red Tertiary residuum in a number of places in north-central Houston County, was considered by some geologists to be of Providence age, but is now regarded as Tertiary by Herrick and LeGrand (personal communication). This assumption is supported by the altitudes of the outcrops in relation to the regional structure as projected into this county from the west, on lithologic character, and on the fact that the clay lies on coarse sands that are typical of the basal Tertiary in this area.

\section{UNDIFFERENTIATED CRETACEOUS ROOKS}

Most of the beds of. the Cretaceous section east of the Ocmulgee River are so similar that it has not been possible to map separate formations. In earlier reports the Cretaceous strata east of the Ocmulgee River have been assigned to the Tuscaloosa formation, but 
it now appears that only the basal part of these beds in central Georgia, possibly a few tens of feet, can properly be assigned to the Tuscaloosa formation. Most of the Cretaceous formations of the Chattahoochee region may be represented in eastern Georgia, but if so, all look so much alike that they cannot be readily differentiated.

From the Ocmulgee River to the Oconee River the outcropping Cretaceous beds form little more than a rim along the inner edge of the overlapping Tertiary strata. East of the Oconee River and up the dip, Tertiary strata completely overlap the Cretaceous and lie directly on the crystalline rocks of the Piedmont Upland. This relation shows well on the long northward projections of the Tertiary along high interstream divides. Down the dip, the Cretaceous beds crop out along flanks of the Tertiary areas and in stream bottoms, forming a wedge between the Tertiary and crystalline rocks. Because the Cretaceous beds are poorly exposed and because all look much alike in this region, no attempt was made during this survey to subdivide the Cretaceous east of the Ocmulgee River.

Some relations, however, have been observed that suggest general conclusions concerning the lithology and stratigraphy of the Cretaceous east of the Ocmulgee River. Toward the east from the Chattahoochee River valley the Cretaceous formations younger than the Tuscaloosa have many of the characteristics of the Tuscaloosa as they show less and less a distinctly marine origin, but certain features of lithology and structure of the Tuscaloosa strata remain distinct. 'The bounding contacts have been traced definitely as far east as Bibb County, and the Eutaw and Tuscaloosa formations have distinctive lithologic characteristics at least that far east. The lithologic characteristics have already been described in the discussions of the various formations, and the structure of the bounding contacts are discussed under "Structure."

The only direct fossil evidence that beds younger than Tuscaloosa extend eastward from the Ocmulgee River, and that kaolin-bearing rocks of east-central Georgia are of post-Tuscaloosa age, was found by Stephenson and Thompson (1943, unpublished report). They found poorly preserved plant remains and scattered particles of resin beneath a green fuller's earth type of clay of Jackson age in a lens of sandy carbonaceous clay within a white kaolinitic clay at the abandoned Martin clay mines, 1 mile south of Gordon, Wilkinson County. In this material R. W. Brown (LaMoreaux, 1946b, p. 44) found fragments of dicotyledenous leaves, unidentified fruits and seeds, and a plant resembling Phyllites asplenoides Berry. The type specimen of this plant was from the Coffee sand-equivalent to the Eutaw formation and the lower part of the Selma chalk-at Coffee Bluff, Hardin County, Tenn., from a bed higher than the beds con- 
taining the rest of the plants that were collected from that formation (Berry, 1919, p. 141). If the identification of the plant from Georgia is correct and if the plant has correlative value, the clay that underlies the Jackson in east-central Georgia is early Selma, or perhaps Eutaw, in age.

In a recent article Kesler $(1951$, p. 3$)$ mentions remains of leaves and grasses in thin beds of lignite that are in beds of brown carbonaceous sand and clay as much as 6 feet thick, in or immediately adjoining a few of the kaolin deposits.

It is hoped that further studies of such material will yield more evidence on the age of the kaolin-bearing beds.

Other evidence that the pre-Tertiary strata of the Coastal Plain in eastern Georgia are younger than the Tuscaloosa formation is afforded by structure (see structure maps, pl. 3). Where structural control was obtained, the formations higher than the Tuscaloosa appear to have a slightly more northerly strike than the Tuscaloosa. The Tuscaloosa is, therefore, gradually overlapped by higher formations in central and eastern Georgia. The definitely traceable horizons trend northeastward toward the clay-producing region east of the Ocmulgee River.

The Ripley formation provides the most reliable data. Although its lithologic character is definitely traceable as far as Houston and Bibb Counties, no bounding contacts were found east of Peach County, and control points for the structure map are necessarily lacking. But the formation definitely trends toward the clay-producing region, and the Halymenites-bearing sands that Stephenson and Thompson found east of the Ocmulgee River are probably in or below the clayproducing rocks of Twiggs County. It seems, therefore, that the clay-producing rocks are Ripley or post-Ripley in age.

White and pale-purple and red variegated clay beds are found throughout eastern Alabama and western Georgia in the Providence sand; not far updip from and east of the definitely marine facies of that formation. White clays of possible minable quality have been found in that formation in western Georgia as far west as Schley County, where they have reportedly been prospected by the U. S. Bureau of Mines. Eastward the Providence sand contains clay lenses as far as the formation has been definitely traced. The Cusseta sand contains commercial clay as far west as Butler, Taylor County, where it has been mined for a number of years (Smith, 1929, p. 66-70). This locality is not far east of the area where the Cusseta is definitely marine. Although the other marine Cretaceous beds are not known to contain minable beds of kaolin, the Eutaw and Blufftown formations have thin lenses of kaolin east of their marine facies, and the Ripley may contain white kaolin lenses east of the area where it is definitely marine. 
In northern Houston County, however, is a white hard brittle clay resting on fine marine sand. Herrick and LeGrand (personal communication) believe it to be of Tertiary age, although it was mapped in some places as Cretaceous by MacNeil (1947). As the commercial white kaolinitic clay of Twiggs County and farther east is consistently just beneath rocks of Jackson age and occurs apparently only where the Jackson formation covers it, there is a possibility that the kaolin deposits of central Georgia are of pre-Jackson Tertiary age. No horizon has yet been found beneath the kaolin, however, that might be regarded as a contact between Tertiary and Cretaceous rocks. Definite decision on determination of the age of the generally pale coarse sands and the white kaolins just below the Jackson bed must wait until more positive evidence is obtained.

\section{TERTIARY FORMATIONS}

Overlying the Providence sand in southwestern Georgia is a residuum of the Clayton formation of Paleocene age. In this area the formation apparently consisted mostly of limestone, the basal beds of which contained coarse sand. Enough clay was also present in the limestone to form, when weathered, a jumbled mass of ferruginous sandy clay that now caps the high cuesta in Quitman and Stewart Counties. As a result of slumping that accompanied leaching processes, white clays and pale sands of the overlying Nanafalia formation are intimately intermixed in places with the residuum of the Clayton formation. MacNeil (1947) found it generally impossible to separate these formations in mapping on the scale of 1 mile to the inch. $\mathrm{He}$ also found that northeastward from the vicinity of Buena Vista, Marion County, the Clayton has been overlapped by sand of the Claiborne group, although some Paleocene and lower Eocene beds appear beneath the Claiborne in downdip localities. In central Georgia, beginning about in Crawford County, the Claiborne strata are in turn overlapped by beds of Jackson age. Less weathered exposures showing the typical relations between these beds are in lime pits on Rich Hill, 6 miles southeast of Knoxville, Crawford County. Here the Jackson consists of fine sand grading downward into green clay containing hard calcareous beds that lie irregularly and sharply on a soft reeflike 25 -foot bed of porous bryozoan limestone (Ocala limestone of Jackson age). Underlying this limestone is 4 feet of calcareous coarse sand, probably of Claiborne age, which in turn rests on Cretaceous clay that is most likely a bed of the Cusseta sand.

About 21/2 miles north of Knoxville, 12 feet of a dark-red sandy residuum caps the hilltop and may represent the basal sand of an outlier of Tertiary strata. The base of the residuum is about 710 feet above sea level; the sand is massive, clayey, and ferruginous, and 
contains scattered subrounded pebbles as much as 1 inch in diameter. It lies unconformably on pale gravelly sand, perhaps of the Eutaw formation, and this lies on purplish-red clay and gravelly sand that rests on crystalline rocks about 70 feet below the base of the probable Tertiary residuum.

East of the Ocmulgee River the Jackson beds, generally weathered to deep-red clay and sand, overlap most of the Cretaceous and lie on crystalline rocks north of the northernmost outcrops of the Cretaceous. At a few places east of the Ocmulgee River, MacNeil (1947) shows that Claiborne beds down the dip lie directly on and overlap the Cretaceous beds, but up the dip are, in turn, overlapped by the Jackson. Such exposures are immediately east of the Ocmulgee River in Twiggs County and at several localities in and near McBean Creek in Richmond and Burke Counties in the eastern part of the State.

\section{STRUCTURE}

The triangular shape of the Cretaceous area of western Georgia reflects chiefly the difference in structure between the Cretaceous and overlying rocks. The top of the crystalline rocks of the Piedmont Upland, on which the Cretaceous rocks were laid down, strikes more easterly and dips more steeply than do the sediments of Tertiary age -overlying the Cretaceous. The area of Cretaceous rocks, therefore, increases in width toward the west and increases in thickness down the dip.

In western Georgia the strike of the surface of the crystalline rocks, on which the basal Coastal Plain rocks lie, swings gradually from N. $77^{\circ} \mathrm{E}$. in the western part of the State to N. $55^{\circ} \mathrm{E}$. in the eastern part (pl. 3). In Bibb County, halfway across the State, it strikes N. $65^{\circ}$ E.

The southeasterly dip of the top of the crystalline basement in the outcrop area increases from 55 to 60 feet per mile in the Chattahoochee River region to about 100 feet per mile in southeastern Talbot County, 30 miles to the east (pl. 3). It maintains this steep dip through Taylor and Crawford Counties, but averages only 70 to 80 feet per mile in Bibb County. Data were not obtained east of Bibb County during this survey, but there is some evidence that dips are considerably more gentle farther to the east.

A short distance down the dip from the outcrop, as shown by subsurface studies, the surface of the crystalline rocks inclines much more steeply toward the south than on the outcrop. This is well indicated by the calculated dips of that surface between outcrops at Columbus, water wells at Fort Benning, and oil exploration wells farther south. In the bed of the Chattahoochee River at Columbus the top of the crystalline rocks is 185 feet above sea level. Herrick (personal com- 
munication) reports the top of the crystalline rocks in a deep well at Edison, 65 miles down the dip, to be 4,912 feet below sea level (fig. 16). In 65 miles, therefore, the surface slopes 5,097 feet, an average of 78 feet to the mile. Since the well may not be directly down the dip, and since there is little control between the outcrop and the well, the actual dip may be considerably greater.

This steep southerly dip in downdip areas, however, becomes more gentle toward the east. Just west of the Ocmulgee River the slope of the crystalline surface averages 69 feet per mile between the out-

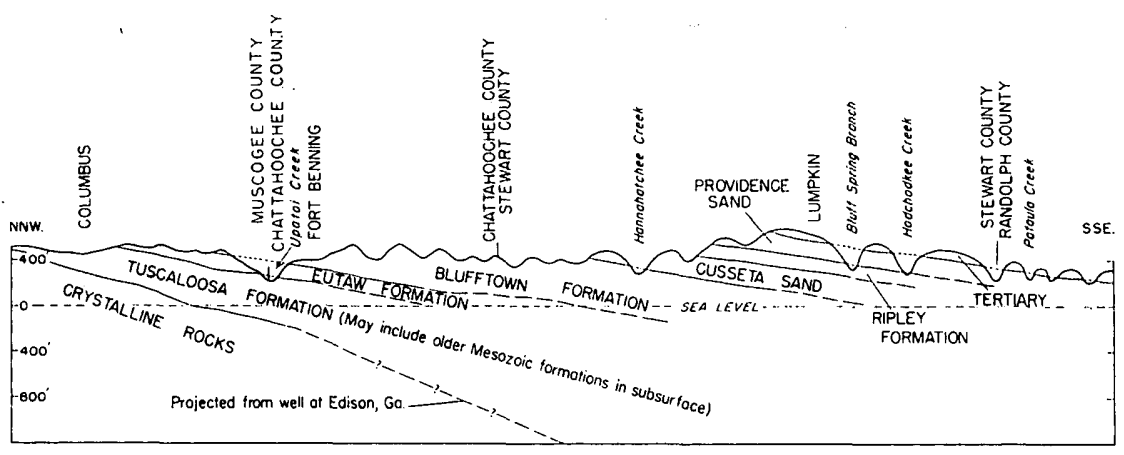
10 MILES

Figure 16.-Generalized profile and structure section, Muscogee to Randolph Counties.

crop and oil test wells 4 miles south of Perry in Houston County (fig. 17). In Washington County, still farther east, LaMoreaux (1946b, p. 40), found that the crystalline surface slopes only about 55 feet per mile in 5 wells drilled for water near Sandersville. Data in his report, however, indicate an average dip of a little less than 35 feet per mile between these wells and the surface outcrop near Carrs Station.

The dip on the surface of the crystalline rocks is greater than that on the top of the Tuscaloosa formation in the outcrop. In the Chattahoochee River region, for example, where the dip on the surface of the crystalline rocks is 55 feet or more to the mile, the dip on top of the Tuscaloosa is only about 40 feet (pl. 3). The thickness of the Tuscaloosa formation thus increases at a rate of about 15 feet per mile in a downdip direction.

Part of the sharply increasing section of basal Cretaceous rocks to the south is considered by geologists who have studied the subsurface geology of this region to be Lower Cretaceous in age. No definite evidence of rocks of that age was found on the surface, although some of the basal Coastal Plain rocks resemble the Vick formation of western Alabama, described by Conant (1946) and considered of preTuscaloosa age. Projection of surface dips into the subsurface sug- 
gests that an angular unconformity separates the Tuscaloosa from the rocks of Lower Cretaceous age, and that the latter wedge out before they reach the surface.

In closely adjoining areas of Alabama, Applin and Applin (1947) have reported Triassic strata below beds of Cretaceous age. In Barbour County, Ala., reddish-brown shales intruded by dark-colored fine-grained igneous rocks were recently observed in well cores from

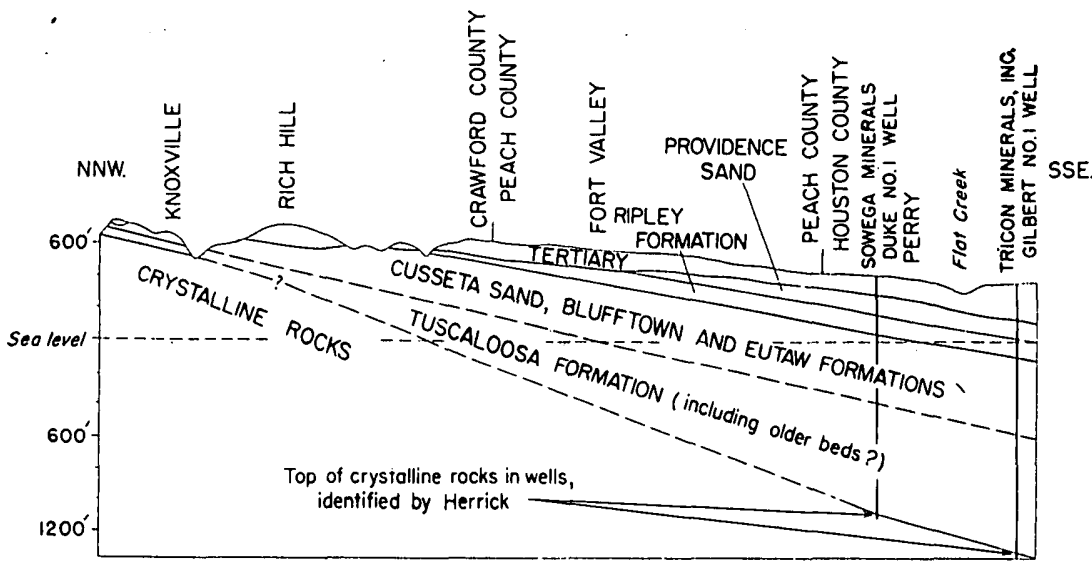

$\circ$

10 MLLES

FIGURE 17.-Generalized profile and structure section, Crawford to Houston Counties.

beds below Cretaceous rocks. It is very likely, therefore, that Lower Cretaceous and even lower Mesozoic rocks occupy in places the interval between the crystalline rocks and the Upper Cretaceous strata.

The dip on top of the Tuscaloosa is to the south-southeast and ranges from about 40 feet per mile in the Chattahoochee Valley to about 33 feet per mile in Taylor and Crawford Counties. The strike of the top of the Tuscaloosa in Chattahoochee Valley is about N. $85^{\circ}$ E., but in eastern Chattahoochee County it swings to a slightly more northerly direction, about N. $70^{\circ} \mathrm{E}$., which it maintains with minor variations to beyond the Flint River.

The structure on top of the Eutaw formation (pl. 3) seems more irregular, and tracing of the contact between the Blufftown and Eutaw was more unsatisfactory than at any other Cretaceous horizon. This is due to the fact that beds of the Blufftown and Eutaw become very similar, and the contact between them could not be traced definitely farther east than north-central Macon County. In the area in which the contact was traceable, however, it seems to maintain a strike of about $\mathrm{N}$. $75^{\circ} \mathrm{E}$.

The top of the Blufftown formation in the Chattahoochee Valley strikes approximately N. $67^{\circ} \mathrm{E} .(\mathrm{pl} .3)$, with minor variation, and 
maintains that strike as far as the Flint River. It dips southeastward a little more than 30 feet per mile, on the average.

Structure contours were not drawn on the top of the Cusseta sand near the Chattahoochee River owing to insufficient control. From eastern Chattahoochee County to the vicinity of the Flint River the contact strikes about N. $60^{\circ} \mathrm{E}$. and dips southeastward 30 to 35 feet per mile.

The top of the Ripley formation in the vicinity of the Chattahoochee River seems to strike about N. $75^{\circ} \mathrm{E}$., but it strikes about N. $60^{\circ}$ E. throughout most of western Georgia. Satisfactory control, however, is lacking over a large area.

The base of the Tertiary rocks in western Stewart County (the top of the Providence sand) trends about N. $75^{\circ}$ E., but in eastern Stewart County it trends about N. $55^{\circ}$ E. In western Macon County the trend of the Tertiary rocks is still more northerly, about N. $50^{\circ} \mathrm{E}$., and in southern Crawford and western Peach Counties they overlap the Providence sand completely. Because of the deep erosion by creeks in eastern Peach and in Houston Counties, the Providence is exposed again as inliers in those counties down the dip from the cuesta front of Tertiary beds.

As Cretaceous rocks were not differentiated into.separate formations beyond the Ocmulgee River, definite dips of individual beds could not be obtained. Scattered reconnaissance observations east of that river, however, suggest that the dip of the top of the crystalline rocks in the subsurface is slightly less than, and that the strike is about the same as, that in the vicinity of Macon. Most of the changes in structure of the Cretaceous rocks occur, therefore, in the general area between the Flint and Ocmulgee Rivers. Most of the rocks west of that area are of a facies and structure similar to that of the East Gulf Coastal Plain, but east of that area they more closely resemble the rocks of the Atlantic Coastal Plain.

The Cretaceous rocks of eastern Alabama and western Georgia that lie above the Tuscaloosa formation are composed mostly of marine beds and strike more easterly than northeasterly, whereas those of eastern Georgia and western South Carolina are mostly lagoonal or nonmarine and strike more northeasterly. The Tuscaloosa is apparently nonmarine and maintains a more easterly strike than overlying formations, at least from western to eastern Georgia.

\section{GEOLOGIC HISTORY AND SUMMARY OF STRATIGRAPHY}

In the Chattahoochee River valley the Tuscaloosa formation comprises the only nonmarine deposits of the Cretaceous. It represents first the deposition of sediments in brackish water or lagoons over a 
land surface of highly decayed crystalline rocks. Much of the sediment was reworked saprolites of the local rocks. The basal conglomerate of the formation is an aggregate of angular vein quartz and resistant. fragments of country rock. This was soon covered with materials deposited mostly in swamps, chiefly sideritic and carbonaceous clay and some lenticular beds of sand.

The next deposits were chiefly coarse sand and rounded quartz pebbles which had been transported a considerable distance. More than 200 feet of this material accumulated and included, near the top of the formation, some carbonaceous and sideritic clays. Weathering has mottled the clays with purplish red, gray, and ocher yellow.

The sea of Eutaw time advanced over these apparently nonmarine sediments. The basal conglomerate of the Eutaw formation consists of reworked pebbles, logs of lignitic wood, shells, and other coarse materials. The beds were extensively bored by Halymenites: Soon, however, and almost abruptly, deposition of very fine sand and clay began. Considerable volcanic material was deposited, along with very-dark-gray clays and thin beds of white sands. Mollusks lived in profusion. Considerable earthquake activity probably occurred, as many of the clays and thin sands have been faulted; the sands were forced into the cracks, resulting in numerous sandstone "dikes." More than 100 feet of this clay accumulated near the end of Eutaw time.

This was followed by deposition of coarse-grained sediments at the beginning of Blufftown time. After several scores of feet of coarse deltaic sands had been laid down, several hundred feet of darkgray marine fossiliferous clays accumulated in a quieter sea. Toward the end of Blufftown time most of the sediment accumulating was fine sand.

The advent of the sea in Cusseta time followed a hiatus in deposition, one of the largest and most significant of the unconformities in the Cretaceous. More than 100 feet of steeply crossbedded marine sand was deposited above a basal conglomerate of reworked shells, phosphate nodules, lignite logs, and any other coarse material that was available for the waves to rework. Down the dip, chocolate-colored laminated montmorillonitic clay was deposited locally. Up the dip and to the east, kaolin clays were deposited in lenticular beds.

The sea in Ripley time, perhaps the deepest and certainly the most extensive of the Cretaceous seas in Georgia, then spread conformably over the Cusseta sand. After moderately deep-water marine sand was deposited, nearly 200 feet of clayey fine sand and calcereous clay was laid down. This was followed by another withdrawal of the sea and break in deposition.

Deposition of Providence sand, mostly of nearby terrestrial origin, began in a shallow sea. The carbonaceous laminated silty fine sand of 
the basal Perote member accumulated first, then nearly 150 feet of coarse deltaic sand was deposited. Down the dip most of the deposits of coarse sand are definitely marine and very fossiliferous, but up the dip only Halymenites major borings indicate that the deposits are nearshore mariné.

Following the deposition of the Providence sand there was perhaps a much longer break than any in the Cretaceous, and an interval of erosion followed. This was followed by the advance of the sea in Paleocene Clayton time in which highly calcareous sediments accumulated.

In the region east of the Chattahoochee River valley nonmarine deposition prevailed during 'Tuscaloosa time. Apparently the water was shallow, for channel and bar deposits are common, and much of the material is crossbedded and coarse. Clays and other fine-grained deposits accumulated mostly during late Tuscaloosa time in shallow lakes and in swamps. Only the upper part of the Tuscaloosa was deposited east of Talbot County in the outcrop area.

Along the east edge of the counties that border the Chattahoochee River, the dark marine clays of both the Eutaw and Blufftown formation interfinger with sands. Farther east most of the formations are sand in which carbonaceous laminated clays form only a small part of each formation. Thus the formations of coarse pale sand and carbonaceous clays can hardly be distinguished from the Tuscaloosa formation, and in earlier surveys the top of that formation was considered to "climb" in the section.

The coarse phase of the Cusseta sand persists to the east. The chocolate clays of the downdip areas are represented east of Marion County by white kaolinitic clays as far west as Taylor County. The deep sea of Ripley time extended farther east than any of the other definitely marine formations, and these marine beds afford the best clue to the stratigraphy of all the Cretaceous deposits in westcentral Georgia.

The Providence sand, which shows evidence of shallow marine origin down the dip in western Georgia, loses these characteristics east of Marion County. Beds of kaolin, however, characteristic of the updip facies of the formation, crop out over extensive areas in west-central Georgia and as far east as the Providence sand is exposed beneath the overlapping Tertiary deposits.

Not only do most of the formations lose their definitely marine characteristics and identity eastward from west-central Georgia, but also the outcropping Cretaceous section becomes appreciably thinner. These conditions persist through western South Carolina, but in eastern South Carolina, in the area of the broad Carolina arch, the formations of Eutaw and Selma age are again distinctly marine. Beneath 
them is the nonmarine arkosic sand and clay formerly called the Middendorf formation, which Cooke (1946, p. 17) has correlated with the Tuscaloosa formation. Cooke, however, states (194.6, p. 17) that it is possible that beds older than the Tuscaloosa may some day be differentiated from these strata in North Carolina and South Carolina.

The east strike of the Tuscaloosa in Georgia, and its disproportionate thinning on the outcrop, together with the very definite evidence of a more gentle dip on the surface of the crystalline rocks in an easterly direction in Georgia, and, in northeastern South Carolina, a strong northeastern strike of apparently correlative rocks, all indicate that a broad low arch on the top of crystalline rocks extends southeastward in eastern Georgia and western South Carolina. The higher Cretaceous rocks that overlapped the Tuscaloosa formation in central Georgia obliterated this arch, or salient, to use Monroe's term for a similar feature in the Upper Cretaceous of Alabama (1941, p. 48). The Upper Cretaceous formations were, in turn, overlapped by the Tertiary formations, and thus the obliteration of the arch or salient which began early in the Cretaceous was complete in Tertiary times. The ridge apparently extended to the coast of southeastern South Carolina.

Down the dip in the subsurface a thick section of the Cretaceous is present, and marine conditions prevailed generally. Even in the Tuscaloosa of southern South Carolina and southeastern Georgia, a part of the section is marine and can be divided into formations somewhat as in western Alabama (Munyan, 1943; Applin and Applin, 1947). Applin and Applin (1947) show by both facies maps and structure contours of middle and early Upper Cretaceous rocks that the strike is easterly as far as the Atlantic Ocean in southern Georgia and South Carolina. This may represent the southern and southwestern flank of the ridge which is indicated in the facies and the structure of the rocks on the surface.

Across this ridge all the Upper Cretaceous formations above the Tuscaloosa were laid down under similar conditions and their: materials were derived from the crystalline rocks of the Piedmont. For these reasons the formations cannot be distinguished. The deposits, which aggregate about 1,200 feet in thickness in the Chattahoochee Valley, are here only 600 feet thick. Part of the thinning of the section results from the overlap of the Tertiary, but part may be due to the lesser amount of deposition across the top of the broad arch. These deposits, mostly of Eutaw and Selma age, represent rapid marine sedimentation. There must have been bays that were deep, quiet, and stable enough to receive white kaolinitic clays without stratification, but elsewhere channel deposits and deltas were being formed. 
Kesler $(1951$, p. 3$)$ has summarized the evidence of environmental conditions under which the sediments in which the clay deposits are found accumulated :

The vast amount of haphazardly piled material in the Tuscaloosa [undifferentiated Cretaceous] indicates rapid erosion and transportation. The debris was evidently deposited in coalescing deltas and alluvial fans along the Cretaceous shore line, and in part redistributed by stream and ocean currents, as shown by an abundance of minor unconformities. The lenses of kaolin were deposited in pools and lakes of fresh or salt water, nearly isolated from the currents.

\section{BIBLIOGRAPHY}

Applin, P. L., and Applin, E. R., 1947, Regional subsurface stratigraphy, structure, and correlation of middle and early Upper Cretaceous rocks in Alabama, Georgia, and north Florida: U. S. Geol. Survey Oil and Gas Inv. Prelim. Chart 26.

Rerry, E. W., 1919, Upper Cretaceous floras of the eastern Gulf region in Tennessee, Mississippi, Alabama, and Georgia: U. S. Geol. Survey Prof. Paper $112,177 \mathrm{p}$.

1923, The age of the supposed Lower Cretaceous of Alabama: Wash. Acad. Sci. Jour., v. 13, no. 20, p. 433-435.

Conant, L. C., 1946, Vick formation of pre-Tuscaloosa age of Alabama Coastal Plain : Am. Assoc. Petroleum Geologists Bull., v. 30, no. 5, p. 711-715.

Cooke, C. W., 1926, Correlation of the basal Cretaceous beds of the Southeastern States : U. S. Geol. Survey Prof. Paper 140-F, p. 137-139.

1936, Geology of the Coastal Plain of South Carolina: U. S. Geol. Survey Bull. 867, 196 p.

_ 1943, Geology of the Coastal Plain of Georgia: U. S. Geol. Survey Bull. $941,121 \mathrm{p}$.

Eargle, D. H., 1950, Geologic map of the Selma group of central and eastern Alabama: U. S. Geol. Survey Oil and Gas Inv. Prelim. Map 105.

Georgia Division of Mines, Mining, and Geology, 1939, Geologic Map of Georgia: Atlanta, Ga.

Goddard, E. N. (chm.), and others, 1948, Rock-color chart: Natl. Research Council, Washington, D. C.

Harris, G. D., 1896, The Midway stage: Bull. Am. Paleontology, v. 1, no. 4, 157 p.

Ferrick, S. M., and LaMoreaux, P. E., 1944, Upper Cretaceous series [of Georgia] : Southeastern Geol. Soc. [Guidebook], Second field trip, p. 6-20.

Hilgard, E. W., 1860, Report on the geology and agriculture of the State of Mississippi : Miss. Geol. Survey, 391 p.

Kesler, T. L., 1951, Occurrence and exploration of Georgia's kaolin deposits: Mining Eng., v. 3, no. 10; and Am. Inst. Min. Met. Eng. Trans., v. 190 [preprint], $7 \mathrm{p}$.

LaMoreaux, P: E., 1946a, Geology of the Coastal Plain of east-central Georgia: Ga. Geol. Survey Bull. 50, pt. 1, 26 p.

- 1946b, Geology and ground-water resources of the coastal plain of eastcentral Georgia: Ga. Geol. Survey Bull. 52, $173 \mathrm{p}$.

Langdon, D. W., 1891, Variations in the Cretaceous and Tertiary strata of Alabama: Geol. Soc. America Bull. 2, p. 587-605.

Lyell, Charles, 1849, A second visit to the United States of North America: New York, $287 \mathrm{p}$.

MacNeil, F. S., 1947, Geologic map of the Tertiary and Quaternary formations of Georgia: U. S. Geol. Survey Oil and Gas Inv. Prelim. Map 72. 
McCallie, S. W., 1903, Sandstone dikes near Columbus, Georgia: Am. Geologist, v. 32 , p. 199-202.

- 1904, [Notes on water resources of] Georgia, in Contributions to the hydrology of Eastern United States: U. S. Geol. Survey Water-Supply Paper 102, p. 207-237.

Monroe, W. H., 1941, Notes on deposits of Selma and Ripley age in Alabama: Ala. Geol. Survey Bull. 48, 150 p.

Monroe, W. H., Conant, L. C., and Eargle, D. H., 1946, Pre-Selma Upper Cretaceous stratigraphy of western Alabama: Am. Assoc. Petroleum Geologists Bull., v. 30, no. 2, p. 187-212.

Munyan, A. C., 1943, Subsurface stratigraphy and lithology of Tuscaloosa formation in southeastern Gulf Coastal Plain : Am. Assoc. Petroleum Geologists Bull., v. 27, no. 5, p. 596-607.

Smith, D. A., and Johnson, L. C., 1887, Tertiary and Cretaceous strata of the Tuscaloosa, Tombigbee, and Alabama Rivers: U. S. Geol. Survey Bull. 43, $189 \mathrm{p}$.

Smith, E. A., Johnson, L. C., and Langdon, D. W., Jr., 1894, Report on the geology of the Coastal Plain of Alabama: Ala. Geol. Survey, $759 \mathrm{p}$.

Smith, L. L., 1931., Solution depressions in sandy sediments of the Coastal Plain in South Carolina: Jour. Geology, v. 39, no. 7, p. 641-652.

Smith, R. W., 1929, Sedimentary kaolins of the Coastal Plain of Georgia: Ga. Geọl. Survey Bull. 44, 482 p.

Spencer, J. W. W., 1.890, "Southern drift" and its agricultural relations: Ga. Agr. Expt. Sta. Bull. 6, p. 90-94.

Stephenson, L. W., 1911, Cretaceous [rocks of the Coastal Plain of Georgia], in Veatch, J. O., and Stephenson, L. W., Preliminary report on the geology of the Coastal Plain of Georgia: Ga. Geol. Survey Bull. 26, p. 66-21.5.

— 1914, Cretaceous deposits of the eastern Gulf region and species of Exogyra from the eastern Gulf region and the Carolinas: U. S. Geol. Survey Prof. Paper 81., $77 \mathrm{p}$.

Stephenson, L. W., and Monroe, W. H., 1.937, Prairie Bluff chalk and Owl Creek formation of eastern Gulf region: Am. Assoc. Petroleum Geologists Bull., v. 21, no. 6 , p. $806-809$.

1938, Stratigraphy of Upper Cretaceous series in Mississippi and Alabama: Am. Assoc. Petroleum Geologists Bull., v. 22, no. 12, p. 1639-1657.

Stephenson, L. W., and Veatch, J. O., 1915, Underground waters of the Coastal Plain of Georgia: U. S. Geol. Survey Water-Supply Paper 341, 539 p.

Thompson, R. M., 1943, Kaolin deposits of Twiggs County, Georgia: U. S. Geol. Survey Strategic Min. Map.

1944, Kaolin deposits of Washington County, Georgia: U. S. Geol. Survey Strategic Min. Map.

Veatch, J. O., 1909, Second report on the clay deposits of Georgia: Ga. Geol. Survey Bull. 18, $453 \mathrm{p}$.

Veatch, J. O., and Stephenson, L. W., 1911, Preliminary report on the geology of the Coastal Plain of Georgia: Ga. Geol. Survey Bull. 26, 466 p..

Warren, W. C., and Thompson, R. M., 1943, Bauxite and kaolin deposits of Wilkinson County, Georgia: U. S. Geol. Survey Strategic Min. Map. 


\section{INDEX}

Acknowledgments

affinis, Nodosaria.

alternata, Dentalina.

americana, Heterostomella

Pullenia

amorpha, Pseudoclavulina

Anomalina clementiana.

nelsoni.

pinguis.

tellinoides

60

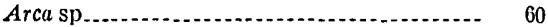

argentaria, Anomia.................. 26, 39, 60, 74

aspera, Clobigerinella....................... 62,63

asplenoides, Phyllites......................... 84

Atlantic Coastal Plain...................... 90

Augusta................. 8

B

Baculites sp.

Baldwinville, section at

Barbour Creek, near Georgetown

Basement rocks, attitude... . 8, 14, 87-88, 90, 92; pl. 3 contacts, Tertiary formations

Tuscaloosa formation exposures................. 11, 12,13,17,20,23,84

basiplanata, Dentalina........................ 61,63

basitorta, Dentalina............................. 61

Bay Gall Creek, near Warner Robins A Ir Base. 82, 83

Bibb County. See formation names.

Bibliography.

94-95

Big Indlan Creek

bilira, Turritella

Black Creek, near Ceneva..................... 17

Black Warrior River........................ 8

Blueville Pond, section near............ 50-51

Blufftown formation, areal extent............. 33 contacts, Cusseta sand _. $38,40,41,42,43,47,48,54$

Eutaw formation......... 25, 26, 27,31, 36, 38 exposures............. 25, 26, 27, 31, 32-43,47,54 geologic history....................... 91,92

lithologic character

local details, Chattahoochee and Muscogee Counties.

$36-40$

Marion County........................ 40-41

Stewart County................... 35-36

Taylor and Talbot Counties.......... 41-43

origin of name............. 62 sections of ........................ 31, 39,42,43

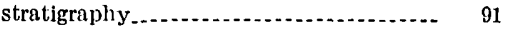

structure........................... 89-90; pl. 3

thickness..................... 35

Bolivinopsis rosula.............. 63

Bonham Creek, at bridge on Hourglass Road $\quad 16$

Box Springs Road, near Cusseta.............. 39-40

Brooklyn.

Pago

Brownsand.................................... 41

Buck Creek, section near. . . . ................. 80-81 valley . . . . . . . . . . . . . . 66,80

Buena Vista_................ 50, 64, 65

Buena Vista Road........................... 13, 27

Bulimina quadrata....................... 61, 63

Bull Creek. ................................. 13, 14

Bullopera sp_.................................... 63

Bustahatchee Creek ................. 46, 58, 75

Butler.................. 19, 31, 41, 42, 45, 51, 53, 65, 85

Byron .............................................. 68

Camp Branch................................. 62

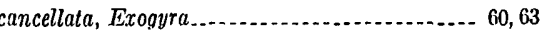

Cardium vaughani......................... 76

sp....

Carolina arch

Carrs Station..................... 88

Ceratobulimina cretacea....... 74

Charing ............. 42,52

Chattahoochee County. See formation names.

Chattahoochee River, Banks Landing....... $\quad 35$

Beton Rocks. ............ 33

Big Bend. 34,37

Broken Arrow Bend................ 15-16, 28

Chimney Bluff........................... 33, 37

Codys Rocks...................... 33

Columbus

Lower Roods Bend.................. 46

Moores Rocks.......... 33

Planter's Landing...................... 37

Race Passes . ......... 37

Slick Bluff ...

Snake Shoals.................... 34, 35

Thompsons Landing $\ldots \ldots \ldots$

Uchee Rapids....................... 27, 28

Woolridge Landing........ 46,47

Chimney Bluff, Chattahoochee River....... 33

Cibicides harperi. . . . . . 61,63

Claiborne group................... 86,87

Claybed 69

Clayton fórmation............. $59,65,77,78,86,92$

clementiana, Anomalina..................... 74

Coffee Bluff, Tenn. ....................... 84

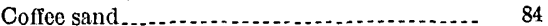

Coffinton

Columbus....................... 11, 12, 13, 14, 16, 87

convexa Gryphaea............................. 58

Cooks Mill Pond, section at................ 16

Cool Creek, near Georgetown................. 58

Cooper Creek, section near Parkhill Cemetery. $\quad 12$

coryelli, Pullenia..................................... 62

costata, Exogyra................... 55, 58,60,61, 73

Cowikee Creek.............................. 46

Crawford County. See formation names.

cretacea, Ceratobulimina.................... 74

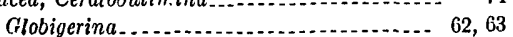


cretacea-Continued

Globotruncana

Ostrea.

Cretaceous rocks, undifferentiated, between the Ocmulgee and Oconee Rivers_ 84-85 undifferentiated, east of the Ocmulgee River 6,84

Cusseta, exposures at. . . . . . . . . . . $34,39,43,48$ section at.

Cusseta sand, areal extent.................. 44 contacts, Blufftown formation .......... 38 ,

$40,41,42,43,47,48,54$

Ripley formation..... 45 $46, \quad 50-51,58,59,65,66,67$

Tertiary formations exposures ... $33,38,40,42,43-54,58,59,65,66,67$ geologic history 91,92 lithologic character.

local details, Bibb County

44-45

Chattahoochee County

Crawford County

Marion County.

Quitman County

Stewart County

Taylor County $50-51$

origin of name.. 46-48

sections of $42,43,48,51,52,59,64,65,66,67,68$ stratigraphy

structure.

thickness

Cuthbert

D

Decatur Bluff, Ala.

Deep Creek

Demopolis chalk -

Dentalina alternata

basiplanata.

basitorta

megalopolitana

pauperata.

vertcbralia

depressa, Cryroidina

Drag Nasty Creek

\section{E}

East Gull Coastal Plain. ... . . . . . . . . . 3, 30 Echeconnee Creek ............... 54, 57, 68, 69

Edison.

Elberta Station, section near

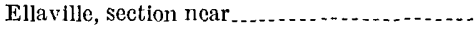

Eoline formation.

Eufaula, A la.

Eutaw. .

contacts, basement rocks.

Blufftown formation..... 25, 26, 27, 31, 36, 38

Tertiary

Tuscaloosa formation . . . . . . $14,16,17,18,19,21,22,26,27,28,29,31$ exposures ....................... $17,18,19,21,23-32,33,36-38,41,84,85,92$ geologic history $91,92,93$ lithologic character. . . . . . . . . . . . . . 2 . 24-25 local details, Chattahoochee County ..... 27-30
Eutaw formation-Continued local details-Continued

Page Crawford and Bibb Counties ....... 31-32 Marion County . . . . . . 30. Muscogee County............... 25-27 Taylor County ................... 31 origin of name............................ 23 sections of . . . stratigraphy ..................... 91 structure. ... . . thickness............................... 25

Exogyra cancellata. . . . . . . . 60,63 costata................ 55, 58,60,61,73, 76 ponderosa........ $32,39,55$ upatoiensis............

\section{F}

falcata, Ostrea .......................... 60, 63 First Division Road ...................... 29, 38

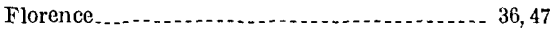

Foraminifera, listed . . ................. 61, 63, 74

Fort Benning, Harmony Church area _. . - $33,38,39$

Hourglass Road. ...................... 39

Lawson Field. . . . . . . .

Marne Road ... . . . . . . . . . . . . . ..... 38

Moye Road. . ........................ 26, 27

Post Cemetery . . ................. 26, 28

post office..................... 28

Sand Hill $\ldots \ldots \ldots$

U. S. Highway $27 \ldots \ldots \ldots \ldots$. . . . 25,27

wells _... 87

Fort Valley .................. $67,69,82$

Frondicularia sp......................... 62, 63

Globulina gidda.............................. 62

Glycymeris sp . . .

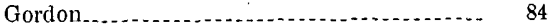

Gryphaea convexa............ 58

mutabilis........................... 58,61

sp_._.

Gumbelina striata............................ 63

Cruttulina sp................................

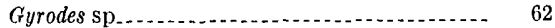

Cyroidina depressa

H

Halymenites - $10,15,19,24,26,27,28,45,55,57,65$, $67,68,69,72,80,81,85,91$ major _- $16,24,29,30,31,34,39,44,47,48,54,56$, $60,63,67,68,77,80,82,92$

Hamulus onyx ........................... 63 sp Hannahatchee Creek..................... 48, 76 Haplophragmoides $\mathrm{sp} \ldots \ldots \ldots$ 
harperi, Cibicides.

Hatcher

Heterosta mella an eriana

Hichitee Creek, near Banks Landing ........ near Planters' Landing.....................

Hodchod kee Creek

Houston County. See formation names.

Houston Lake.

Howard.

I

Ida Vesper.

Indian Creek, section on.

Inoceramus sp...........................

Interior Low Plateaus.

\section{$\mathrm{J}$}

Jackson formation.

86,87

Jacksons Mill, Whitewater Creek .............. Jamestown Road, south of Weems Pond

Junction City

Juniper Creek, exposures on ............. 17, 25, 40 section near.

K

Kinchafoonee Creek

50,80

Kinchafoonec River.

Knoxville, exposures near

sections near.

L

Lagena globosa

Leona.

Lindsey Creek, near Columbus

Linearia metastriata.

Liopistha protexta

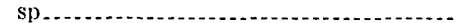

Little Hichitec Creek, along U. S. Highway 280.

Little Patsiliga Creek.

.. 19,31

Loxostoma plaitum

$62,63,74$

Lumpkin, exposures near......... $61,62,70,72,78,79$ Foraminifera listed..................... 61-62 sections near.............................. 60,77

Lynch Road.

\section{M}

McBean Creek

Macon, Clinton St exposures near

Hill St.

Key St.

Neal $A$ ve.

Pionono Road

Rocky Creek Road.

Stanislaus Circle

Macon County. See formation names.

Macon-Reynolds highway

macrodiscus, Robulus.

major, Halyrenites.

Marginulina texasensis

Marion County. See formation names.

Marion-Talbot County line, section on ........

Marshallvillo

Massey Creek

Matthews Church and School
Page

63 Mauk

Page

(

Nor

Mercers Mill Creek, near Georgetown........ $\quad 58$

mesenterica, Ostrea.......................... 60,63

Mesozoic rocks............................ 89

metastriata, Linearia ........................ $\quad 76$

Middendorf formation....................... 8,93

Middle Georgia Pottery, exposure noir....... 9 section near............................ 21

Midway group ............................. 55

Mizell......................................... 42

Mooreville chalk......................... 33

Mossy Creek............................... 67

Moye Road ................................ 27

Muscogee County. See formation names.

musabilis, Gryphaea....................... 58, 61

\section{$\mathrm{N}$}

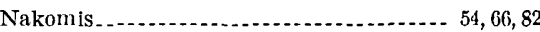

Nanafalia formation ........................... 86

navarroensis, Robulus........................ 63

nelsoni, Anomalina............................ 63

Nodosaria affinis............................ 62, 63

obscura.................................. 62

Northern X.fgnite (Porters Creek clay) ........ 55

obscura, Nodosaria........................... 62

Ocala limestone . ............................ 45,86

Ochillee Creek, near Fort Benning .......... 29

Oconee River.................................. 84

Ohio Station, near Fort Valley . .............. 82

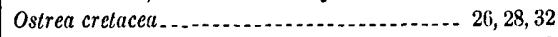

falcala................................... 60,63

mesenterica.................................... 60,63

plumosa.................................. 60

subspatulata................................... 60

tecticos! $a_{\ldots} \ldots$

Owl Creek marl............................... 55

Paranomia scabra............................... 61, 63

Parker's Mill................................ 41

3 Parkhill Cemetery, near Columbus........... 12

Pataula Creek, exposures on ............ 70, 71, 73, 76

Foraminifera listed....................... 74

87 Patsillga Creek........................... 19, 20, 31

22 pauperata, Dentalina.......................... 61, 63

Peach County. See formation names.

22 Pebble Station (near Butler) .................. 53

32 Perry ................................. 57, 60, 73, 82,88

22 Phenix City, Ala.......................... 11, 13

22 Pholadomya sp................................. 61

22 Phyllites asplenoides........................ 84

22 Pino Knot Creek, exposures noar........... 38, 40,41 section near. .............................. 31

20 Pine Mountuin ........................... 17

63 pinguis, Anomalina

63 plaitum, Loxostoma...................... 62, 63,74

62,63 Pleasant Valley School

plumosa, Ostrea

17 ponderosa, Exogyra........................ 32, 39, 55

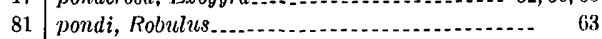

82 Pontotoc Ridge

82 Porifera........................................ 63 


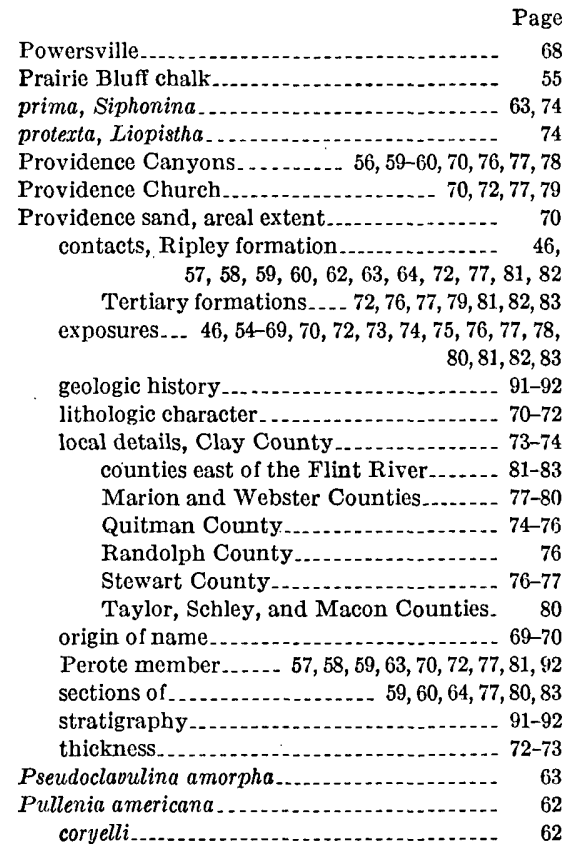

\section{Q}

quadrata, Bulimina

Quarternary deposits, section of.

61,63

\section{$\mathrm{R}$}

Renfroe, exposures near

Foraminifera listed

Renfroe Station, section near.............. 63

Renfroes marl

$43,55,69$

Reynolds, exposures near............... 41, 42, 51; 54 section near.

Rich Hill

45,86

Ripley formation areal extent

55 contacts, Cusseta sand

$46,50-51,58,59,64,65,66,67$

Providence sand .................... 46 , $57,58,59,60,62,63,64,72,77,81,82$

Tertiary formations . . ......... $66,67,68,69$ exposures............... 45, 46, 50-51, 54-69, 70,81 geologic history.

91

Jithologic character. ................... 55-57

local details, Bibb County

69

Chattahoochee County............... 62-64

Craw ford County ................ 66-67

east of the Ocmulgee River........... 69

Houston County .................. 6S-69

Marion County .................. 64

Peach County ....................... 67-68

Quitman County ..................... 57-59

Schley and Macon Counties.......... 66

Stewart County

Taylor County . . .

origin of name . . .

sections of ...- $51,59,60,63,64,65,66,67,68,77,81$ stratigraphy.
Ripley formation areal extent-Continued Page structure $\ldots \ldots \ldots \ldots \ldots \ldots \ldots$ thickness_............................. 57

ripleyensis, Textularia...................... 63

Roberta................... 9, 31

Robulus macrodiscus....................... 63 navarroensis ...................... 63

pondi................................... 63

spisso-costatus.......................... 62, 63

Rocky Creek............................... 22

Rocky Mount Church..................... 59,75

Roods Creek, exposures near ........... 46, 47,76 section near-........ 59

rosula, Bolivinopsis. .......................... 63

Rotten Limestone (Selma chalk) . . . . . . . . . . 54-55

rudita, Gaudryina .......................... 62,63

S

St. Marys Road........................... 14, 26, 27

Sandersville ............................ 88

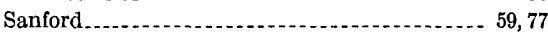

Savannah River............................ 6

scabra, Paranomia ............................. 61, 63

Schatulga Road, exposures on .............. 14, 27

section on................................. 14

Schley County. See formation names.

Selma chalk................. 23, $32,43,84,85,92,93$

Selma group............................ 5, 7,43

Shoal Creek

Siphonina prima

Skipperton.................................. 57,69

Soapstone Creek

spisso-costatus, Robulus. .................... 62, 63

Springvale................................... 76

State Highway 7, near Roberta.......... 31

State Highway 26, at Fort Benning -........... $\quad 50$

near Cusseta... 50

near Ida Vesper........................ 40

near Sanford......................... 59

State Highway 39, near Credilles Mill........ $\quad 73$

State Highway 41, near Buena Vista.......... 17

near Juniper Creek. ...................... 25

section on. ............................... 19,64

State Highway 42, section on ................. 20

State Highway 49, near Fort Valley .......... $\quad 82$

State Highway 96 , near Butler............... 53 section on . . .

State Highway 103 (Columbus-Buena Vista road) ....................... 13, 14, 16, 27

State Highway 128, near Toteover Creek... 66

State Highway 137, near Buena Vista... ..... 50,65 near Butler................................ 53 near Marion-Taylor County line......... 42

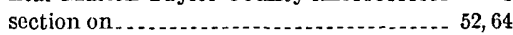

State Highway 247, section on .............. 69

Steam Mill Road, near Columbus......... 14, 15, 27

Stewart County. See formation names.

striata, Gumbelina............................ 63

Structure, determination..................... 6

subspatulata, Ostrea

suturalis, Vaginulina.

\section{$\mathrm{T}$}

Talbot County. See formation names.

Talbotton.................................... 16

Tallapoosa River, Ala......................... 10 
'Taylor County. See formation names.

Tazewell

tecticosta, Ostrea.................................

Tellina sp.

tellinoiles, Anomia.......................... 60,63

T'enth Armored Division Road, section on .... 13

Tertiary formations, exposures................ 21, $45,66,67,68,69,72,76,77,79,81,82,83,84$

contacts, basement rocks

Cretaceous rocks

Cusseta sand

Eutaw formation

Providence sand 21

Ripley formation

Tertiary rocks, east of the Oconee River ...... 84, 87 scetions of ................... 21, $66,67,68,77,83$ structure ............................... 90; pl. 3

tertasensis, Marginulina.................... 62,63

Textularia ripleyensis ........................... 63

Timms Creck ............................... 19, 31

Tobesofkee Creek. . . .

Tolannee Creek.......................... 58

Tombigbee sand ............................... 23, 32, 43

Toteover Creek............................... 66

Triassic strata............................... 89

Trigonia sp............................ 62, 73, 74, 76

trilira, Turritella........................ 61,73,76

Turner Creck. ............................ 76

'Turritella bilira

trilira _..._..................... 61, 73, 76

sp......... 61,62,76

Tuscaloosa formation, areal extent............ $8-9$

contacts, basement rocks. . ...... 11, 12,13,17, 20

Eutaw formation .............. 11, 14, 16, 17, $19,20,21,22,26,27,28,29,31$ cxposures.............. 8-23, 26, 27, 28, 29, 31, 41, 66 geologic history.................... 90-91, 92,94 lithologic character...................... 9-10 local details, Bibb County. . . ............. 22-23

Chattahoochee County ................ 15-16

Crawford County.................... 20-22

Marion County .......... 19

Muscogee County ..................... 11-14

Talbot County....................... 1f

Taylor County....................... 19-20

origin of name..................... 8

sections of .... 12,13,14,16,17, 18,19, 20, 21, 29

stratigraphy .................. 10-11, 90-91

structurc_........... 11, 30,88-89,90,93; pl. 3

thicknoss .......... 11

Twiggs clay.
U

Page

Uchee Creek ................................ 28, 33

Underwood Road, near Columbus............. 16

Unio sp . ................................... 10

Union Chapel ................................. 66

U. S. Highway 19 , exposures on.. $19,20,31,45,53,65$ sections on ........................... 20,65

U. S. Highway 27 , exposures ncar. ........ $28,38,39$ exposures on . . . ........... 14, 16, 25, 26, 40, 48, 60 sections on ............................... 48,60

U. S. Highway 80 , exposures on ..... 12, 13, 10,17, 22 sections on ............................ 13, 17

U. S. Highway 103, near Pine Knot Creek.... 38

U. S. Highway 129, east of Ocmulgee River... 69, 72

U. S. Highway 280, along Little Hichitee Creek............................ 62 near Cusseta. ........................... 49 near intersection with U. S. Highway $27 . . \quad 48$

Upatoi Creek, exposures near ................ 26, 33,36 exposures on .................. 15, 27, 28, 29, 32, 40

McBrides Bridge, fossils described....... $\quad 36$

section on ..................................... 26

upatoiensis, Exogyra............................ 26, 32

Upper Bradley Place.......................... 36

\section{V}

Vaginulina suturalis

webbervillensis............................ 62.63

vaughani, Cardium.......................... 76

Venus sp................................... 60

vertebralia, Dentalina.........................

Vick formation.................................. 88

W

Waltons Mill, section at...................... 68

Warner Robins Air Base _ . . ................... 82, 83

Warrior River................................. 8

webbervillensis, Vaginulina.................... 62,63

Webster County. See formation names.

Weems Pond..................................... 38

Wesley Chapel............................. 67

Whitewater Creek, exposures on............ 21, 22, 53

section on............................... 42

\section{z}

Zenith, exposures near ...................... 54,56,66

section at................................... 66 